INSTITUTO DE PESQUISAS ENERGÉTICAS E NUCLEARES

Autarquia associada a Universidade de São Paulo

\title{
OBTENÇÃO DO CARBONETO DE SILÍCIO PELA REDUÇÃO CARBOTÉRMICA DA SÍLICA
}

JOÃO LUÍS ABEL

Dissertação apresentada como
parte dos requisitos para
obtenção do Grau de Mestre em
Ciências na Área de Tecnologia
Nuclear -Materiais.

Orientador:

Dr. Francisco Ambrozio Filho

São Paulo

2009 


\title{
OBTENÇÃO DO CARBONETO DE SILÍCIO PELA REDUÇÃO CARBOTÉRMICA DA SÍLICA
}

\author{
JOÃO LUÍS ABEL
}

\begin{abstract}
Resumo
$\mathrm{Na}$ escala industrial a obtenção do carboneto de silício (SiC) pela redução carbotérmica da sílica ainda é o meio mais utilizado para sua sintetização. 0 presente estudo visa identificar, de forma comparativa, dentre os redutores comuns como coque de petróleo, negro de fumo, carvão vegetal e grafite o resultado da reação carbotérmica da sílica a partir da turfa. Menciona-se como que a turfa, pode ocorrer na natureza concomitantemente a jazimentos de areias de sílica de elevada pureza, uma das fontes de sílica, destacando que, a proximidade da matéria prima e sua qualidade são, elementos essenciais que determinam os tipos, pureza e custo de produção do SiC. Os ensaios desenvolveram-se a partir de amostras produzidas em forno de resistência elétrica com atmosfera controlada nas temperaturas de $1550^{\circ} \mathrm{C}, 1600^{\circ} \mathrm{C} \mathrm{e}$ $1650^{\circ} \mathrm{C}$, tantos os precursores como os produtos da reação de redução carbotérmica foram caracterizados aplicando-se técnicas de difração de raios $X$, microscopia eletrônica de varredura (MEV) e espectroscopia de energia dispersiva de raios $X$ (EDS). Os resultados evidenciaram a formação do SiC para todos os redutores comuns, bem como para a turfa, mas não foi possível perceber claramente a diferença entre eles, sendo necessário para tanto, ensaios específicos adicionais.
\end{abstract}




\title{
SYNTHESIS OF SILICION CARBIDE BY CARBOTHERMAL REDUCTION OF SILICA
}

\author{
JOÃO LUÍS ABEL
}

\begin{abstract}
The production of silicon carbide $(\mathrm{SiC})$ in an industrial scale still by carbothermal reduction of silica. This study aims to identify, in a comparative way, among the common reducers like petroleum coke, carbon black, charcoal and graphite the carbothermal reduction of silica from the peat. It is shown, that the peat, also occurs in nature together with high purity silica sand deposits, where the proximity of raw materials and their quality are key elements that determine the type, purity and cost of production of SiC. Tests were running from samples produced in the electric resistance furnace with controlled atmosphere at temperatures of $1550^{\circ} \mathrm{C}, 1600^{\circ} \mathrm{C}$ and $1650^{\circ} \mathrm{C}$, both the precursors and products of reaction of carbothermal reduction were characterized by applying techniques of X-ray diffraction, scanning electron microscopy (SEM) and Energy-Dispersive X-ray analysis Spectroscopy (EDS). The results showed the formation of SiC for all common reducers, as well as for peat, but it was not possible to realize clearly the difference between them, being necessary, specific tests.
\end{abstract}




\section{Agradecimentos}

Aos professores Doutores Francisco Ambrozio Filho e Flavio Beneduce Neto, pela orientação e constante estimulo durante o desenvolvimento deste trabalho.

Aos laboratórios de materiais do CCTM do IPEN/USP de pirometalurgia do IPT/USP, materiais do Centro Universitário da FEI e todos os seus colaboradores por permitirem a utilização de sua infra-estrutura no desenvolvimento deste trabalho. 


\section{SUMÁRIO}

$\begin{array}{lll}1 . & 1 N T R O D U C ̧ A ̃ O & 10\end{array}$

1.1. PROCESSOS DE OBTENÇÃO DO SIC

1.2. REDUÇÃO CARBOTÉRMICA PROCESSO ACHENSON 16

1.3. APECTOS TERMODINÂMICOS 20

1.4. ASPECTOS CINÉTICOS 22

2. CONSIDERAÇÕES QUANTO AOS REAGENTES 25

2.1. FONTES DE SÍLICA 25

2.2. FONTES DE CARBONO 28

2.2.1. COQUE DE PETRÓLEO 31

2.2.2. NEGRO DE FUMO 31

2.2.3. GRAFITE 32

2.2.4. CARVÃO VEGETAL 33

2.2.5. TURFA 34

3. OBJETIVO 36

$\begin{array}{lll}\text { 4. PROCEDIMENTOS EXPERIMENTAIS } & 37\end{array}$

4.1. MATERIAIS USADOS COMO REAGENTES 38

4.2. PREPARAÇÃO DOS REAGENTES 47

4.3. ENSAIOS DE REDUÇÃO 48

5. RESULTADOS E DISCUSSÃO 51

6. CONCLUSÕES 60

7. REFERÊNCIAS BIBLIOGRÁFICAS 61 


\section{LISTA DE FIGURAS}

Figura 1.1 - Vista aérea do local do impacto onde foi encontrada a única ocorrência natural do carboneto de silício por Ferdinand Frederick Henri Moissan.

10

Figura 1.2 - Fases do SiC, alguns tipos e suas respectivas formas de empilhamento [fonte : M. Le Flem et al. -HTR 2006, 1-4 oct. 2006, Sandton, South Af ]

11

Figura 1.3 - Amostra de Carboneto de Silício - $\beta$-SiC - obtido pelo processo Acheson [http://araiweb.elcom.nitech.ac.jp/SiC/widegap_e.html].

12

Figura 1.1.1 - Esquema típico de um forno elétrico para produção de SiC.(GUPTA)

16

Figura 1.1.2 - Esquema do processo Acheson para produção de SiC [fonte:W.F. Knippenberg, Philips Res rep. 18, 161-274, March 1963].

17

Figura 1.1.3 - Diagrama de equilíbrio de fases binário $(\mathrm{Si}-\mathrm{C})$ [fonte:Metals Handbook]

18

Figura 1.1.4 - Forno tipo Acheson de resistência em U, pertencente à SICBRAS, localizada na Bahia no Município de Simões Filho.

Figura 1.1.5 - Fluxograma típico do Processo Acheson.

Figura 1.1.6 - Pedra de carboneto de silício preto ( $\alpha$-SiC) [fonte:SICBRAS]

Figura 1.3.1 - Composição química de equilíbrio dos reagentes e produtos em função da relação molar C(s) / SiO2(s)

Figura 1.3.2 - Composição química de equilíbrio dos reagentes e produtos em função da temperatura. 
Figura 2.1.1 - Diagrama de equilíbrio unário das fases da sílica (fonte: www.quartzpage.de)

Figura 2.1.2 - Cristal de Rocha (a), calcedônia (b) e jasper (c). (fonte: www.quartzpage.de)

26

Figura 2.1.3 - Jazida de quartzito (a) e Jazida de areia quartzosa (b) $\quad 27$

Figura 2.2.1 - Diagrama de equilíbrio unário das fases do Carbono. [fonte:BAILAR et al., 1973]

28

Figura 2.2.2 - Estrutura do grafite a ou grafeno (a) e do diamante (b). [fonte:BAILAR et al., 1973]

29

Figura 2.2.3 - Processo de carbonificação (HAENEL, 1992)

30

Figura 2.2.4 - Estrutura cristalina do grafite na forma hexagonal e camadas na seqüência ABA (WISSLER, 2006).

30

Figura 2.2.2.1 - Modelo mostrando a secção de uma partícula esférica de negro de fumo, onde podemos observar a orientação paralela do grafite nas extremidades e perdendo-a em direção ao centro (WISSLER, 2006).

Figura 2.2.3.1. - Imagem de elétrons secundários da estrutura lamelar de um grafite em floco a partir de um microscópio eletrônico de varredura (WISSLER, 2006).

32

Figura 2.2.5.1 - Exemplo de turfa em seu estado natural (fonte: www. commons.wikimedia.org/wiki/File:Peat-bog-Ireland.jpg)

34

Figura 2.2.5.2 - Frente de lavra com destaque a estratigrafia dos sedimentos de turfa, variando de $30 \mathrm{~cm}$ a $1 \mathrm{~m}$ e logo abaixo, areia de sílica

Figura 4.1 - Esquema em blocos dos procedimentos realizados. 
Figura 4.1.1 - Distribuição dos tamanhos das partículas de sílica por granulômetro a Laser.

Figura 4.1.1 - Imagem de elétrons secundários das partículas com clivagem $\mathbf{4 0}$

Figura 4.1.2 - Elementos presentes nas partículas com clivagem da foto 4.1.1 obtidos por EDS

Figura 4.1.3 - Imagem de elétrons secundários das partículas de sílica que apresentam superfície lisa.

Figura 4.1.4 - Imagem de elétrons secundários das partículas do negro de fumo.

Figura 4.1.5 - Imagem de elétrons secundários das partículas do negro de fumo.

42

Figura 4.1.6 - Imagem de elétrons secundários das partículas de turfa. As áreas claras são resultado da ionização dos voláteis presentes nas partículas.

43

Figura 4.1.7 - Imagem de elétrons secundários das partículas do carvão vegetal.

Figura 4.1.8 - Imagem de elétrons secundários das partículas do coque de petróleo

45

Figura 4.1.9 - Imagem de elétrons secundários das partículas de grafite de caráter lamelar

46

Figura 4.2.1 - Recipiente de plástico contendo os corpos de homogeneização (a) e em (b) já com os reagentes pronto para receber o álcool etílico.

47

Figura 4.2.2 - Equipamento de homogeneização, operando por rotação com capacidade de 5 frascos de plástico. 
Figura 4.3.1 - Dimensões do cadinho utilizado no ensaio da redução

Figura 4.3.2 - Esquema em vista isométrica em corte do forno de redução

Figura 4.3.3 - Forno elétrico de atmosfera controlada utilizado nos ensaios

Figura 4.3.4 - Cadinhos de grafite contendo as amostras em seu interior, após o ensaio de redução

50

Figura 5.1 - Variação de perda de massa após a reação de redução para cada fonte de carbono e temperatura do ensaio realizada, comparandose com aquela obtida de forma ideal calculada a partir do carbono fixo, umidade e matéria volátil de cada um dos redutores ou fontes de carbono.

53

Figura 5.2 - Espectros de difração para os produtos de reação para o redutor negro de fumo (NF), grafite (GF), Coque (CQ), carvão vegetal (CV) e turfa (TF) nas temperaturas de $1550{ }^{\circ} \mathrm{C}, 1600^{\circ} \mathrm{C}$ e $1650^{\circ} \mathrm{C}$. (放 $\mathrm{SiC}-\alpha ; \star \mathrm{SiC}-\beta)$.

55

Figura 5.3 - Espectros de difração para os produtos de reação a partir do negro de fumo (NF) após queima a $800{ }^{\circ} \mathrm{C}$ por 4 horas. (放 SiC-a; $\star \mathrm{SiC}$ $\beta)$.

56

Figura 5.4 - Imagem de elétrons secundários dos produtos de reação para cada um dos redutores utilizados.

57

Figura 5.5 - Imagem de elétrons secundários dos produtos de reação para o negro de fumo e grafite.

58

Figura 5.6 - Imagens obtidas por MEV com os elementos presentes no ponto em destaque de cor laranja, para o redutor grafite (GF) e turfa (TF) 


\section{LISTA DE TABELAS}

Tabela 2.2.4.1 - Descrição qualitativa das fases que se apresentam durante a formação do carvão vegetal por pirólise extraído de (BRITO, 1990).

Tabela 4.1.1 - Valores da distribuição dos tamanhos das partículas e seu diâmetro médio.

Tabela 4.1.2 - Teores de Carbono Fixo, Voláteis,Cinzas e Umidade.

Tabela 4.3.1 - Massa inicial de amostra para cada uma das temperaturas dos ensaios.

49

Tabela 5.1 - Massa final de amostra para cada uma das temperaturas dos ensaios.

Tabela 5.2 - Perda de massa em porcentagem por redutor, temperatura e valor médio.

52

Tabela 5.3 - Perda de massa teórico, em porcentagem, por redutor e valor médio real encontrado. 


\section{INTRODUÇÃO}

$\mathrm{O}$ carboneto de silício ( $\mathrm{SiC}$ ) não pertenceu até o final do século $\mathrm{XIX}$, aos materiais que contribuíram para a evolução do homem. Isso é devido a total ausência de cristais de SiC na natureza". A ocorrência "natural" do SiC se deu em 1920, quando Ferdinand Frederick Henri Moissan identificou cristais de SiC em um fragmento de meteorito encontrado na cratera originada por seu impacto denominada "Canion Diablo", no estado do Arizona, EUA (figura 1), cujo mineral recebeu o nome de "Moissanita" em homenagem ao seu descobridor (NASSAU, 2000).

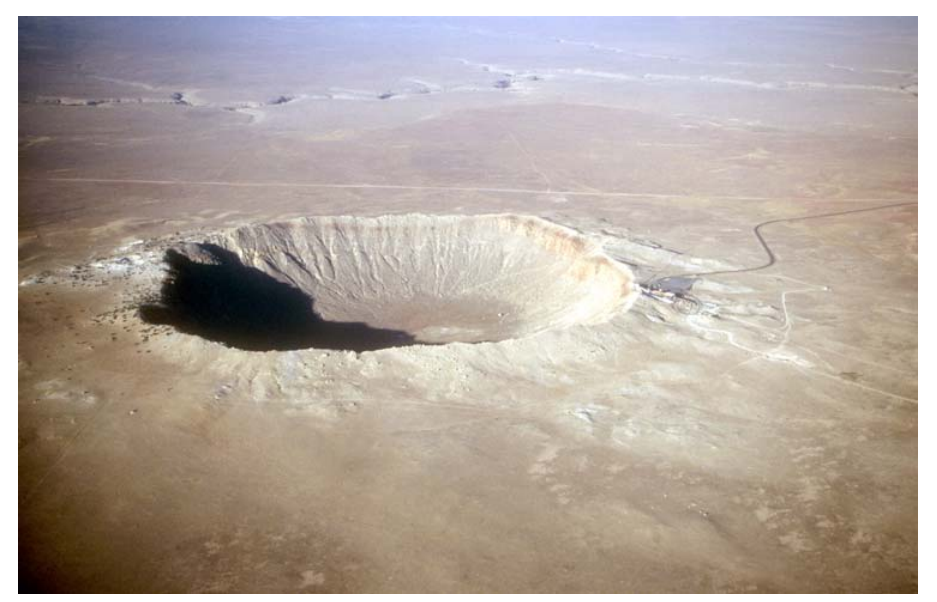

Figura 1 - Vista aérea do local do impacto onde foi encontrada a ocorrência natural do carboneto de silício por Ferdinand Frederick Henri Moissan ${ }^{1}$.

O carboneto de silício foi observado pela primeira vez em 1823 no instituto Karolinska em Estocolmo, Suécia, pelo professor de química Jöns Jacob Berzeliu, que queimando materiais de composição desconhecida observou a presença de um número de átomos de carbono igual aos de silício (MICHAEL SHUR; SERGEY RUMYANTSEV; MICHAEL LEVINSHTEIN, 2006).

Após a invenção do forno elétrico de fusão em 1885 por E. H. \& A. H. Cowles (IZHEVSKYI et al., 2000), Edward Goodrich Acheson sintetizou o carboneto de silício $(\mathrm{SiC})$ utilizando-se de materiais carbonáceos que continham sílica $\left(\mathrm{SiO}_{2}\right)$ em 1892. Seu objetivo era produzir, em escala industrial, um material que substituísse o diamante e outros materiais abrasivos utilizados para corte e polimento. Os produtos cristalinos que Acheson encontrou possuíam grande dureza, refratariedade e não se 
fundiam. Ele deu o nome ao produto de "carborundum" e o descreveu como siliceto de carbono com a composição química $\mathrm{SiC}^{1}$.

A invenção teve grande impacto, e, a partir de então, muitos materiais foram produzidos utilizando-se desse processo, principalmente para a indústria de abrasivos $^{1}$. Em pouco tempo as propriedades eletrônicas do SiC também começaram a ser investigadas, aparecendo o primeiro LED (Light Emitting Diode) elaborado com SiC em $1907^{1}$. O SiC está presente nos dias de hoje isoladamente ou em conjunto com outros materiais devido as suas propriedades físicas, químicas, elétricas e também simplicidade de sua composição, integrando materiais estruturais, refratários e elétricos de alto desempenho.

O SiC apresenta-se no mercado, de maneira geral, como material granulado com tamanhos de partículas que variam de submicron até alguns milímetros, onde a pureza e as fases presentes dependem do tipo e eficiência do processo de obtenção.

$\mathrm{O} \mathrm{SiC}$ é tanto polimórfico quanto politípico. Existe nas formas de $\alpha$-SiC com 18 tipos hexagonais e 23 romboédricos e como $\beta$-SiC, é cúbico e possui a estrutura da esfalarita ou pseudo-diamante. A figura 1.2 apresenta exemplos de alguns politipos da fase $\alpha$ e $o$ da fase $\beta$ com as respectivas notações de empilhamento $(A B C)$ e Ramsdell. O carboneto de silício mais comum é o $\alpha$-SiC conhecido como carborundum, de estrutura atômica hexagonal, é negro, irradiando verde ou púrpura (figura 1.3) (BAILAR et al., 1973).

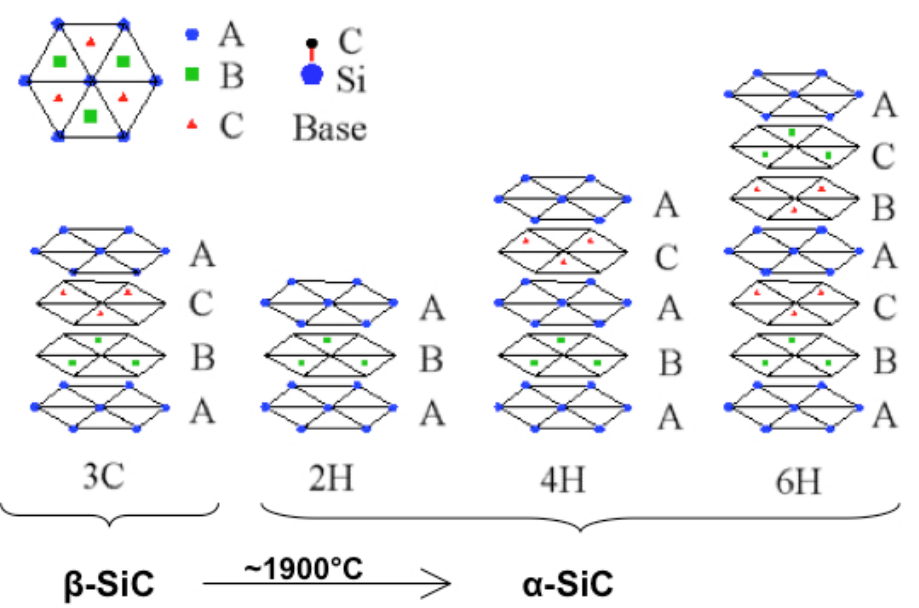

Figura 1.2 - Fases do SiC, alguns tipos e suas respectivas formas de empilhamento. [fonte : M. Le Flem et al. - HTR 2006, 1- 4 oct. 2006, Sandton, South Af] 


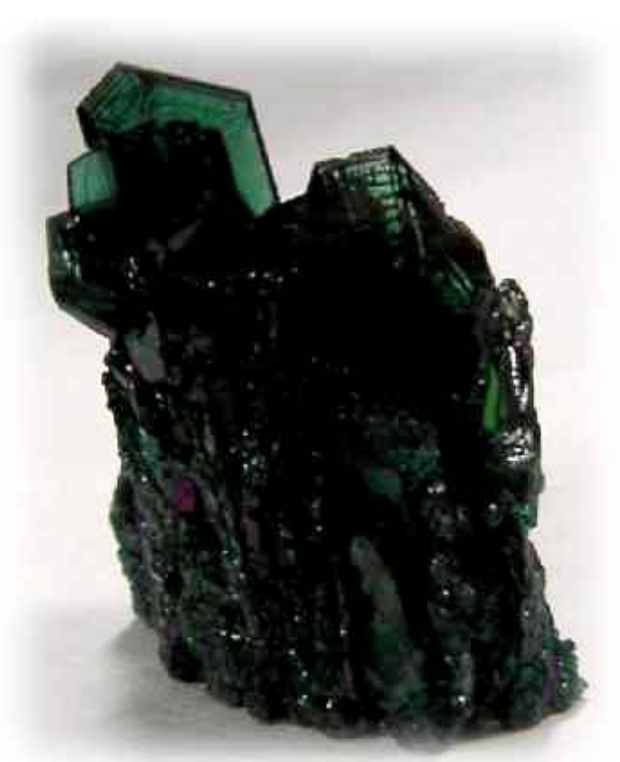

Figura 1.3 - Amostra de Carboneto de Silício - $\beta$-SiC - obtido pelo processo Acheson [http://araiweb.elcom.nitech.ac.jp/SiC/widegap_e.html].

O carboneto de silício é um material de dureza elevada, na escala de Mohs ele alcança 9,25 (diamante 10), alto índice de refração de 2,6 a 2,7 (diamante pouco menos de 2,42), alta condutividade térmica, aproximadamente $5\left(\mathrm{~W} \cdot \mathrm{cm}^{-1} \cdot \mathrm{K}^{-1}\right)$ e boa inércia química. Como semicondutor pode operar em altas temperaturas, ou seja, acima de $600^{\circ} \mathrm{C}$ (dispositivos de silício têm sua temperatura de trabalho abaixo de $300^{\circ} \mathrm{C}$ ), altas freqüências, altas voltagens e em ambientes quimicamente agressivos (PERIC et al., 2003).

O carboneto de silício é reconhecido como material base para as aplicações em cerâmicas estruturais justamente pela combinação de propriedades como: excelente resistência à oxidação, elevada refratariedade, elevada resistência ao desgaste, boa condutividade térmica e resistência ao choque térmico. A combinação destas propriedades se deve ao fato de existir grande quantidade de ligações covalentes (acima de 88\%) entre os átomos de Si e C (IZHEVSKYI et al., 2000).

Os processos de obtenção do SiC e seu tipos, variam em função de seu uso ou aplicação, os quais podem ser por redução carbotérmica, reação direta entre o silício e o carbono no estado sólido, reações em fase vapor e outros melhor descritos no item 1.1. A indústria utiliza-se em maior escala da redução carbotérmica, mais especificamente do processo de Acheson para obtenção do SiC, gerando grandes quantidades de produtos destinados ao setor de abrasivos, refratários e siderurgia, onde essa participação representa mais de $95 \%$ da produção mundial (GUPTA et al., 2001). 
No processo definido por Acheson, ao final do ciclo de produção, têm-se um produto com teores entre 50 e $99 \%$ de SiC cristalizado. A taxa de cristalização e a composição química das matérias primas, que para o caso devem ser uma fonte de $\mathrm{SiO}_{2}$ de elevada pureza $(>99,5 \%)$ e carbono de baixo teor de enxofre, usualmente petro-coque ou carvão vegetal ou antracito, são os responsáveis por definir os tipos de carboneto de silício produzidos e conseqüentemente o valor agregado destes produtos e suas aplicações industriais (SILVA, 2003). O processo Acheson apresenta baixa eficiência, porque apenas cerca de 10 a 15\% da carga (sílica e carbono) é convertida em SiC (GUPTA et al., 2001).

A produção global em 2007 de todas as variedades de SiC é estimada em 1.238.000 toneladas por ano (tpa). A China, considerada como um bloco de produtores é responsável por $56 \%$ desse total sendo a maior produtora mundial. Os outros países com destaque na produção são: Brasil (65.000 tpa), Holanda (50.000 tpa), Venezuela (41.000 tpa), Rússia (40.000 tpa), Noruega (40.000 tpa), Estados Unidos (38.000tpa), Ucrânia (32.500 tpa), Japão (30.000 tpa), México (20.000 tpa), Polônia (20.000 tpa) e Espanha (10.000 tpa). No Brasil, a unidade da Saint-Gobain Materiais Cerâmicos em Barbacena, Minas Gerais, é a maior produtora mundial individual, responsável pela fabricação de 60.000 tpa de SiC (SILVA, 2003; HARRIS, 2008).

A oferta mundial de carboneto de silício cresceu nos últimos dez anos, fortalecida pelo uso disseminado desse produto. As expectativas futuras para este mercado no Brasil e no mundo são animadoras. Para o setor de refratários esperase estabilidade ou um pequeno crescimento. No ramo de abrasivos, o crescimento esperado é maior, especialmente no setor de super-abrasivos, onde são comercializados pequenos volumes a um alto valor agregado (SILVA, 2003).

Entretanto, o grande crescimento previsto será para o mercado de cerâmicas avançadas, especialmente na indústria eletrônica que emprega exclusivamente o SiC-verde ou $\beta$-SiC , onde o ramo de semi-condutores e áreas correlatas vem crescendo. O setor de compósitos metalúrgicos a base de $\mathrm{SiC}$ tem também expectativas de crescimento, uma vez que novas fronteiras já estão abertas para aplicações de alta tecnologia, tais como: filtros para motores a combustão, blindagens contra armas de fogo e peças de intenso desgaste nas indústrias mecânica e automobilística (SILVA, 2003). 
Atualmente, de forma global, os preços de diversas matérias primas e produtos, sofrem constantes alinhamentos em seus custos a fim de adaptarem-se as situações de mercado, impostas por mudanças na área ambiental, energética, econômica e social. Para o caso do carboneto de silício não é diferente, principalmente por ser um produto que depende de grande quantidade de energia, fontes de carbono e quartzo de elevada pureza, que pelas peculiaridades de cada um dos processos de obtenção dessas matérias primas, interferem significativamente no meio ambiente.

É importante ressaltar que a qualidade do carboneto de silício produzido pela redução carbotérmica, como já mencionado, está relacionada com o teor de sílica do minério empregado bem como seu redutor. Assim encontram-se na natureza reservas de sílica de elevado teor como nos quartzitos e jazidas de lascas de quartzo (cristal de rocha). Esses minérios ocorrem de forma heterogênea em seus jazimentos o que leva o minerador a explorá-lo por garimpagem também conhecido como "catação", que implica em muitos casos, em grande impacto ambiental.

Com o rigor crescente da legislação ambiental, esses métodos de lavra estão sendo restringidos a algumas áreas implicando em aumento de preço do minério de sílica, por conta do transporte e beneficiamento diferenciado. Tal situação impulsiona o estudo e a busca por novas fontes e melhoria nos processos de extração e beneficiamento das jazidas já existentes, como o caso apresentado pelo pesquisado Arthur Jarbas Cardoso da Silva, em sua dissertação de mestrado, apresentada em 2003, sob o título - "CARACTERIZAÇÃO TECNOLÓGICA DO QUARTZITO FRIÁVEL DE ITUTINGA - MG, COM VISTA À PRODUÇÃO DE CARBETO DE SILÍCIO (SIC)" - que teve como objetivo a ampliação das reservas do quartzito de maior pureza daquela jazida (SILVA, 2003).

As fontes de carbono ou redutores para o processo Acheson passam pela mesma situação de busca por alternativas, uma vez que o coque de petróleo tem seu preço em função do mercado mundial, o que em determinados momentos pode inviabilizar a comercialização do SiC, por concorrer com outros produtores que se utilizam do carvão mineral como o antracito, que em alguns casos estão, também, próximos da unidade de produção. 
A turfa, objeto deste estudo, pode ser uma alternativa de redutor, uma vez que em alguns jazimentos de sílica ela ocorre concomitantemente a esta, apresentando-se em camada superior ao minério de quartzo.

\subsection{PROCESSOS DE OBTENÇÃO DO SiC}

O SiC, como já mencionado, apresenta duas fases, alfa e beta, e dentre elas diversos tipos e conseqüente variação em suas aplicações. Essa variedade proporciona a existência de diferentes rotas de processo para a sua obtenção que dependem do custo e aplicação do produto final.

Os processos de obtenção do SiC dividem-se em dois: aqueles que produzem grandes quantidades de SiC de composição química, fases e morfologia variadas, necessitando das etapas de refino, moagem e classificação; e os processos que visam obter o SiC na sua forma mais pura, com fase, morfologia e tamanho de partícula definidos.

Segundo Chen, Sem-Hua e Lin, Chun-I (1998) existem basicamente 4 métodos principais utilizados na obtenção do SiC, denominados: (i) carbonização direta, (ii) deposição química por vaporização (iii) método "sol-gel" e (iv) redução carbotérmica.

Os três primeiros são mais utilizados para obtenção de SiC em partículas finas (submicron) de elevada pureza a partir de reagentes puros, o que torna esses processos caros, quando comparado com a redução carbotérmica que utiliza fontes de baixa pureza de sílica e carbono como reagentes, elementos de fácil aquisição e baixo preço (LIN, YUNG-JEN; TSANG, CHIA-PING; 2003).

O processo de carbonização direta tem como seus reagentes o silício ( $\mathrm{Si}$ ) e o carbono $(\mathrm{C})$ no estado sólido apresentando-se eficiente quanto a energia necessária para obtenção do $\mathrm{SiC}$, bem como quanto sua pureza. Isso é devido a reação ocorrer a partir de reagentes puros, o que gera $\mathrm{SiC}$ de fase $\beta$ com granulometria fina ideal para o processo de sinterização como esclarece Satapathy et al., (2005), ou ainda por moagem de alta energia onde o Si misturado com grafite produz partículas finas de $\beta$-SiC (CHAIRA, D.; MISHRA, B.; SANGAL, 2007).

Os processos como "Chemical Vapor Deposition" (CVD) - deposição química por vapor - a partir do silano, e "sol-gel" a partir de alcóxidos de Si visam obter 
também SiC de elevada pureza, diferentes morfologias e cristalografias para aplicações específicas.

A redução carbotérmica é o método mais utilizado tanto para produzir pequenas (miligramas) como para grandes quantidades (toneladas) de $\mathrm{SiC}$, variando sua pureza, polimorfismo e politipismo em função da matéria prima, temperatura, atmosfera e sistema de aquecimento. Segundo Yung-Jen Lin e Chia-Ping Tsang (2003), o mecanismo comumente aceito na formação do SiC é a reação gás-sólido entre o $\mathrm{SiO}_{(\mathrm{g})}$ e o $\mathrm{C}_{(\mathrm{s})}$, pois quando a $\mathrm{SiO}_{2}$ em contato com o $\mathrm{C}$ está sendo reduzida, o $\mathrm{SiO}_{(\mathrm{g})}$ é um produto intermediário na produção do SiC. A formação do SiC é afetada pela área de contado e o grau de mistura entre a sílica e o carbono, indicando que o carbono é constituinte decisivo na síntese do SiC por redução carbotérmica.

\subsection{REDUÇÃO CARBOTÉRMICA - PROCESSO ACHESON -}

Gupta et al., descreve o processo a partir de um forno a resistência, onde a carga, constituída da mistura de uma fonte de sílica com outra de carbono, é inicialmente disposta até a altura dos eletrodos e em seguida, unindo esses, é depositado e compactado sobre a carga, o grafite, que atuará como resistência, fazendo-se a seguir a cobertura com restante da carga que compõem-se também de material semi-convertido proveniente de operações anteriores, para atuarem, inclusive, como refratário, totalizando corridas da ordem de 125 toneladas (NASSAU, 2000).

Na figura 1.1.1 é apresentado um desenho esquemático de forno típico do processo.

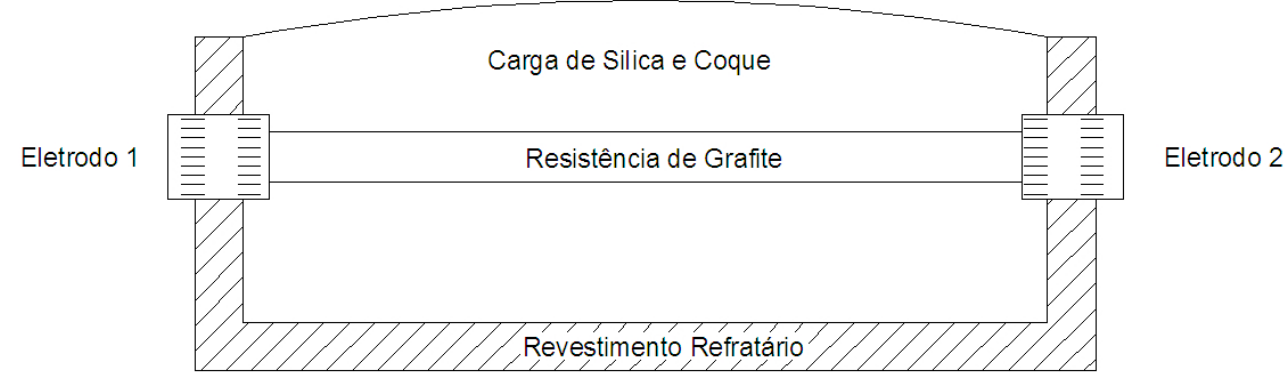

Figura 1.1.1 - Esquema típico de um forno elétrico para produção de SiC (GUPTA). 
O calor é gerado pela resistência de grafite que é atravessada por grande quantidade de corrente elétrica, favorecendo a síntese do SiC segundo a reação:

$$
\mathrm{SiO}_{2}(\mathrm{~s})+3 \mathrm{C}(\mathrm{s}) \longrightarrow \mathrm{SiC}(\mathrm{s})+2 \mathrm{CO}(\mathrm{g})
$$

Sendo continuamente fornecido pelo eletrodo, o calor é transferido através da carga, do centro à parte externa, onde este alcança temperaturas da ordem de $2.000^{\circ} \mathrm{C}$ à $2.700^{\circ} \mathrm{C}$, as quais dependem dos coeficientes de transferência de calor dos materiais, aditivos que compõem a mistura, e dos gases gerados durante a reação de redução.

A seguir é mostrado na figura 1.1.2 um esboço do processo Acheson.

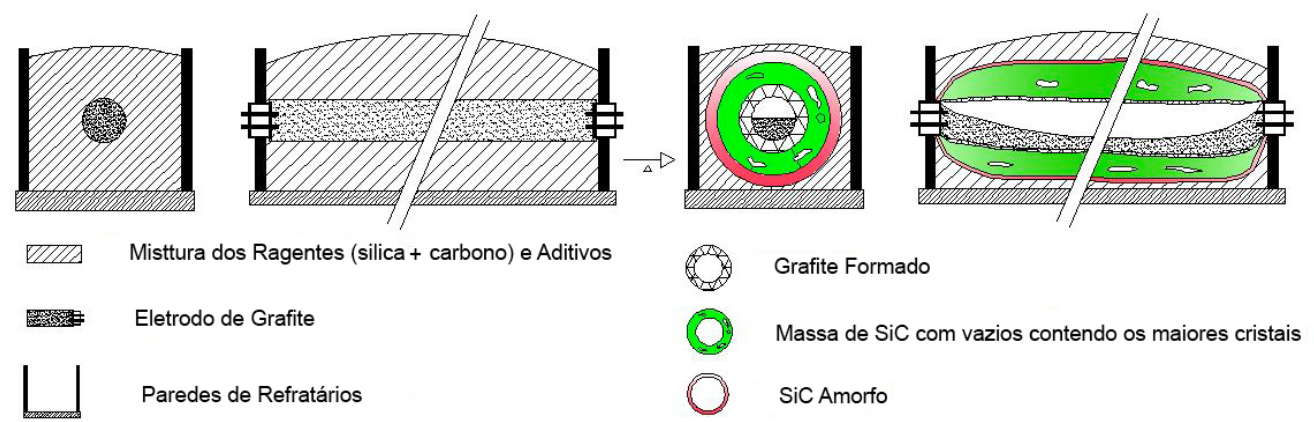

Figura 1.1.2 - Esquema do processo Acheson para produção de SiC [fonte: W.F. Knippenberg, Philips Res rep. 18, 161-274, March 1963].

Quando a temperatura no centro alcança $1.500^{\circ} \mathrm{C}$ ou mais, várias reações começam a ocorrer a fim de se obter o $\mathrm{SiC}$. O $\mathrm{CO}(\mathrm{g})$ produzido conforme a reação (1) é queimado no topo da carga, mantendo-se o forno em operação por mais de 40 horas.

No diagrama de equilíbrio $\mathrm{Si}-\mathrm{C}$ da figura 1.1.3 são apresentadas as fases que surgem com a variação da composição e temperatura. 


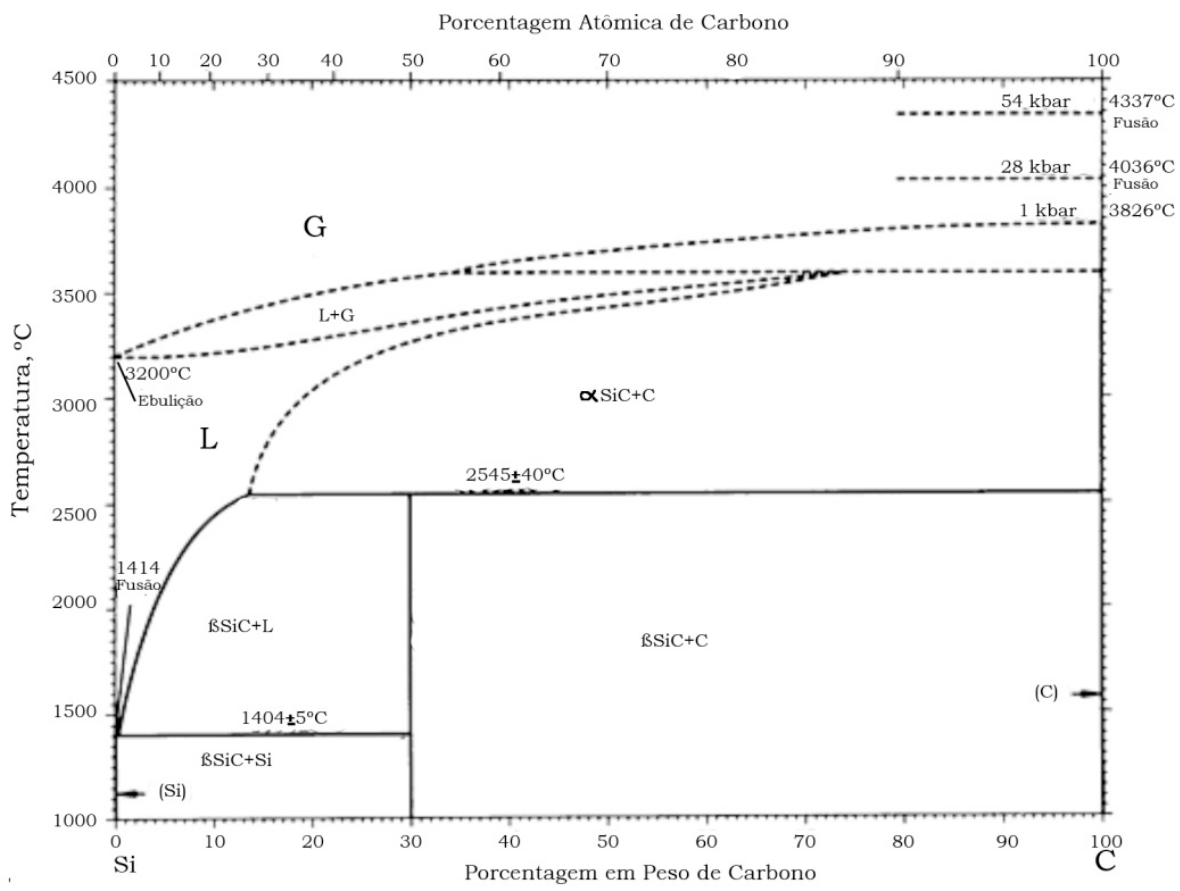

Figura 1.1.3 - Diagrama de equilíbrio de fases binário ( $\mathrm{Si}-\mathrm{C})$ [fonte:Metals Handbook]

Na figura 1.1.4 observa-se um forno de resistência em $U$, onde o que se vê é o SiC que envolve a resistência de grafite, ficando evidenciada a quantidade de material semi-reagido retirada, pois, com carga completa quando do inicio da operação, o anodo e catodo, destacados na cor laranja, estão inteiramente cobertos.

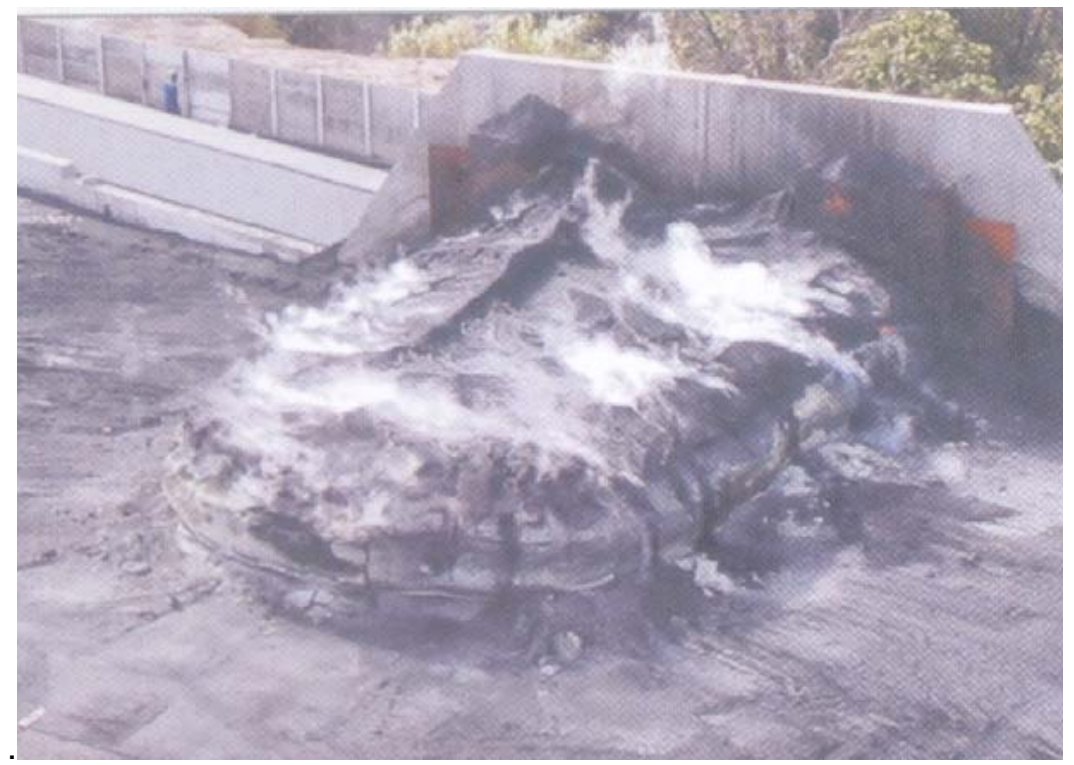

Figura 1.1.4 - Forno tipo Acheson de resistência em U, pertencente à SICBRAS, localizada na Bahia no Município de Simões Filho. 
Teoricamente a energia necessária para se produzir SiC a partir da sílica e de carbono é de $2,2 \mathrm{kWh} / \mathrm{kg}$, entretanto, a indústria utiliza atualmente de 6 a $12 \mathrm{kWh}$ por quilograma de SiC produzido (GUPTA et al., 2001).

No processo Acheson, como citado acima, são produzidos dois tipos de carbonetos de silício, quais sejam, $\alpha-S i C$ e $\beta-S i C$ resultantes após aquecimento da carga entre $1.200^{\circ} \mathrm{C}$ a $2.400^{\circ} \mathrm{C}$, moagem, classificação, refino ou lavagem para retirada de impurezas, e por último secagem (CHAIRA et al., 2007), como se depreende do fluxograma do processo apresentado na figura 1.1.5. Os aditivos constituem-se de sal ( $\mathrm{NaCl})$ e serragem, sendo o primeiro para eliminar impurezas pela formação de voláteis resultantes da reação com o cloro, e o segundo (serragem), que após sua queima cria na carga caminhos preferenciais para escoamento dessas impurezas na forma de gás, bem como possibilita a migração de monóxido de carbono e o monóxido de silício pela carga, favorecendo a produção do carboneto de silício.

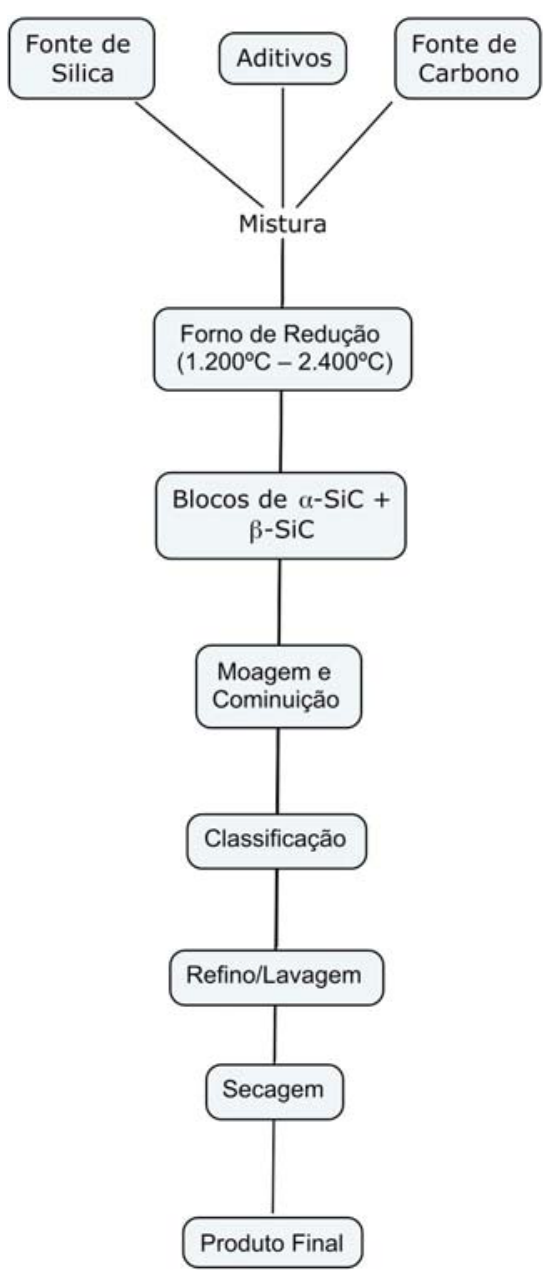

Figura 1.1.5 - Fluxograma típico do Processo Acheson. 
O carboneto de silício produzido apresenta impurezas que em função de seus teores definem sua aplicação em refratários, processos metalúrgicos, abrasivos e sinterizados. Esses elementos geralmente são $\mathrm{Si}, \mathrm{SiO}_{2}, \mathrm{C}, \mathrm{Al}$ e $\mathrm{Fe}$ (SOMIYA, S.; INOMATA, Y., 1991).

Em visita à planta industrial da SICBRAS em Simão Filho, na Bahia, foi possível observar como ocorre o processo de produção do carboneto de silício pelo processo Acheson e seus produtos resultantes da moagem, classificação e lavagem. A figura 1.1.6 mostra uma pedra de carboneto de silício preto ( $\alpha-\mathrm{SiC}$ ) retirada após o ciclo de aquecimento e resfriamento do forno, onde se evidencia os canais formados pelo escoamento de gases gerados durante o processo de redução.

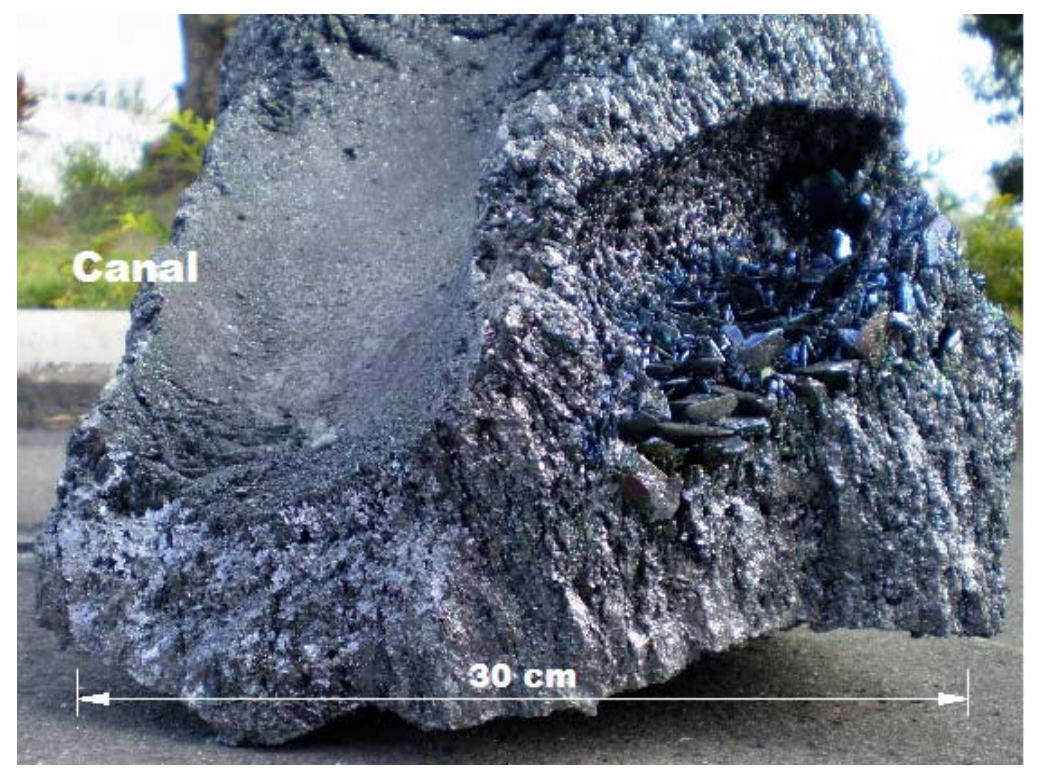

Figura 1.1.6 - Pedra de carboneto de silício preto ( $\alpha-S i C)$ [fonte:SICBRAS].

\subsection{APECTOS TERMODINÂMICOS}

Segundo Gupta et al. (2001), é complexa a reação para formação do SiC, pois envolve muitos fenômenos físicos e químicos como: vaporização, condensação, decomposição e recristalização.

A obtenção do SiC ocorre pela reação descrita a seguir, a qual vem sendo estudada intensamente.

$$
\mathrm{SiO}_{2}(\mathrm{~s})+3 \mathrm{C}(\mathrm{s}) \longrightarrow \mathrm{SiC}(\mathrm{s})+2 \mathrm{CO}(\mathrm{g})
$$

Os três estágios descritos a seguir representam o mecanismo mais razoável pelo qual ocorre o processo de redução: 
- Estágio Inicial

$$
\mathrm{SiO}_{2}(\mathrm{~s})+\mathrm{C}(\mathrm{s}) \longrightarrow \mathrm{SiO}(\mathrm{g})+\mathrm{CO}(\mathrm{g})
$$

- Estágio de Propagação

$$
\begin{array}{lll}
2 \mathrm{C}(\mathrm{s})+\mathrm{SiO}(\mathrm{g}) & \longrightarrow \mathrm{SiC}(\mathrm{s})+\mathrm{CO}(\mathrm{g}) \\
\mathrm{SiO}_{2}(\mathrm{~s})+\mathrm{CO}(\mathrm{g}) & \longrightarrow \mathrm{SiO}(\mathrm{g})+\mathrm{CO}_{2}(\mathrm{~g}) \\
\mathrm{C}(\mathrm{s})+\mathrm{CO}_{2}(\mathrm{~g}) & \longrightarrow 2 \mathrm{CO}(\mathrm{g})
\end{array}
$$

\section{- Estágio Final}

O estágio final é aquele em que todo carbono $(\mathrm{C})$ ou sílica $\left(\mathrm{SiO}_{2}\right)$ são consumidos pelas reações (2) a (5) (CHEN et al., 2000).

A análise termodinâmica efetuada com o auxílio do programa FactSAGE 5.5 revela as fases em equilíbrio da reação. A partir do cálculo da energia livre de Gibbs, para cada fase individualmente, foram obtidas as fases em equilíbrio. A figura 1.3.1 apresenta as composições em equilíbrio em função da relação molar $\mathrm{C}(\mathrm{s}) / \mathrm{SiO}_{2}(\mathrm{~s})$ para uma temperatura de $1.600^{\circ} \mathrm{C}$.

Temp $=1.600^{\circ} \mathrm{C}$

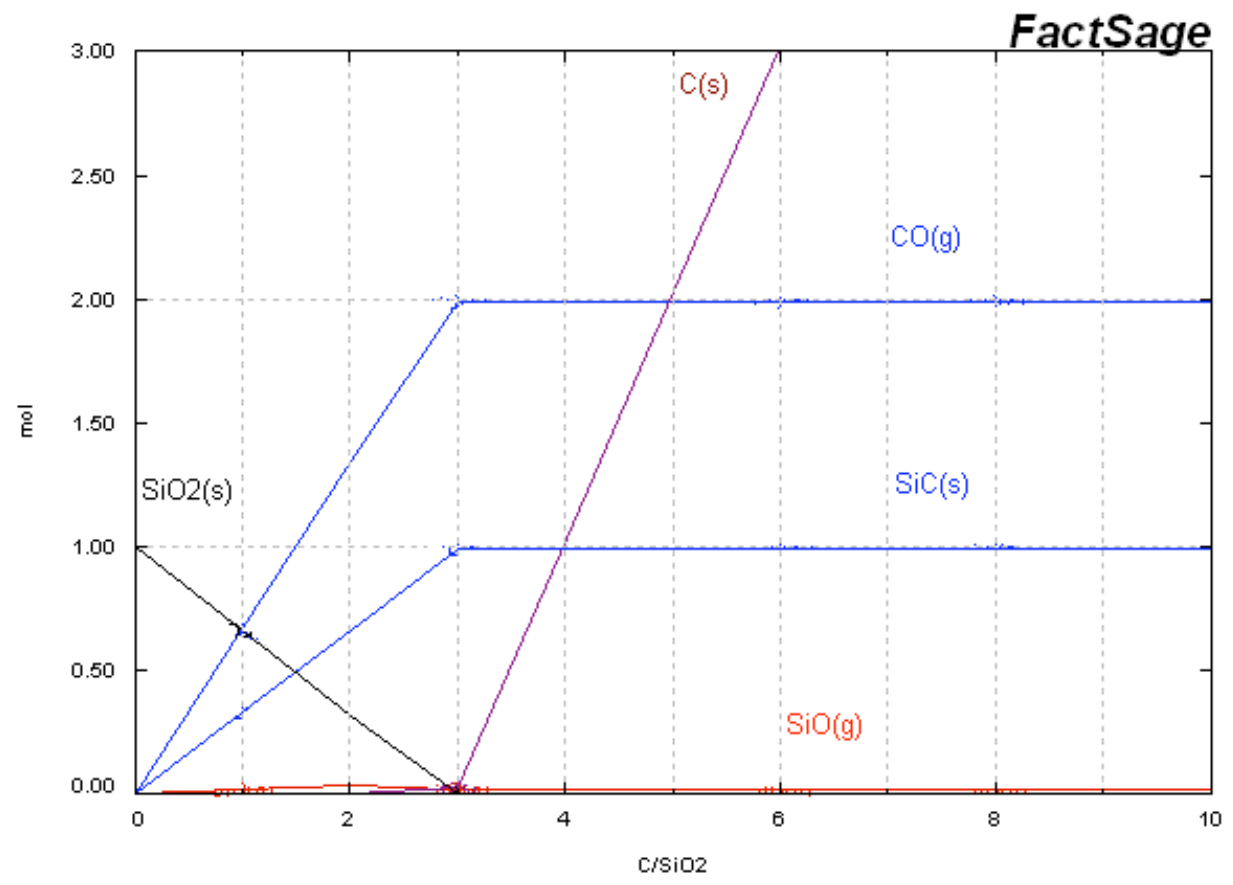

Figura 1.3.1 - Composição química de equilíbrio dos reagentes e produtos em função da relação molar $\mathrm{C}(\mathrm{s}) / \mathrm{SiO}_{2}$ (s). 
Pode-se depreender da figura 1.3.1 que o valor ideal da relação molar é maior ou igual a 3 , onde a presença de $\mathrm{SiO}(\mathrm{g})$ é mínima, e os produtos de reação $\mathrm{CO}(\mathrm{g})$ e $\mathrm{SiC}(\mathrm{s})$ são estáveis.

A seguir a figura 1.3.2 apresenta o diagrama da composição de equilíbrio dos reagentes e produtos da reação de redução para a relação molar fixa de $\mathrm{SiO}_{2} / \mathrm{C}(\mathrm{s})$ igual a $1 / 3$ e pressão igual a 1 atmosfera. Fica evidenciado que a formação do $\mathrm{SiC}(\mathrm{s})$ inicia-se a uma temperatura de aproximadamente $1.512^{\circ} \mathrm{C}$ e, portanto acima de $1.515^{\circ} \mathrm{C}$ as fases estáveis presentes são $\mathrm{CO}(\mathrm{g})$ e $\operatorname{SiC}(\mathrm{s})$.

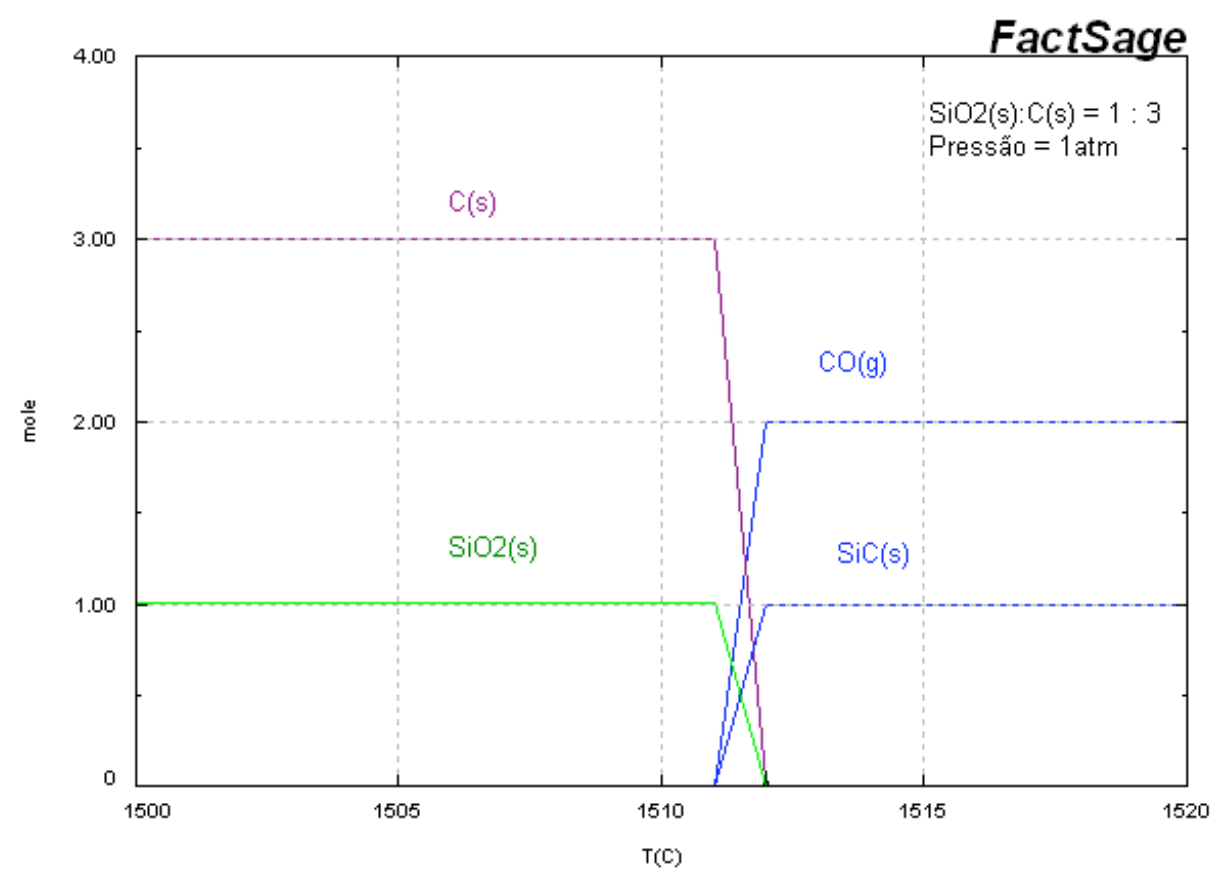

Figura 1.3.2 - Composição química de equilíbrio dos reagentes e produtos em função da temperatura.

\subsection{ASPECTOS CINÉTICOS}

Chen et al. (1997), esclarecem que a reação sólido-sólido (2) -estágio inicial- é de curta duração, uma vez que, não existindo mais contato entre o C e o $\mathrm{SiO}_{2}$ a reação pára. No estágio de propagação pode-se desprezar sua velocidade quando comparada com as reações gás-sólido (3) a (5), que permanecem por longo período até que todo sólido $\mathrm{C}$ ou $\mathrm{SiO}_{2}$ seja consumido.

A área de contato entre os reagentes, antes de iniciar a reação, é importante pois determina o tempo de duração da reação. O SiO e o CO nesse caso estão em quantidade suficiente para consumir toda o sílica ou carbono restantes. 
O $\mathrm{SiO}(\mathrm{g})$ é um produto intermediário, produzido enquanto a $\mathrm{SiO}_{2}(\mathrm{~s})$ está em contato com o $\mathrm{C}(\mathrm{s})$ e sendo reduzida por este. Por conseqüência a continuidade na formação do $\mathrm{SiC}(\mathrm{s})$ é afetada pela área de contato e eficiência na mistura entre o $\mathrm{SiO}_{2}(\mathrm{~s})$ e o $\mathrm{C}(\mathrm{s})$.

Em Romero, F.J. N., Reinoso, F. R. e Diez, M.A., (1999), reitera-se que o maior problema do processo de redução carbotérmica é o tamanho das partículas dos reagentes pela necessidade de maior área de contato entre eles, pois como já exposto, uma vez que a sílica se decompôs em SiO a formação de carboneto de silício é controlada pela difusão do SiO na estrutura do carbono.

Assim, é senso comum que, o tipo de fonte de carbono que se pretende usar como constituinte durante a síntese carbotérmica do SiC é decisivo na eficiência com que será produzido, ou seja, o carbono demonstra influência substancial na morfologia e tamanho das partículas SiC produzidas (LIN et al., 2003).

Chen, C. Y., Lin C. I. e Chen S. H. (2000), estudam a cinética da obtenção do $\mathrm{SiC}$ analisando, em escala laboratorial, os efeitos da vazão de gás inerte, o qual observa que, quanto maior a vazão do gás inerte mais lenta se torna a reação. $E$ explica que a razão para tanto, é que quando a vazão de gás inerte aumenta a transferência de massa através da fina película de gás no entorno dos reagentes também aumenta. Assim os gases, produzidos pelas reações do estágio inicial e de propagação como o $\mathrm{SiO}(\mathrm{g}), \mathrm{CO}(\mathrm{g})$ e $\mathrm{CO}_{2}(\mathrm{~g})$, são facilmente removidos para fora da matriz sólida e conseqüentemente a reação diminui sua velocidade e rendimento. Analisa também os efeitos na reação de redução relativos a altura do corpo de prova, relação molar $\mathrm{SiO}_{2} / \mathrm{C}$, tamanho da partícula da sílica e do carbono e a densidade aparente, descritos a seguir.

\section{- Efeito da altura do corpo de prova}

O efeito da altura do corpo de prova atua no sentido de que quanto maior, maior será o rendimento da produção de SiC. Quando a amostra é alta, maior é a dificuldade dos gases $\mathrm{SiO}(\mathrm{g})$ e $\mathrm{CO}(\mathrm{g})$ em se difundirem para fora, permanecendo dentro da amostra o que implica no favorecimento e aceleração das reações (3) a (5). 


\section{- Efeito da temperatura}

Chen, C. Y., Lin C. I. e Chen S. H. (2000) esclarecem que quanto maior, a temperatura maior será a taxa de produção de SiCo, e ressaltam que, quando a temperatura está abaixo de $1.300^{\circ} \mathrm{C}$ a produção de SiC é baixa.

\section{- Efeito da relação molar}

Quanto à relação molar $\mathrm{SiO}_{2} / \mathrm{C}$ na produção do $\mathrm{SiC}$, os autores apresentam graficamente que quanto menor essa relação mais rápida é a reação, porém seu rendimento $\left(\mathrm{SiC}_{\text {(produtos) }} / \mathrm{SiO}_{2 \text { (reagentes) }}\right)$ é menor, e este aumenta significativamente para relações molares a partir de $1 / 3$, mantendo-se praticamente estável para valores maiores que $1 / 3$.

\section{- Efeito do tamanho de partícula}

Chen, C. Y., Lin C. I. e Chen S. H. (2000) observam que este efeito é significativo no sentido de acelerar a reação quando as partículas diminuem seu tamanho até valores de $68 \mu \mathrm{m}$, tanto para a sílica como para o carbono. Para partículas menores que $68 \mu \mathrm{m}$ o efeito não foi significativo.

\section{- Efeito da densidade da amostra}

Expõem ainda que quanto maior a densidade, menor o rendimento da reação, pois quanto maior os pontos de contato entre a sílica e o carbono, é favorecida a reação sólido-sólido entre a sílica e o carbono definida como sendo a reação no estágio inicial de velocidade baixa, assim quanto menor a densidade melhor o rendimento pois são favorecidas as reações de propagação sólido-gás.

Chen C. Y., Lin C. I. e Chen S. H. (2000), esclarecem que para aumentar o rendimento da reação de produção do SiC, é necessário aumentar o tamanho da amostra e diminuir: densidade, fluxo de gás inerte, tamanho de partícula, tanto da sílica como do carbono e relação molar $\mathrm{SiO}_{2} / \mathrm{C}$. Elementos como o óxido de ferro também aumentaram a velocidade da reação atuando como catalisador. 


\section{CONSIDERAÇÕES QUANTO AOS REAGENTES}

As especificações químicas e físicas exigidas das matérias primas ou reagentes empregados na fabricação do $\mathrm{SiC}$, não são as mesmas para os diversos fabricantes de SiC.

Dependendo dos teores dos contaminantes nas matérias primas, principalmente alumínio e ferro, podem ser obtidos cristais de SiC-verde da fase $\beta$, ou SiC-preto da fase $\alpha$, sendo que a produção da variedade verde somente é possível a partir de matérias-primas mais puras (SILVA, 2003).

Observa-se que, a qualidade de matéria prima e o controle do processo são elementos essenciais na obtenção de SiC e seus diferentes tipos, bem como sua influência no consumo de energia.

Um dos maiores problemas do processo de redução carbotérmica é o tamanho das partículas dos reagentes, determinantes no sentido de favorecer o maior número de pontos de contato entre elas, objetivando o favorecimento da reação sólido-sólido. Com o objetivo de reduzir esses problemas, não é surpresa que muito se tem feito em buscar alternativas entre os reagentes, principalmente os materiais que são fontes de carbono, a fim de melhorar, de forma geral, a eficiência na produção do SiC (ROMERO et al., 1999).

Existem vários trabalhos que tratam do uso de diferentes fontes de $\mathrm{SiO}_{2}(\mathrm{~s})$ e C(s), na síntese do SiC, tais como: CHEN et al. (1997, 1998, 2000), LIN et al. (2003), CATTAMANCHI (1998), ROMERO et al. (1999), AGARWAL et al. (1999), SATAPHATY et al. (2005) e em destaque SUJIROTE et al. (2003), que utiliza casca de arroz como fonte simultânea de $\mathrm{SiO}_{2}$ e $\mathbf{C}$, e ainda SELVAM, A., NAIR, N. G. e SINGH, PARAMANAND (1998), que utilizam casca de côco para produzir nano fibras de SiC. Todos visam melhorar, alterando as fontes das matérias primas principalmente do $\mathrm{C}$ - as variáveis termodinâmicas e cinéticas para obtenção do SiC de composição e morfologia controladas.

\subsection{FONTES DE SÍLICA}

A sílica ocorre na natureza sob várias formas ou fases; na forma cristalina conhecida como quartzo, tridimita e cristobalita; como não cristalina variando o grau 
de hidratação, variedades criptocristalinas (cristais ocultos - microcristais) e algumas vezes como sílica vítrea.

Na figura 2.1.1 são apresentadas as condições de temperatura e pressão em que as fases da sílica são estáveis.

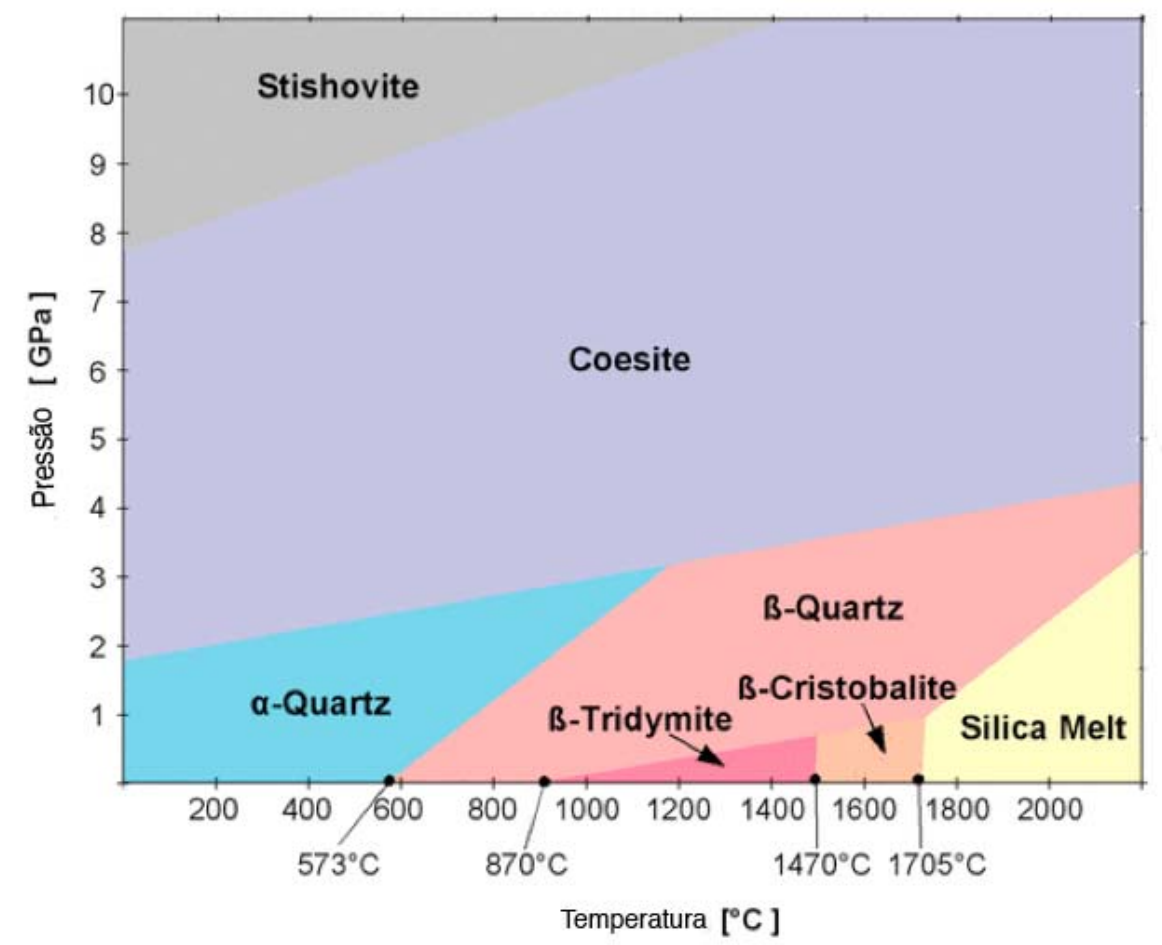

Figura 2.1.1 - Diagrama de equilíbrio unário das fases da sílica [fonte: www.quartzpage.de]

A forma mais conhecida e natural do quartzo (cristalina) é o cristal de rocha, quartzo rosa, ametista, citrino e quartzo fumê. Na figura 2.1.2 são apresentados alguns exemplos dessas formas.

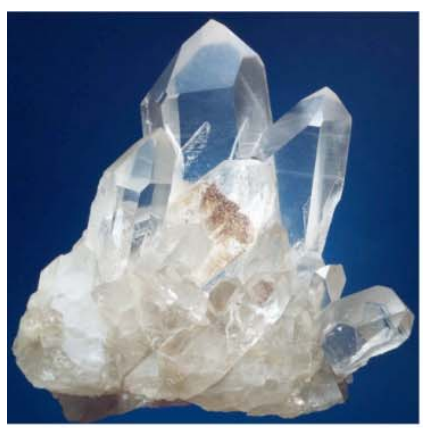

a)

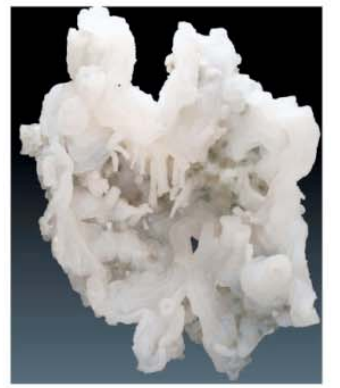

b)

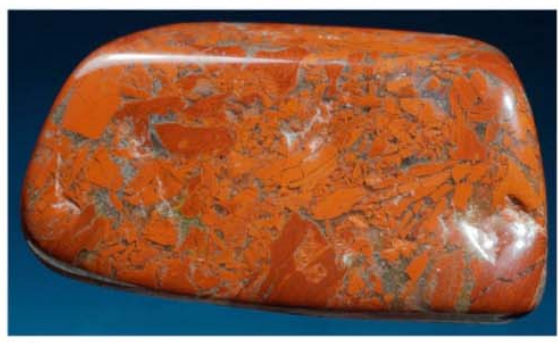

c)

Figura 2.1.2 - Cristal de Rocha (a), calcedônia (b) e jasper (c). [fonte: www.quartzpage.de]

As variedades criptocristalinas mais comuns são a calcedônia, carneliana, ágata, ônix, jasper e sílex (figura 2.1.2). O quartzo também é o maior constituinte do 
granito, dos quartzitos, das areias de quartzo e arenitos como exemplificado na figura 2.1.2. Para o quartzo amorfo hidratado temos as opalas, terras infusoriais e terras diatomáceas que apresentam a sílica hidratada e outros minerais resultantes da decomposição das rochas, conchas calcárias e algas, depositados em um mesmo local.

A forma vítrea mais interessante é um material de alta densidade conhecido como coesita (figura 2.1.1), formada sob elevada pressão, onde a forma vítrea comum é a obsediana (BAILAR, 1973).

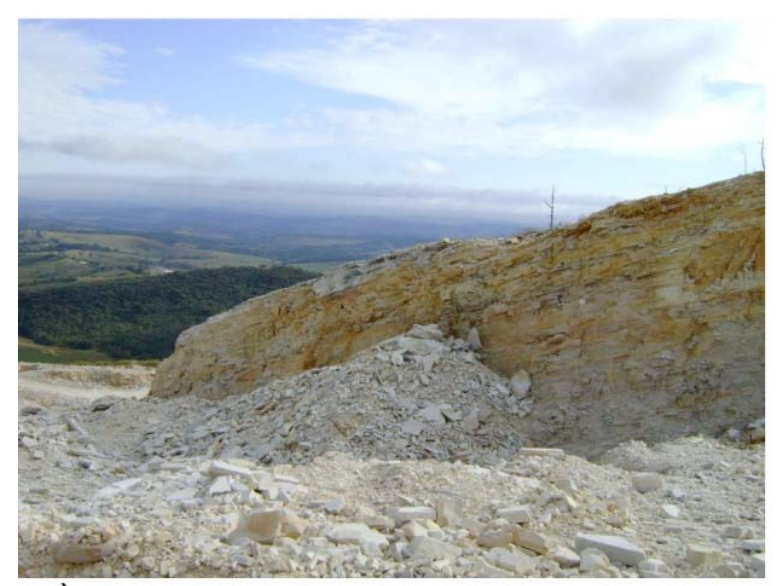

a)

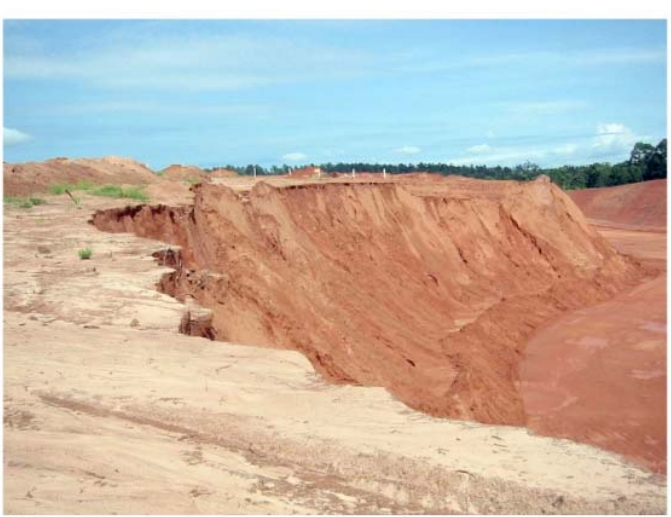

b)

Figura 2.1.3 - Jazida de quartzito (a) e Jazida de areia quartzosa (b)

As fontes mais puras de sílica são aquelas provenientes de jazidas de cristal de rocha que em meio a outros minerais ou solos encontram-se sob a forma de veios.

Essas fontes, quando comparadas às jazidas de areais de sílica e quartzitos mostradas na figura 2.1.3, são em menor número na natureza e apresentam elevado preço devido ao método de extração ser mais caro para o cristal de rocha.

Na produção em escala industrial do carboneto de silício, utiliza-se o minério de sílica de alta pureza e com tamanho de partículas maiores que 150 micras, podendo chegar até alguns centímetros. Isso implica na necessidade de beneficiamento desses minérios a fim de obter teores de sílica maiores que $99,5 \%$ e tamanhos de partículas adequadas ao processo de redução. $O$ custo desse minério é em função do tipo de jazida, localização e do processo de extração, seja para jazidas de cristal de rocha, quartzito ou areia quartzosa. 


\subsection{FONTES DE CARBONO}

O carbono ocorre sob as formas conhecidas como: diamante, grafite, negro de fumo, coque, carbono ativado, fulerenos, nanotubos, fibras e etc. (WISSLER, 2006). Suas formas alotrópicas são basicamente duas: hexagonal e romboedral sendo a última correspondente ao diamante e a hexagonal conhecida como grafeno, constituinte das formas restantes.

A figura 2.2.1 mostra o diagrama de fase do carbono e a figura 2.2.2 as células unitárias do grafeno (grafite) e do diamante (BAILAR et al., 1973).

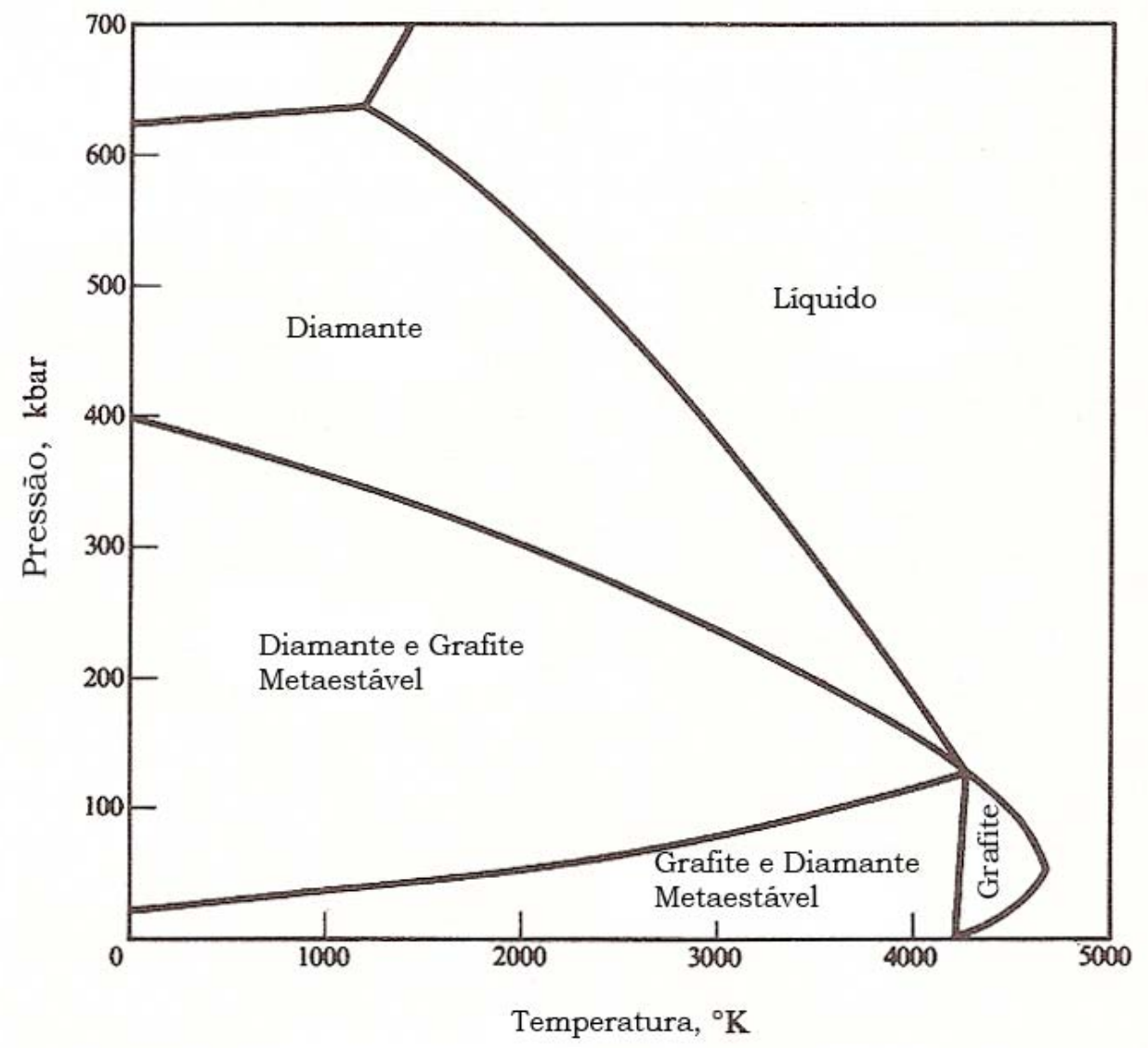

Figura 2.2.1 - Diagrama de equilíbrio unário das fases do Carbono [fonte: BAILAR et al., 1973]. 
a)

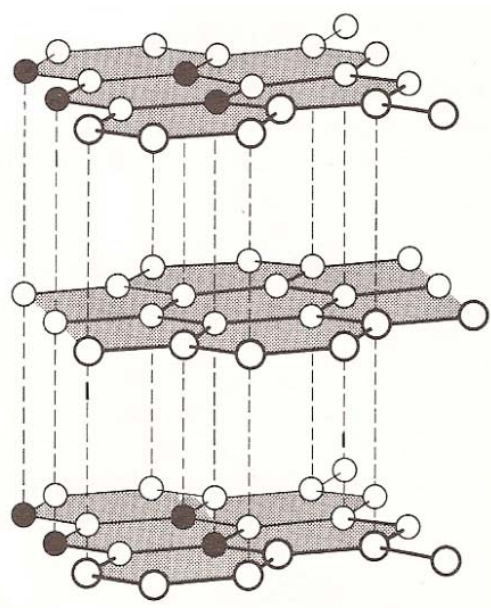

b)

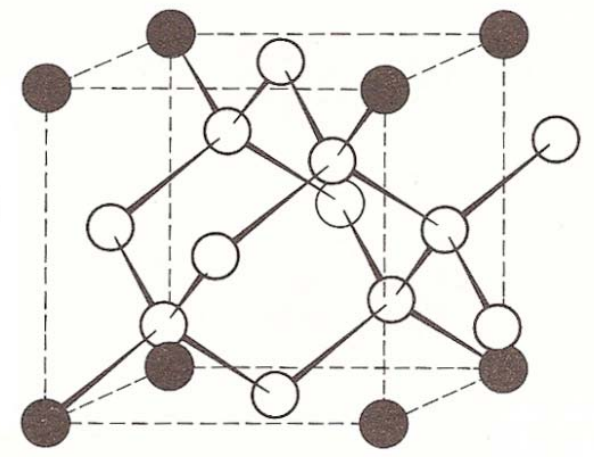

Limites da célula unitária

Figura 2.2.2 - Estrutura do grafite $\alpha$ ou grafeno (a) e do diamante (b) [fonte: BAILAR et al., 1973].

As várias formas do carbono são decorrentes de processo artificial ou natural, este último conhecido como carbonificação, que descrito de forma simples é o processo em que o material vegetal, no seu ciclo vital, deposita-se no solo e por constante decomposição, transforma-se seqüencialmente em TURFA, LINHITO, HULHA e finalmente ANTRACITO. Isto define a série evolutiva do carvão mineral, sendo a turfa o menos carbonificado e o antracito o mais carbonificado e por último o GRAFITE que é carbono puro (grafeno), que em condições ambientais mais críticas o grafeno - hexagonal - ganha a forma romboedral (diamante).

A figura 2.2.3 a seguir esquematiza o processo de carbonificação, mostrando que ele depende da pressão exercida pela movimentação natural do solo superficial e movimentos tectônicos do subsolo. 


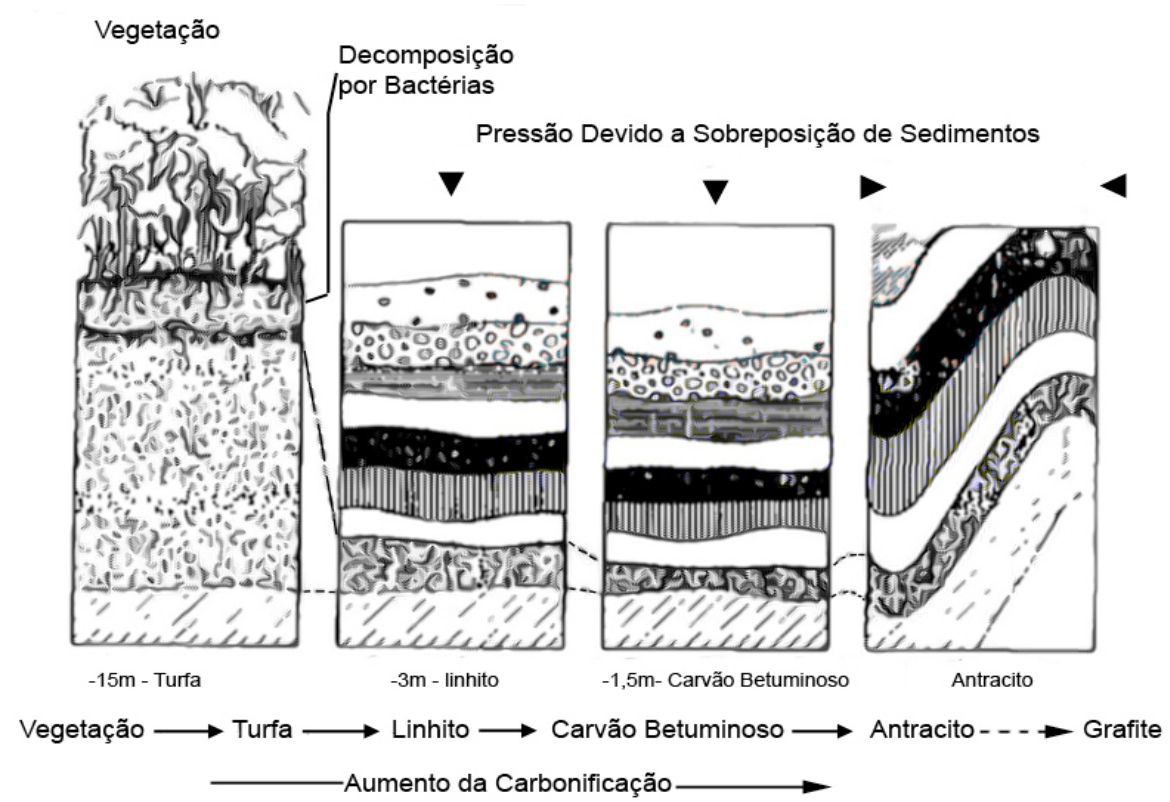

Figura 2.2.3 - Processo de carbonificação (HAENEL, 1992).

Artificialmente, pode-se reproduzir, ainda que não perfeitamente, as formas de carbono produzidas pela natureza, todas constituídas de camadas de grafeno (figura 2.2.2 (a)), variando sua forma de menos estruturada devido distorções entre os planos de grafeno a mais estruturada - o grafite, mostrado na figura 2.2.4 (WISSLER, 2006).

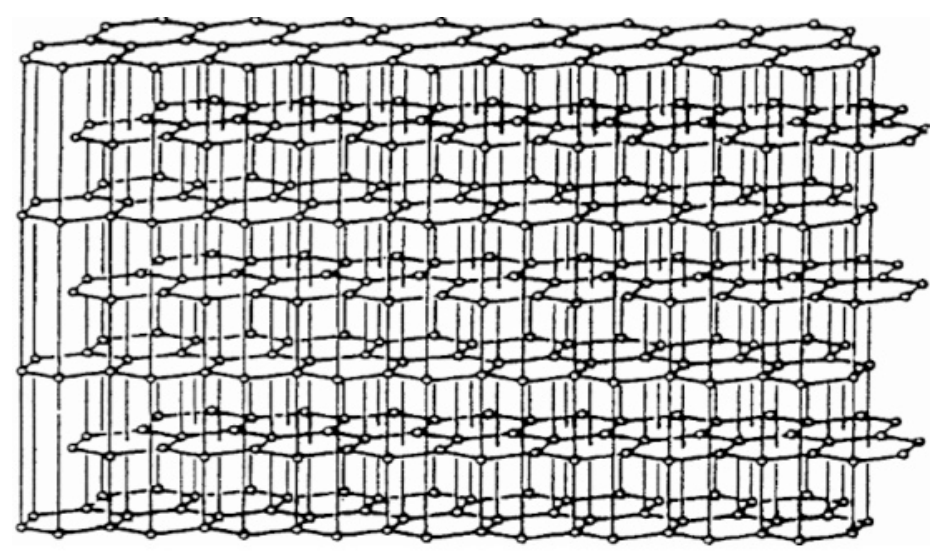

Figura 2.2.4 - Estrutura cristalina do grafite na forma hexagonal e camadas na sequência ABA (WISSLER, 2006). 


\subsubsection{COQUE DE PETRÓLEO}

O coque de petróleo provém da fração mais pesada do processo de destilação do petróleo crú que, também dependendo da sua pureza e condições de processamento (verde ou calcinado), podem ser produzidos diferentes tipos, que qualificando microscopicamente, temos quanto a sua morfologia: o coque em agulhas que consiste em camadas de grafeno altamente estruturadas; coque comum com irregularidades na orientação das camadas de grafeno e por último o coque esponja que apresenta elevada quantidade de poros na sua estrutura (WISSLER, 2006).

\subsubsection{NEGRO DE FUMO}

O negro de fumo pode ser obtido por diversos processos que têm em comum a matéria-prima, ou seja, combustíveis líquidos ou gasosos que, após queima em atmosfera pobre de oxigênio deixa como resíduo, o negro de fumo. Atualmente o melhor processo de produção de negro de fumo é aquele em que, após sua combustão incipiente, é imediatamente resfriado em água, implicando em tamanhos de partículas que variam de $5 \mathrm{~nm}$ a $100 \mathrm{~nm}$, bem como na forma e o grau de agregação dessas partículas que podem ser esféricos, elípticos, lineares e ramificados (WISSLER, 2006).

A figura 2.2.2.1 extraída de Wissler (2006), apresenta uma partícula esférica de negro de fumo, mostrando as camadas concêntricas de grafite que vão perdendo seu ordenamento à medida que se aproxima do centro.

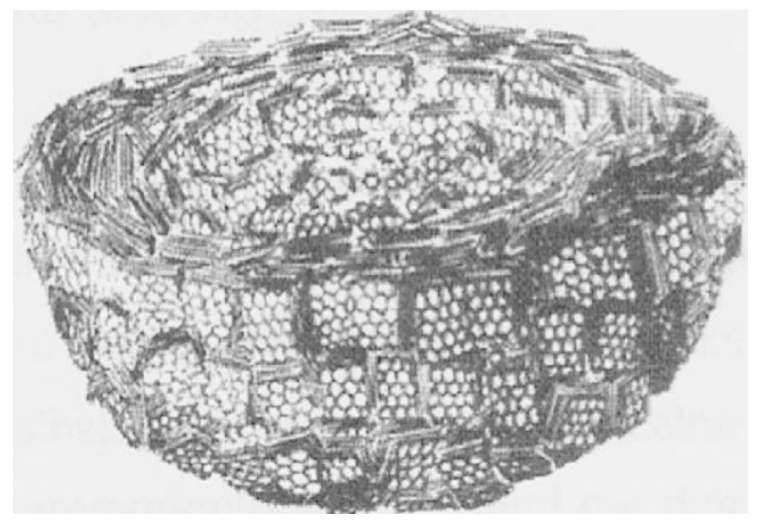

Figura 2.2.2.1 - Modelo mostrando a secção de uma partícula esférica de negro de fumo, onde podemos observar a orientação paralela do grafite nas extremidades e perdendo-a em direção ao centro (WISSLER, 2006). 


\subsubsection{GRAFITE}

O grafite pode ser sintético ou natural. Sua principal característica é que cada partícula é composta de numerosos cristais que podem ser descritos como camadas paralelas constituídas de anéis hexagonais como mostrado na figura 2.2.4, segundo a sequência de empilhamento $A B A B$.

O grafite natural ocorre sob as formas de floco e veios, na primeira forma aparece em grandes cristais orientados na forma de lamelas como podemos observar na figura 2.2.3.1 e na segunda de forma condensada apresentando-se como lascas (WISSLER, 2006).

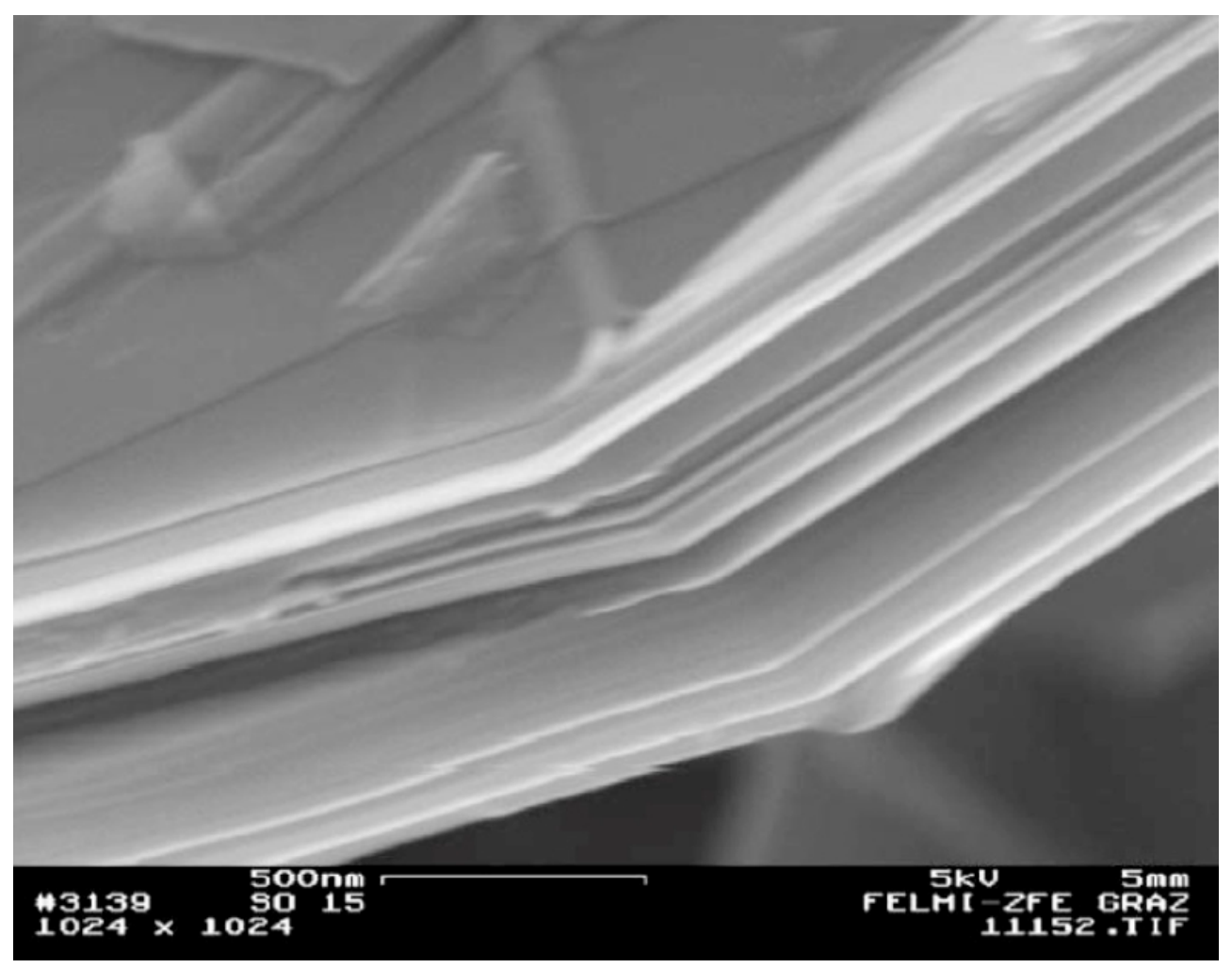

Figura 2.2.3.1. - Imagem de elétrons secundários da estrutura lamelar de um grafite em floco a partir de um microscópio eletrônico de varredura (WISSLER, 2006).

O grafite sintético é produzido em forno elétrico da mesma forma que o carboneto de silício - processo Acheson - onde basicamente o carbono não estruturado é aquecido até a temperatura da ordem de $2.500^{\circ} \mathrm{C}$ para que este possa orientar suas camadas na forma do grafite (WISSLER, 2006). 


\subsubsection{CARVÃO VEGETAL}

Naturalmente, o carvão vegetal se forma à medida que o solo orgânico vai se decompondo e indo para a camada inferior, somada a pressão dos solos que se depositam acima e aumento da temperatura com aumento da profundidade.

O carvão vegetal produzido não naturalmente, corresponde ao carbono restante da queima de toda a matéria orgânica que compõem a madeira, ou melhor, a matéria vegetal em atmosfera pobre de oxigênio restando apenas o carbono, processo esse definido como pirólise.

A tabela 2.2.4.1 a seguir, extraído de Brito (1990), apresenta os produtos gerados durante a produção do carvão vegetal.

Tabela 2.2.4.1 - Descrição qualitativa das fases que se apresentam durante a formação do carvão vegetal por pirólise extraído de (BRITO, 1990).

\begin{tabular}{|c|c|c|}
\hline FASE & TEMPERATURA $\left({ }^{\circ} \mathrm{C}\right)$ & FENOMENOS E PRODUTOS \\
\hline I & Até 200 & $\begin{array}{l}\text { - } \text { Poucas reações importantes } \\
\text { - } \quad \text { Perda de umidade } \\
\text { - } \text { Fase endotérmica }\end{array}$ \\
\hline II & 200 até $270-280$ & $\begin{array}{l}\text { - Aumento de reação e na eliminação de gases } \\
\text { - A madeira passa para a cor marrom arroxeada } \\
\text { - Fase endotérmica }\end{array}$ \\
\hline III & 280 até $350-380$ & $\begin{array}{l}\text { - Importante fase de reações e grande eliminação de gases } \\
\text { - Composição dos gases: centenas de componentes quimicos orgânicos (alguns } \\
\text { recuperáveis) } \\
\text { Ex: Ácido Acético, Metanol, , Acetona, Fenóis, Aldeídos, Hidrocarbonetos, Alcatrões, etc. } \\
\text { - O resíduo final dessa fase já é o carvão vegetal, mas que ainda apresenta compostos } \\
\text { volatilizáveis em sua estrutura. } \\
\text { - Fase exotérmica. }\end{array}$ \\
\hline IV & $380-500$ & $\begin{array}{l}\text { - } \quad \text { Redução da saída de gases } \\
\text { - O carvão vegetal passa a sofrer uma purificação na sua composição química com a } \\
\text { eliminação do restante dos gases voláteis contendo H e O. O carvão torna-se mais rico } \\
\text { em carbono em sua estrutura (carvão não volatilizável ou carbono fixo) } \\
\text { - Fase exotérmica. }\end{array}$ \\
\hline V & Acima de 500 & $\begin{array}{l}\text { - Degradação do carvão } \\
\text { - Término da carbonização e início da gaseificação do carvão } \\
\text { - Fase exotérmica. }\end{array}$ \\
\hline
\end{tabular}




\subsubsection{TURFA}

A turfa, objeto de verificação deste estudo, é definida como sendo uma substância fóssil, orgânica e mineral, originada de decomposição de restos vegetais, encontrada nas áreas alagadiças como várzeas de rios, planícies costeiras e regiões lacustres (FRANCHI et al., 2003).

Trata-se de um biólito, isto é, um depósito sedimentar desenvolvido a partir de processos biológicos de decomposição. Sendo passível de utilização como combustível, posiciona-se na categoria de caustobiólitos (grego kausticós = que queima). A conversão da matéria vegetal em turfa é um processo cuja continuação por alterações diagenéticas ou metamórficas, conduz à formação de linhito, carvão e antracito (FRANCHI et al., 2003).

A figura 2.2.5.1 mostra de forma geral, como a turfa se apresenta na natureza.

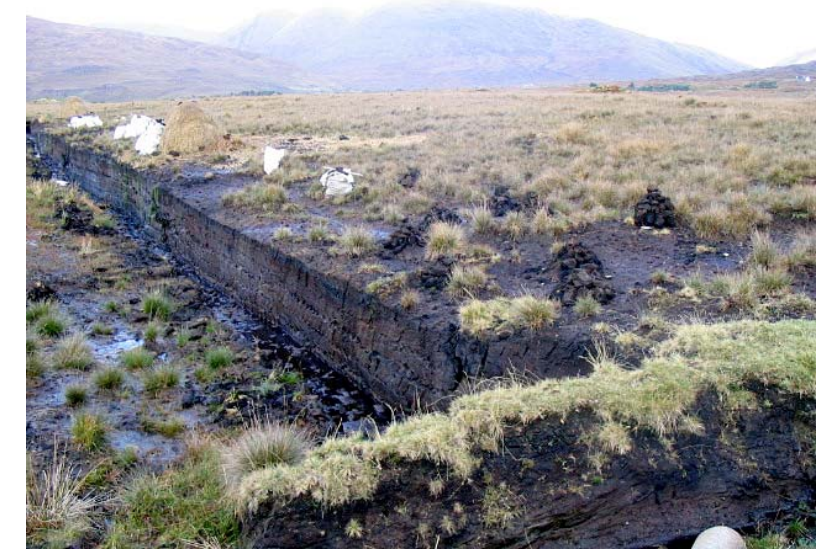

Figura 2.2.5.1 - Exemplo de turfa em seu estado natural [fonte: www.commons.wikimedia.org/wiki/File:Peat-bog-Ireland.jpg]

Segundo Silva et al. (1987), suas propriedades variam muito com a natureza do material de origem, com o grau de decomposição e com a quantidade de fibras. É ratificado ainda que, quanto maior o grau de decomposição são maiores também a densidade, teor de carbono fixo e poder calorífico.

O que é interessante depreender, é que, uma vez em fase inicial de decomposição das cadeias orgânicas constituintes da matéria vegetal, ocorre grande quantidade de elementos que durante o processo de redução carbotérmica volatizam, podendo participar da reação de redução, que deixam uma intricada rede de canais dentro da massa de carbono disponível para a formação do carboneto de 
silício da mesma forma como pode ocorrer para o carvão vegetal, com a diferença de que os voláteis formados não participam do processo de redução.

Por fim, como exposto acima, as turfas (fonte de carbono) são oriundas de um processo sedimentar, bem como muitos dos depósitos de areias quartzosas (fontes de sílica) como é mostrado na figura 2.2.5.2, onde fica evidenciado o processo de deposição caracterizado pela estratigrafia apresentada por essa jazida de areia de quartzo de explotação dedicada á indústria vidreira.

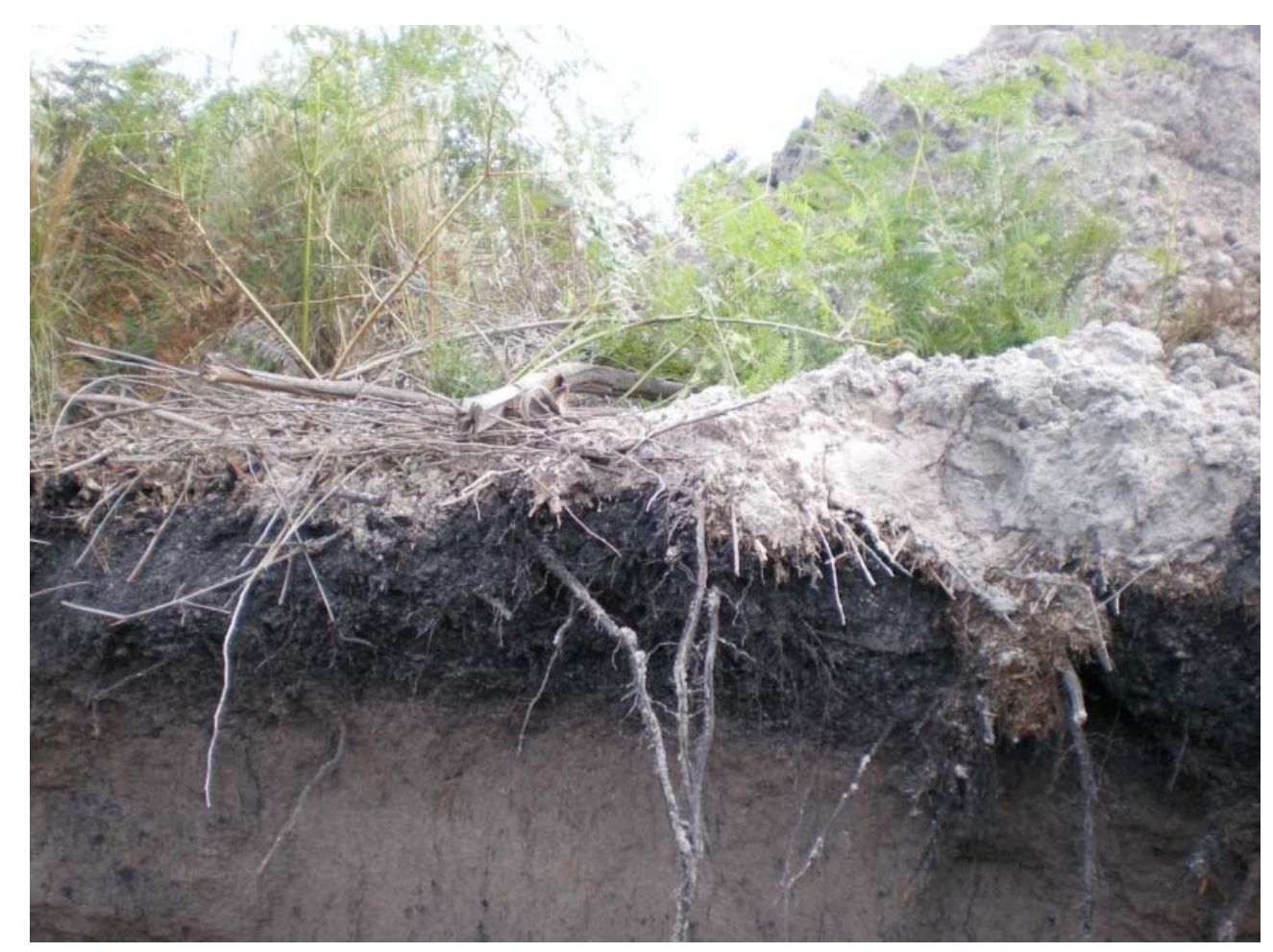

Figura 2.2.5.2 - Frente de lavra com destaque a estratigrafia dos sedimentos de turfa, variando de $30 \mathrm{~cm}$ a $1 \mathrm{~m}$ e logo abaixo, areia de sílica

Pode-se então, estudar o potencial de redução da turfa na obtenção do carboneto de silício, que se comprovado possível, viabilizará maior aproveitamento econômico de jazidas de areias de quartzo que apresentam as mesmas características, uma vez que, teríamos a fonte de sílica e redutor (turfa) na mesma mina ou jazida. 
3. OBJETIVO.

O objetivo do presente trabalho foi comparar a redução carbotérmica de quartzo moído, utilizando a turfa (TF) como redutor, com os redutores carbonosos convencionais como: coque de petróleo (CQ), carvão vegetal (CV), grafite (GF) e negro de fumo (NF), visando a produção de carboneto de silício. 


\section{PROCEDIMENTOS EXPERIMENTAIS}

Como o objetivo é obter o carboneto de silício variando as fontes de carbono, foi mantida constante a fonte de sílica proveniente de quartzo moído, cujas

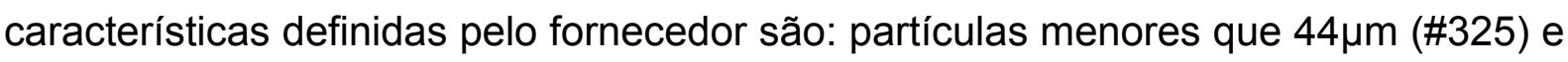
teor de sílica de $99,8 \%$. Houve confirmação do tamanho médio dessas partículas, descrito no próximo item, pela técnica de difração a Laser, morfologia observada por microscopia eletrônica de varredura (MEV) e verificação da pureza de algumas delas por espectroscopia de energia dispersiva de raios $\mathrm{X}$ (EDS).

As fontes de carbono ou redutores como o coque de petróleo (CQ), carvão vegetal (CV) e grafite (GF) sofreram cominuição e seleção de partículas, sendo separadas para o experimento apenas aquelas menores que $44 \mu \mathrm{m}$ (\#325), a fim de garantir a área de contato entre os reagentes $O$ negro de fumo assim como a sílica foram utilizados na sua forma original quanto a composição química e tamanho de partículas. Todas as fontes de carbono foram analisadas quanto aos teores de carbono fixo, umidade, matéria volátil e cinzas.

Em seguida, as etapas de homogeneizar, secar, homogeneizar novamente os reagentes, são necessárias para aumentar suas áreas de contado.

As amostras foram encaminhadas ao forno de atmosfera de argônio e aquecidas nas temperaturas de $1550^{\circ} \mathrm{C}, 1600^{\circ} \mathrm{C}$ e $1650^{\circ} \mathrm{C}$ por quatro horas e resfriadas até temperatura ambiente. Em seguida foram caracterizadas por microscopia eletrônica de varredura (MEV), espectroscopia de energia dispersiva de raios $X$ e análise de difração de raios $X$, a fim de verificar a morfologia, identificar elementos e fases presentes nos produtos da reação de redução para cada uma das temperaturas especificadas anteriormente, além de novo ensaio de perda ao fogo e nova análise das fases presentes por difração de raios $X$ para os produtos provenientes do redutor negro de fumo (NF) para confirmação de algumas fases, como melhor descrito no item 5 .

A figura 4.1 representa esquematicamente o fluxograma em blocos dos procedimentos realizados. 


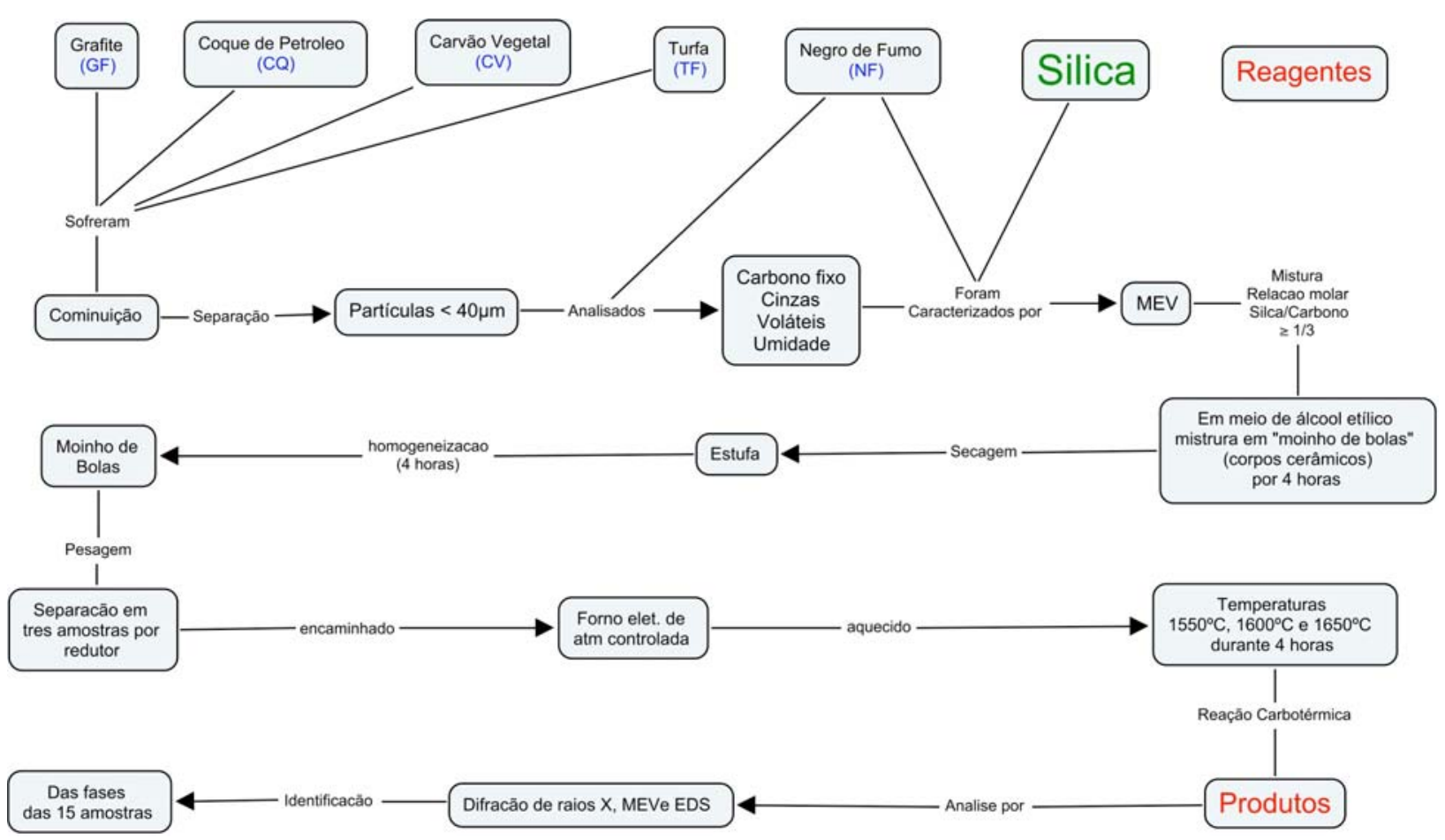

Figura 4.1 - Esquema em blocos dos procedimentos realizados.

\subsection{MATERIAIS USADOS COMO REAGENTES}

\section{- SÍLICA}

A sílica utilizada é proveniente da moagem de lascas de quartzo, obtida da empresa MINASOLO, de pureza igual a $99,80 \%$ de $\mathrm{SiO}_{2}(\mathrm{~s})$, sendo que os elementos restantes não foram especificados. Apresenta-se na forma de pó de cor branca, com retenção na \#325 menor que 4,0\%, cuja distribuição granulométrica, obtida por granulômetro a laser (CILAS) apresentou tamanho médio de partículas igual a $36,43 \mu \mathrm{m}$, e superfície lisa conforme se depreende da figura 4.1.1, tabela 4.1.1. e figura 4.1 .3 respectivamente. 


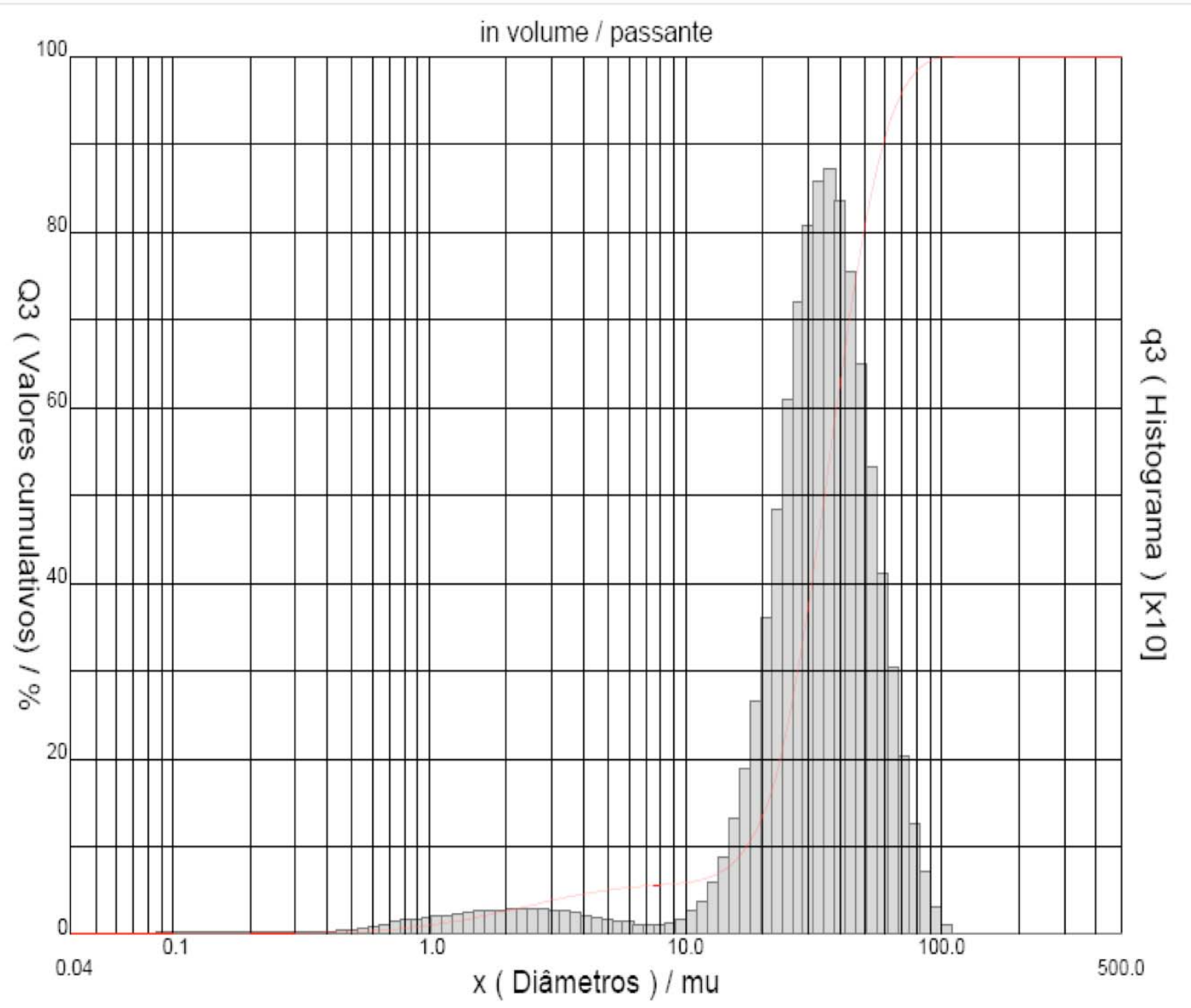

Figura 4.1.1 - Distribuição dos tamanhos das partículas de sílica por granulômetro a Laser.

Tabela 4.1.1 - Valores da distribuição dos tamanhos das partículas e seu diâmetro médio.

\begin{tabular}{cc}
\hline Diâmetro a (\%) & $(\mu \mathrm{m})$ \\
\hline \hline $10 \%$ & 17.32 \\
$50 \%$ & 34.80 \\
$90 \%$ & 58.99 \\
\hline
\end{tabular}

Diâmetro Médio $=36.43 \mu \mathrm{m}$ 
Com o objetivo de confirmar os dados de composição química apresentados pelo fornecedor, foi feito, durante a caracterização da morfologia e da superfície dos grãos de sílica moída por meio de microscopia eletrônica de varredura (MEV) Philips Modelo XL 30 - análise dos elementos químicos de determinada partícula de forma cúbica, que apresentava clivagem, conforme se observa na figura 4.1.1, utilizando-se de espectroscopia de dispersão de raios X (EDS) - EDAX XL 30 a qual poderia ser de composição química diferente a da sílica, pois esta, não possui plano de clivagem. O que não se confirmou, pois o resultado apresentado na figura 4.1.2 identifica o Si e O como constituintes da partícula em questão. Pode-se então considerar a composição química coerente com o afirmado pelo fornecedor.

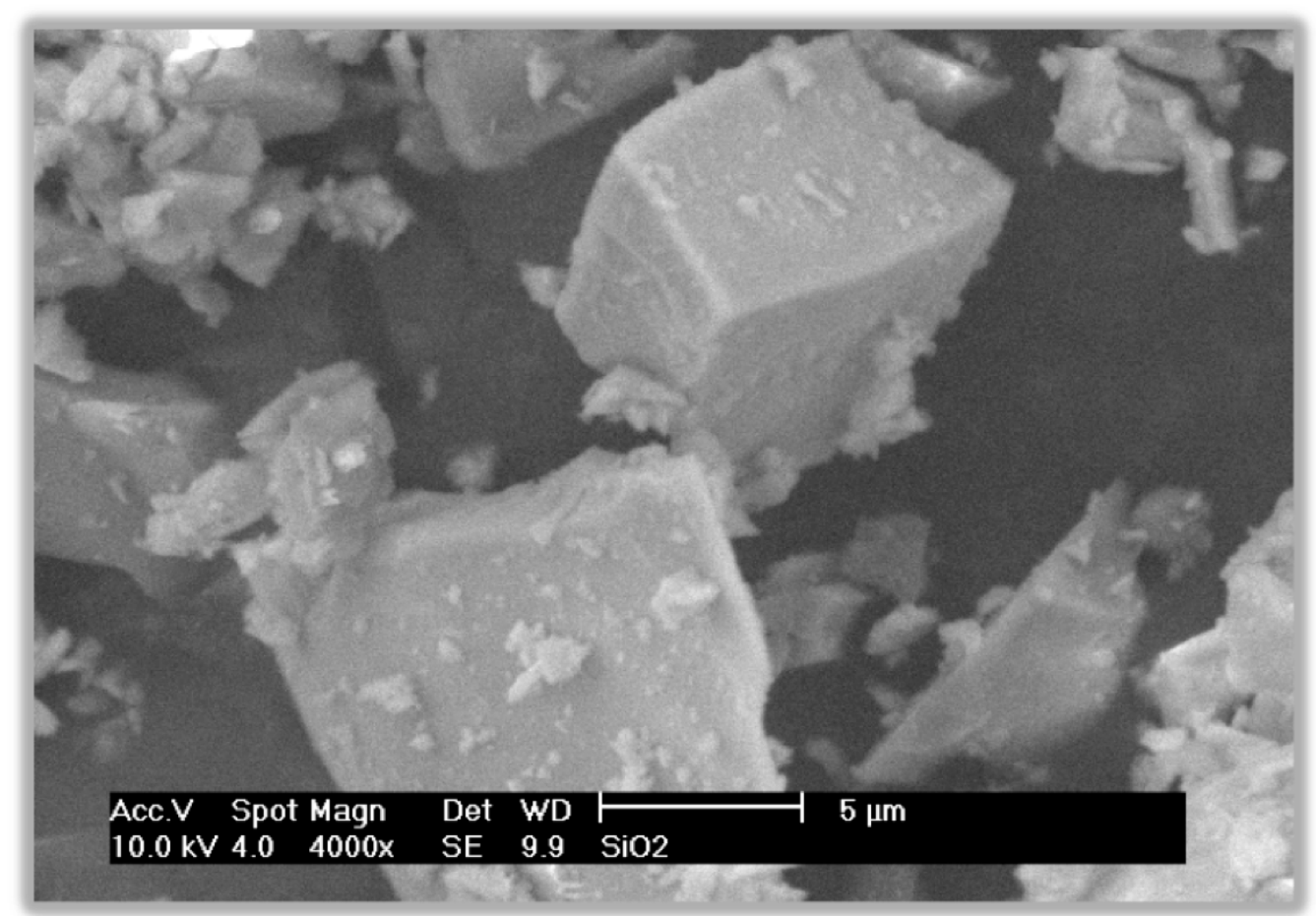

Figura 4.1.1 - Imagem de elétrons secundários das partículas com clivagem. 


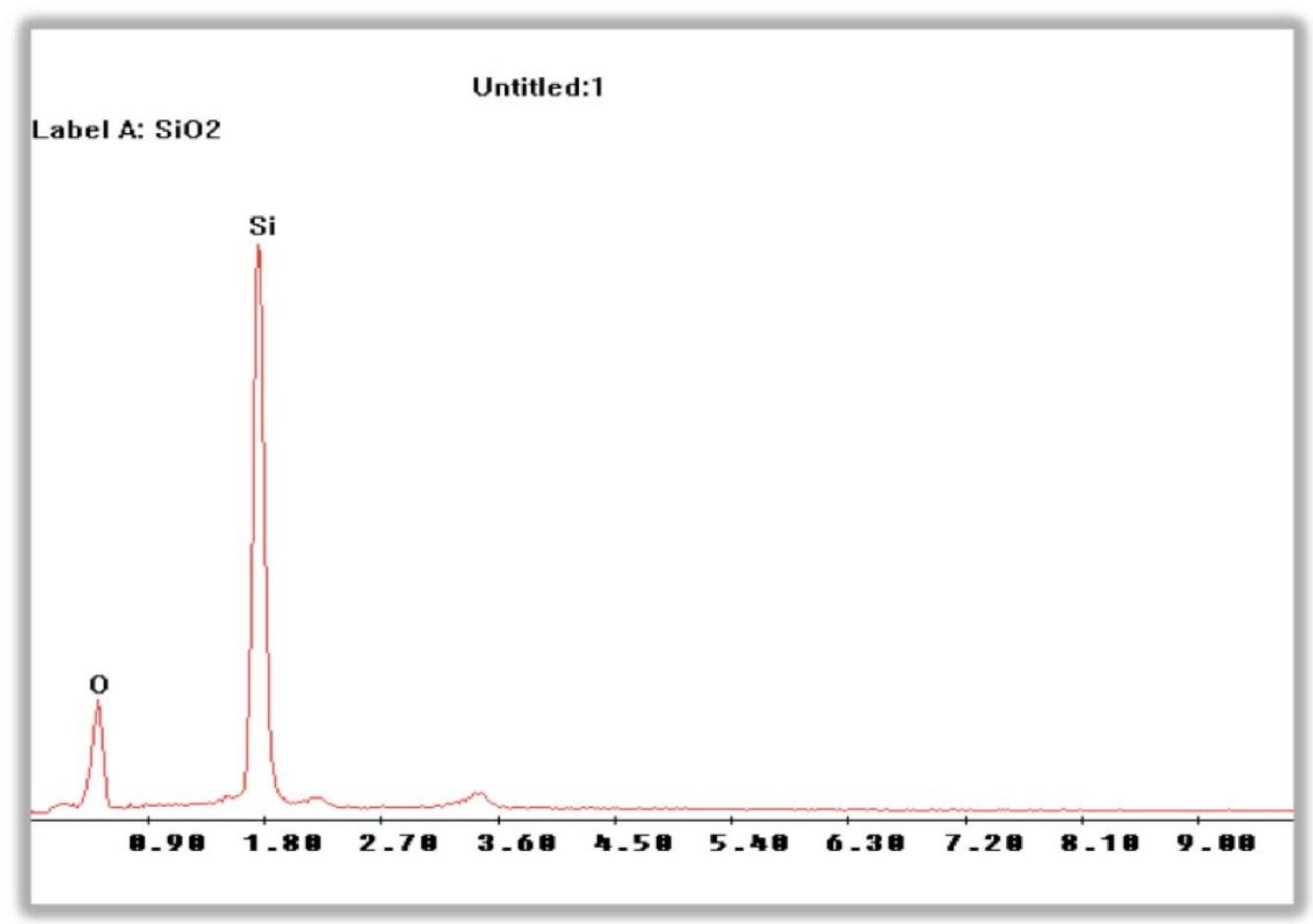

Figura 4.1.2 - Elementos presentes nas partículas com clivagem da foto 4.1.1 obtidos por EDS.

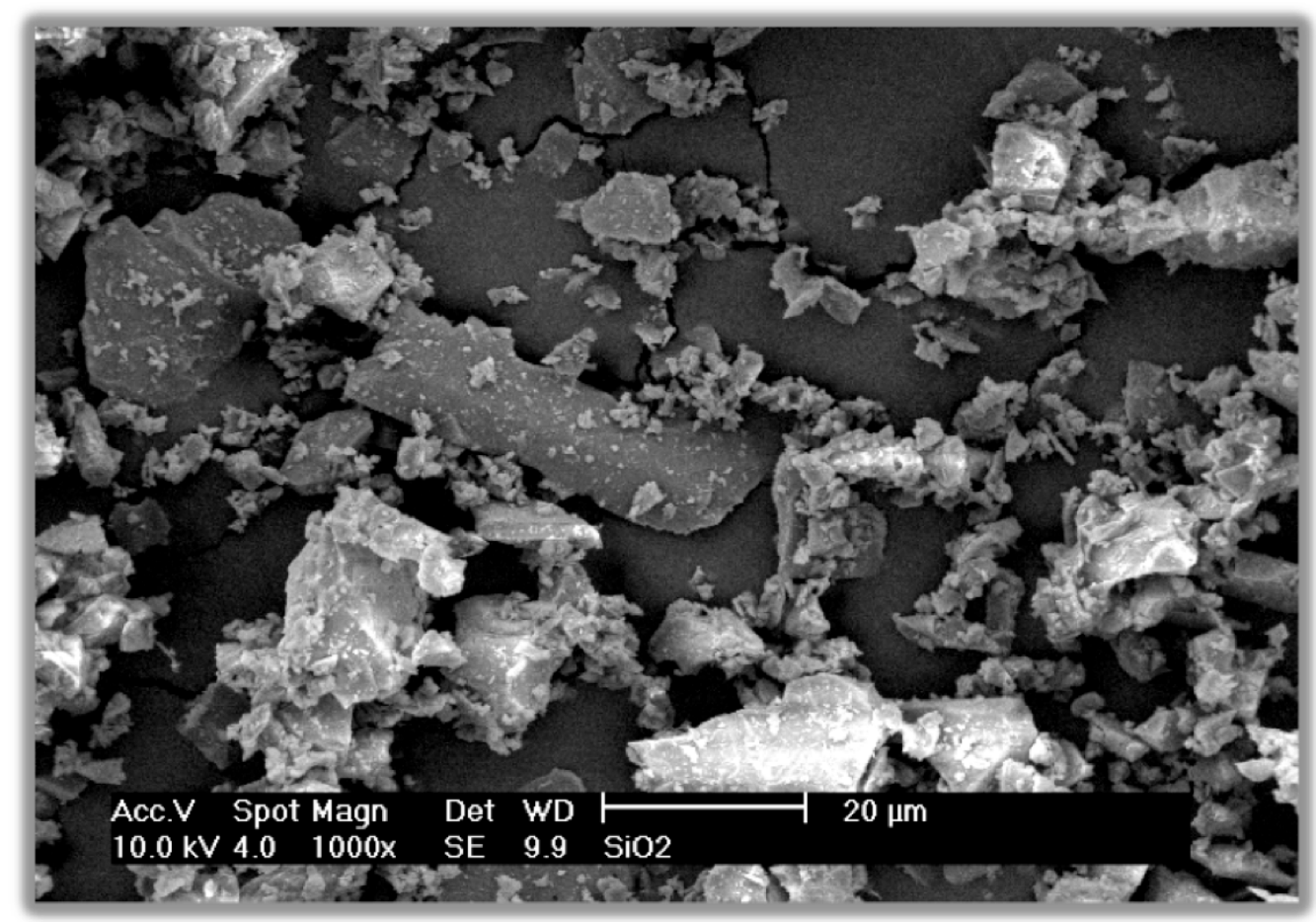

Figura 4.1.3 - Imagem de elétrons secundários das partículas de sílica que apresentam superfície lisa. 


\section{- NEGRO DE FUMO}

O negro de fumo, adquirido da indústria CABOT garante pureza ou teor de carbono acima de $98,0 \%$. Os valores de carbono fixo, voláteis, cinzas e umidade estão descritos na tabela 4.1.2.

Nas figuras 4.1 .4 e 4.1 .5 obtidas por microscopia eletrônica de varredura (MEV) é possível observar a homogeneidade dos tamanhos das partículas, bem como, um tamanho médio de 100nm.

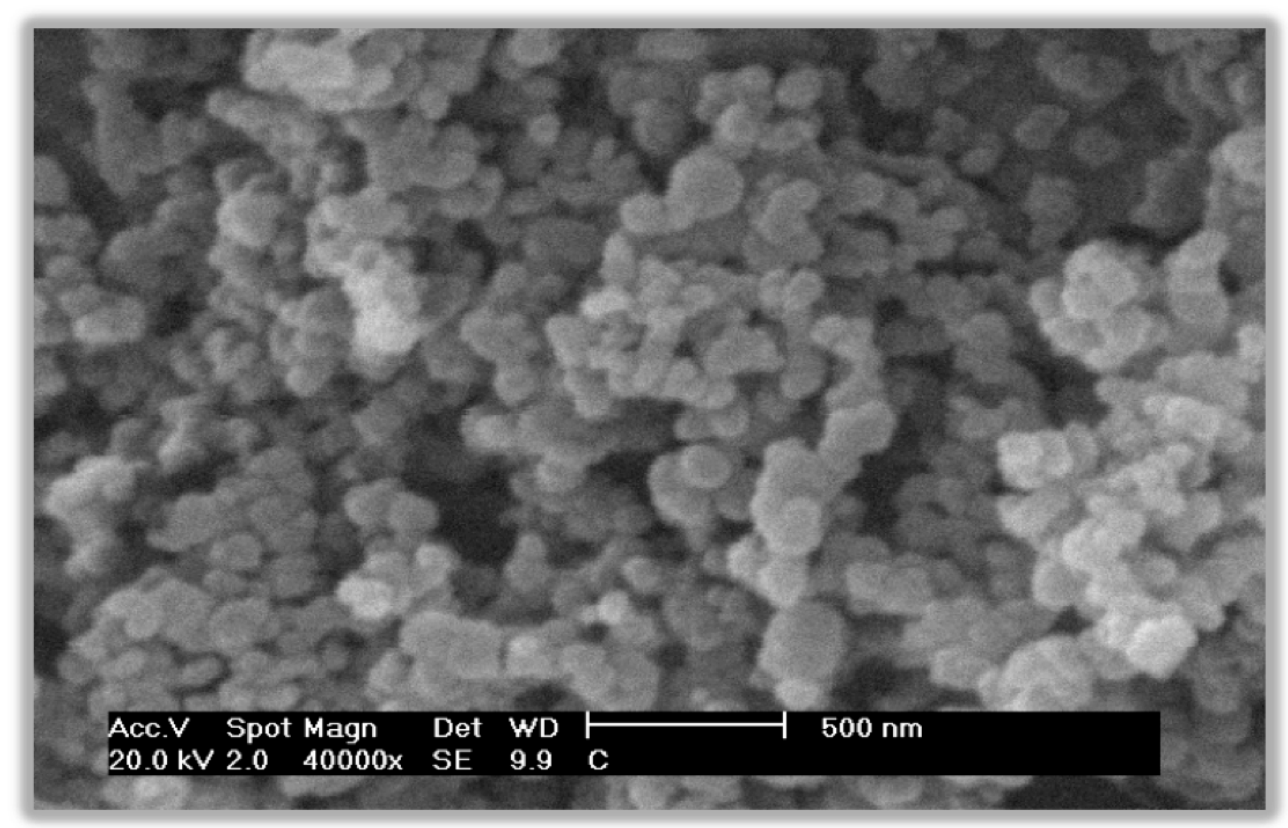

Figura 4.1.4 - Imagem de elétrons secundários das partículas do negro de fumo.

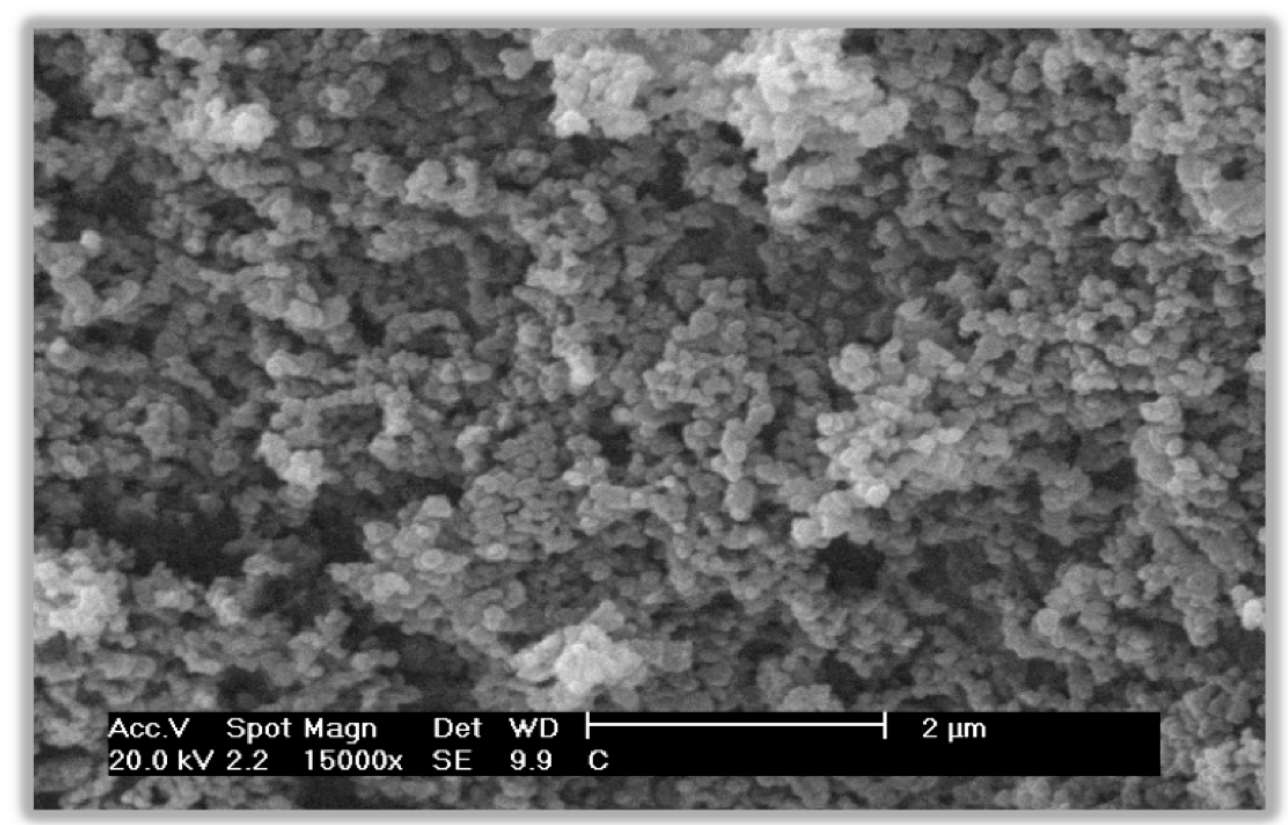

Figura 4.1.5 - Imagem de elétrons secundários das partículas do negro de fumo. 
- TURFA

A turfa obtida na região do Município de Criciúma no estado de Santa Catarina, cujos valores de carbono fixo, voláteis, cinzas e umidade estão descritos na tabela 4.1.2, foi seca e moída e selecionada para o ensaio as amostras com partículas menores que $44 \mu \mathrm{m}$ (\#325).

A figura 4.1.6 obtida por microscopia eletrônica de varredura (MEV) mostra a forma e a distribuição das partículas no campo de observação.

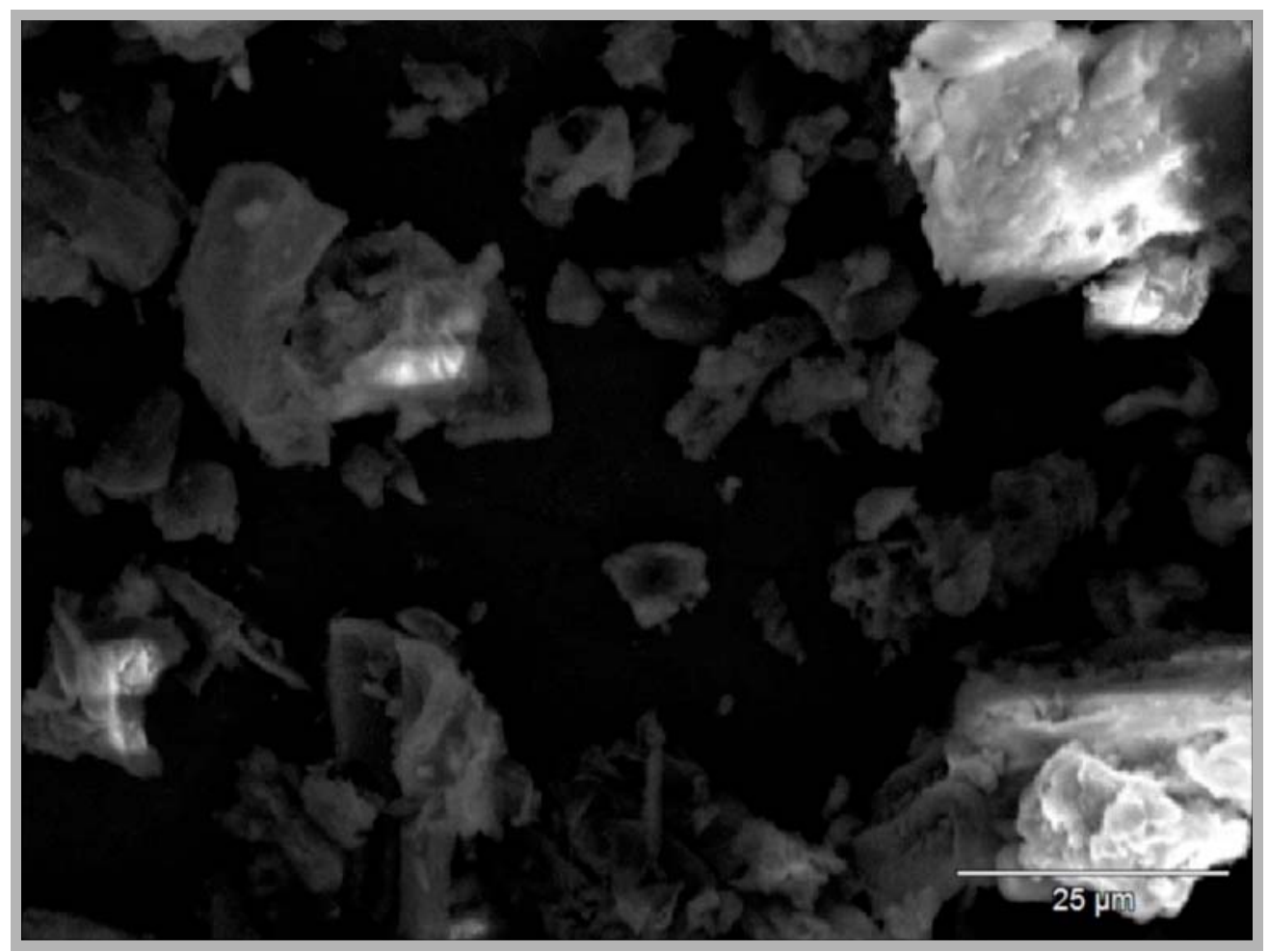

Figura 4.1.6 - Imagem de elétrons secundários das partículas de turfa. As áreas claras são resultado da ionização dos voláteis presentes nas partículas. 


\section{- CARVÃo VEGETAL}

O carvão vegetal foi seco, moído, peneirado e separada a fração das partículas menores que $44 \mu \mathrm{m}$ (\#325) destinadas ao procedimento experimental e os valores de carbono fixo, voláteis, cinzas e umidade estão descritos na tabela 4.1.2

A figura 4.1.7 obtida por microscopia eletrônica de varredura (MEV) apresenta o aspecto morfológico do campo observado.

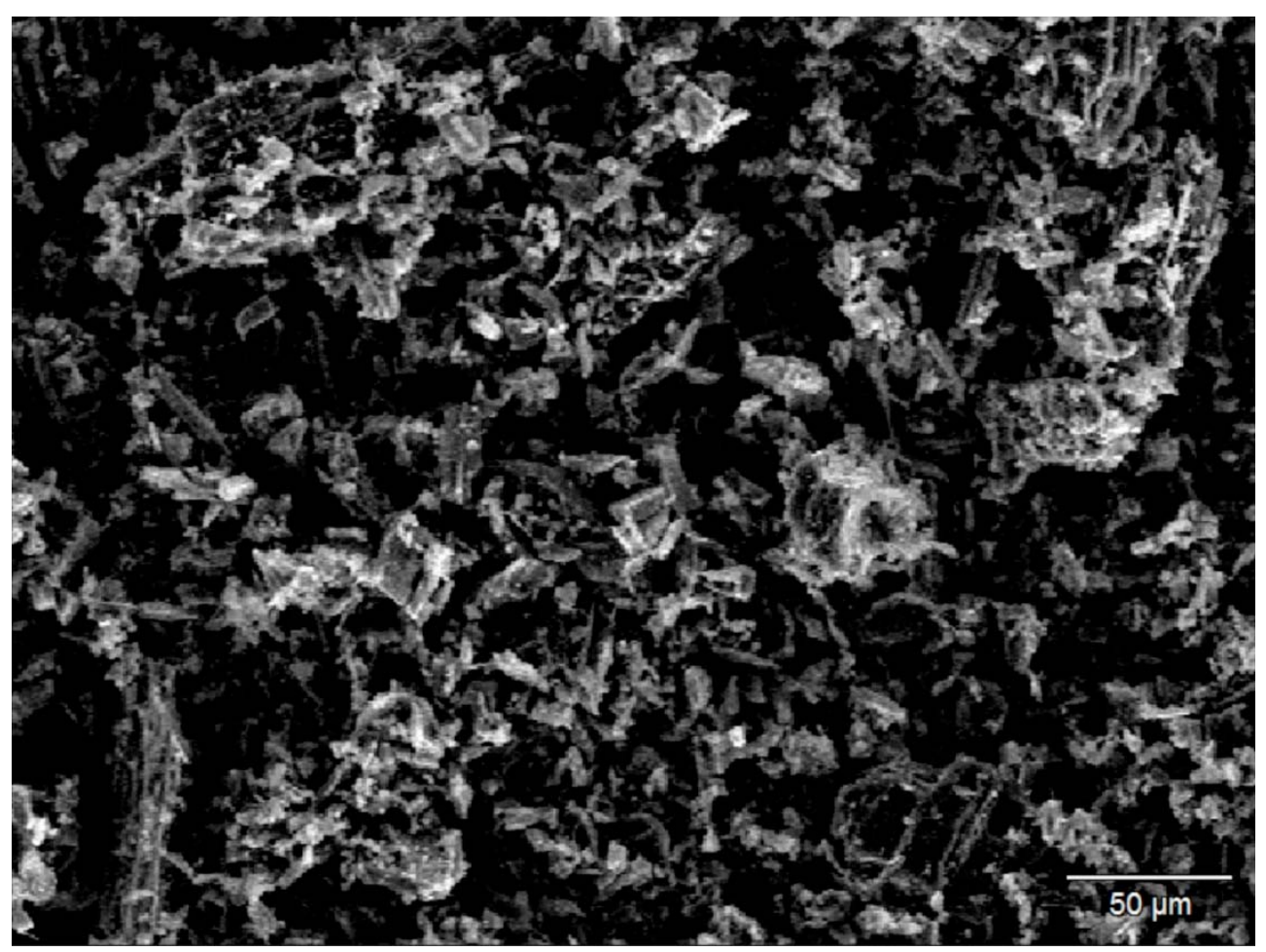

Figura 4.1.7 - Imagem de elétrons secundários das partículas do carvão vegetal. 


\section{- COQUE DE PETRÓLEO}

O coque de petróleo foi seco, moído, peneirado e separadas a fração das partículas menores que $44 \mu \mathrm{m}$ (\#325) destinadas ao procedimento experimental e feito a análise de carbono fixo, voláteis, cinzas e umidade cujos valores estão descritos na tabela 4.1 .2

A figura 4.1.8 obtida por microscopia eletrônica de varredura (MEV) apresenta o aspecto morfológico do campo observado.

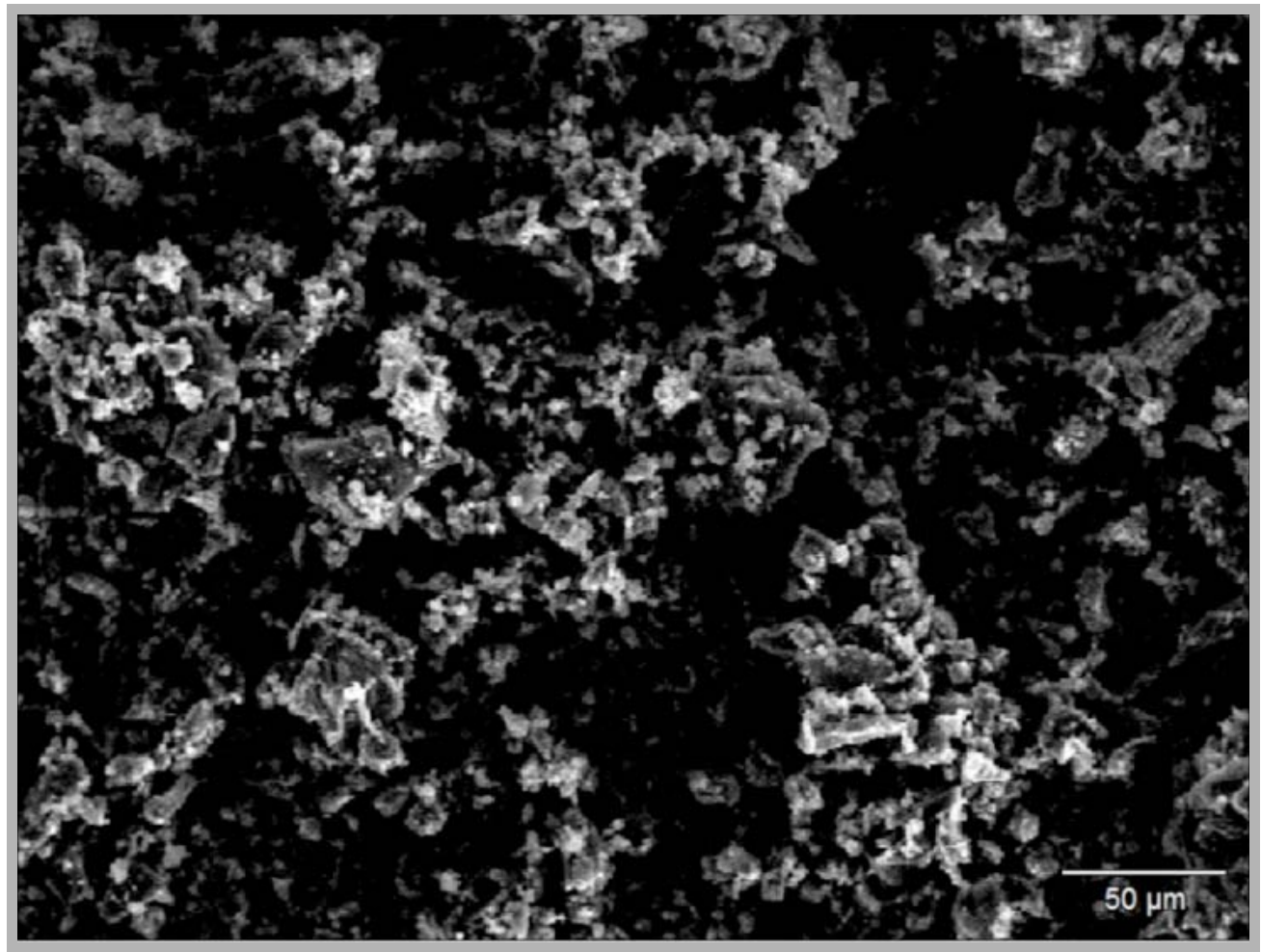

Figura 4.1.8 - Imagem de elétrons secundários das partículas do coque de petróleo 


\section{- GRAFITE}

O grafite foi seco e peneirado separando a fração das partículas menores que $44 \mu \mathrm{m}(\# 325)$ destinadas ao procedimento experimental.

A figura 4.1.9 obtida por microscopia eletrônica de varredura (MEV) apresenta o aspecto morfológico do campo observado, demonstrando que trata-se de grafite natural pelo aspecto lamelar apresentado por suas partículas.

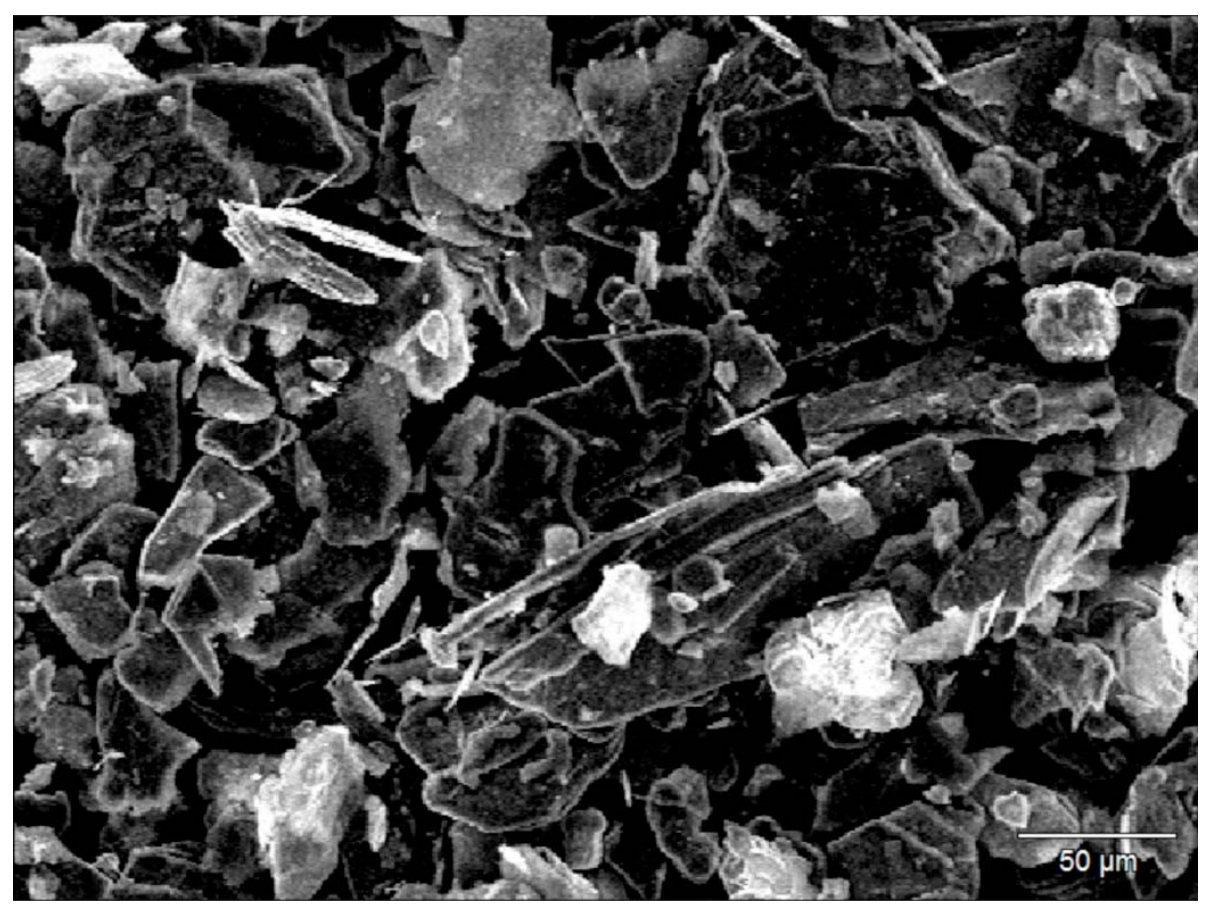

Figura 4.1.9 - Imagem de elétrons secundários das partículas de grafite de caráter lamelar.

Para todas as fontes de carbono, como já mencionado, foram realizados os ensaios de carbono fixo, voláteis, cinzas e umidades, conforme ABNT (1983), a fim de, conhecendo estes teores, compor a relação molar que garanta que não haja falta de carbono disponível para a reação de redução. A tabela 4.1.2 apresenta os referidos valores, respectivamente para as cinco amostras, ou seja, turfa (TF), carvão vegetal (CV), coque de petróleo (CQ), grafite (GF) e negro de fumo (NF).

Tabela 4.1.2 - Teores de Carbono Fixo, Voláteis, Cinzas e Umidade.

\begin{tabular}{cccccc}
\hline & GF & TF & CV & NF & CQ \\
\hline \hline Carbono Fixo & $92.41 \%$ & $41.02 \%$ & $70.69 \%$ & $98.50 \%$ & $92.15 \%$ \\
Voláteis & $0.62 \%$ & $38.05 \%$ & $22.08 \%$ & $1.16 \%$ & $6.09 \%$ \\
Cinzas & $2.66 \%$ & $16.82 \%$ & $4.06 \%$ & $0.15 \%$ & $1.07 \%$ \\
Umidade & $4.30 \%$ & $4.11 \%$ & $3.17 \%$ & $0.19 \%$ & $0.69 \%$ \\
\hline
\end{tabular}




\subsection{PREPARAÇÃO DOS REAGENTES}

Os reagentes foram secos e misturados na proporção molar de 1 / 3 (CATTAMANCHI, 1998), durante 4 horas em um recipiente de plástico contendo $40 \mathrm{ml}$ de álcool etílico PA e 16 corpos semi-esféricos de $10 \mathrm{~mm}$ de diâmetro de alumina, a fim de melhorar o contato entre os reagentes, bem como o de homogeneizar a mistura.

A figura 4.2.1 mostra o recipiente que recebeu os corpos de homogeneização de alumina e o mesmo recipiente contendo os precursores ou reagentes prontos para receber o álcool etílico e iniciar homogeneização com o auxílio do equipamento da figura 4.2.2 com capacidade de proceder à homogeneização de até 5 frascos ao mesmo tempo.

a)

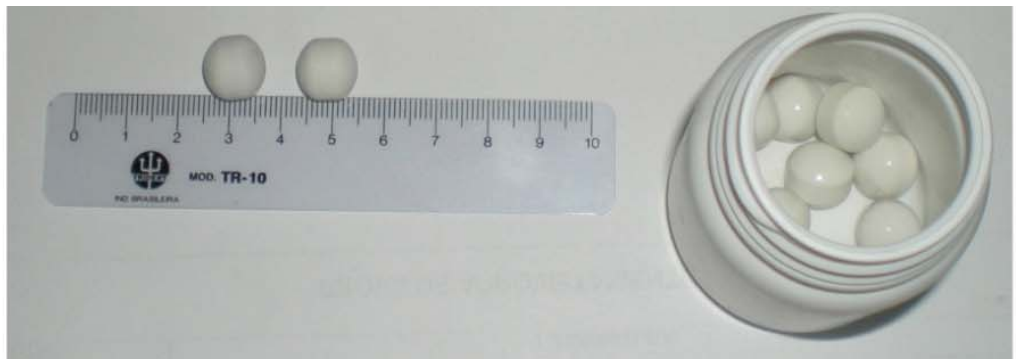

b)

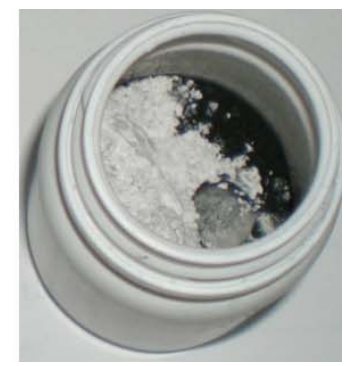

Figura 4.2.1 - Recipiente de plástico contendo os corpos de homogeneização (a) e em (b) já com os reagentes pronto para receber o álcool etílico.

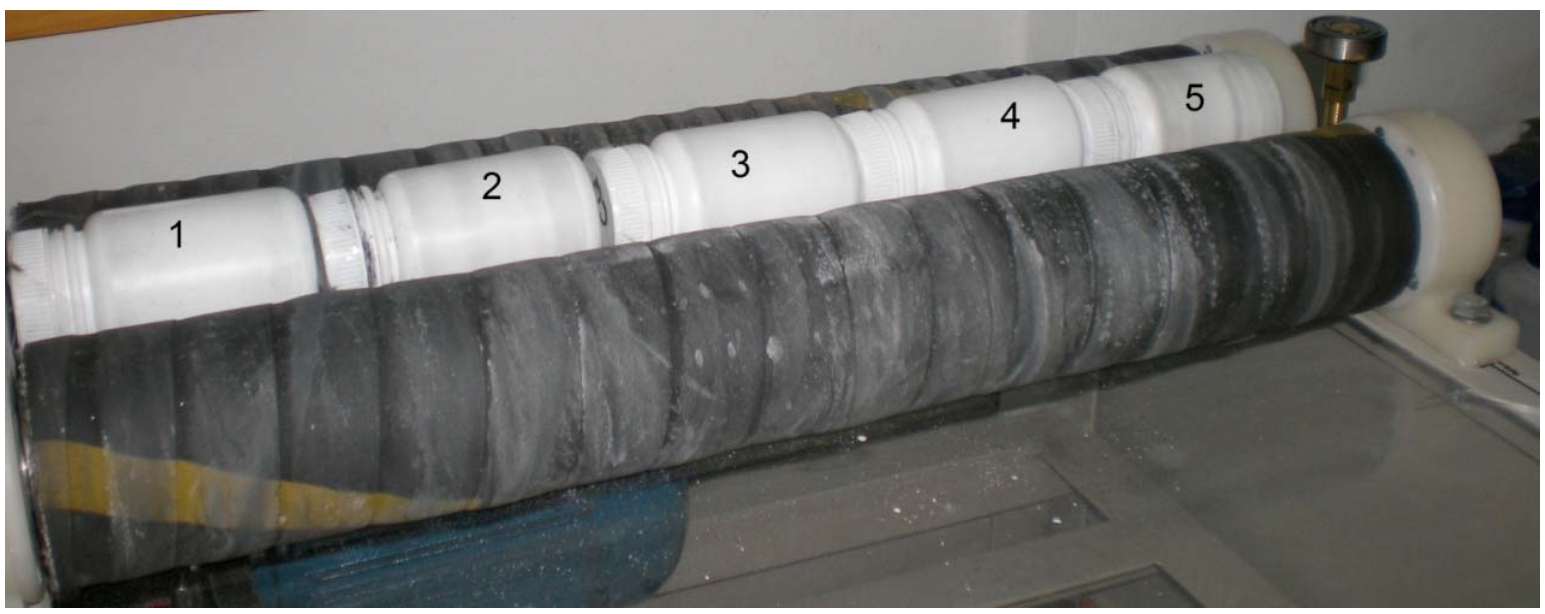

Figura 4.2.2 - Equipamento de homogeneização, operando por rotação com capacidade de 5 frascos de plástico. 
Após a homogeneização as amostras foram transferidas para 5 Beckers, levados a estufa em temperatura de $120^{\circ} \mathrm{C}$ por mais 12 horas, a fim de que todo 0 álcool etílico fosse evaporado. Estando o material seco, este foi levado à nova homogeneização por mais 4 horas, tempo suficiente para eliminar da amostra qualquer eventual segregação que tenha ocorrido durante a secagem do álcool etílico.

\subsection{ENSAIOS DE REDUÇÃO}

As amostras foram colocadas em cadinho de grafite com capacidade total de 4 amostras por cadinho, preenchendo-se cada cavidade aproximadamente até metade de sua altura.

Foram utilizados 2 cadinhos a fim de comportarem as 5 amostras levadas a temperaturas que possam garantir que a reação carbotérmica ocorra, ou seja, acima de $1.515^{\circ} \mathrm{C}$, e, para evitar que fatores cinéticos possam retardar a reação definiramse as temperaturas do ensaio de $1.550^{\circ} \mathrm{C}, 1.600^{\circ} \mathrm{C}$ e $1.650^{\circ} \mathrm{C}$, com 4 horas de permanência em cada uma delas e resfriamento até temperatura ambiente, como condição suficiente para que ocorra a reação de redução.

A figura 4.3.1 apresenta o desenho esquemático do cadinho e a tabela 4.3.1 as massas das misturas iniciais utilizadas no ensaio.
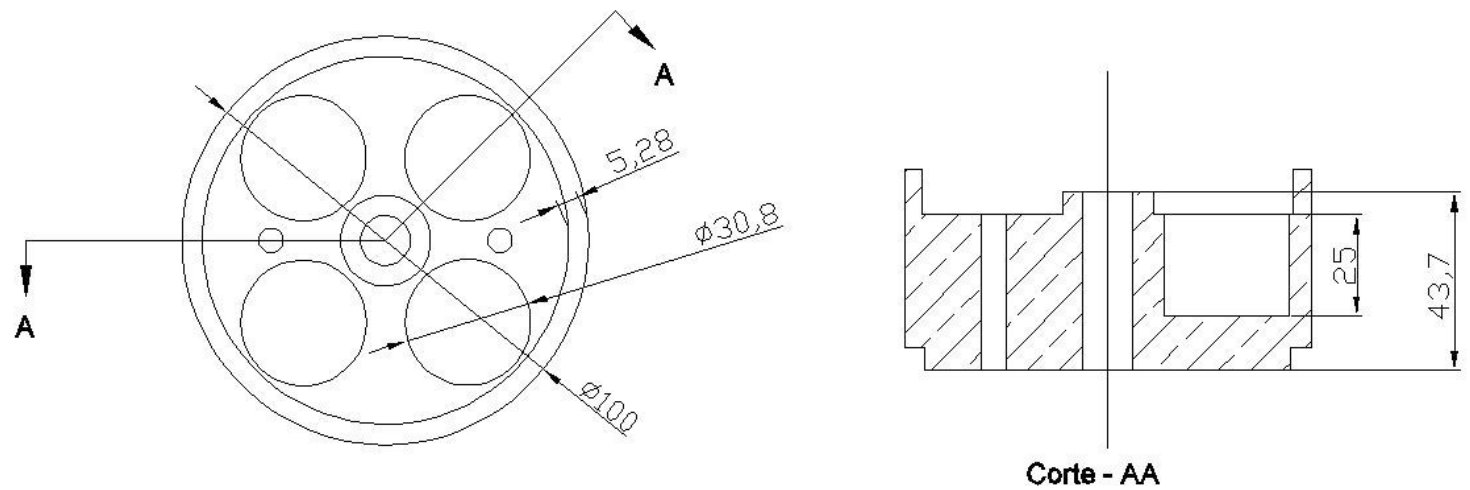

Figura 4.3.1 - Dimensões do cadinho utilizado no ensaio da redução. 
Tabela 4.3.1 - Massa inicial de amostra para cada uma das temperaturas dos ensaios.

Massa Inicial $(\mathrm{g})$ por Ensaio

\begin{tabular}{cccc}
\hline Redutor & $1550^{\circ} \mathrm{C}$ & $1600^{\circ} \mathrm{C}$ & $1650^{\circ} \mathrm{C}$ \\
\hline \hline GF & 2.35 & 2.52 & 2.41 \\
TF & 2.50 & 2.55 & 2.50 \\
CV & 1.20 & 2.50 & 1.14 \\
CQ & 1.49 & 2.51 & 1.66 \\
NF & 1.70 & 2.50 & 1.75 \\
\hline
\end{tabular}

A figura 4.3.2 representa a vista isométrica em corte do forno, destacando os cadinhos em cor verde. Também é mostrado na figura 4.3.3 o forno e seu painel de controle.

Após o acondicionamento no forno do cadinho contendo as amostras iniciouse a operação. Primeiramente fazendo a purga do sistema e em seguida aplicando vácuo passando para atmosfera de argônio (99,999\%) a uma razão de $20 \mathrm{ml} / \mathrm{min}$, até o fim do ensaio, ou seja, aquecimento a uma taxa de aumento de temperatura de $20^{\circ} \mathrm{C} / \mathrm{min}$ (MOTHÉ et al., 2002) até as temperaturas $1.500^{\circ} \mathrm{C}, 1.600^{\circ} \mathrm{C}$ e $1.650^{\circ} \mathrm{C}$ mantendo-se essa temperatura por mais de 4 horas e resfriadas no forno até a temperatura ambiente, como descrito anteriormente.

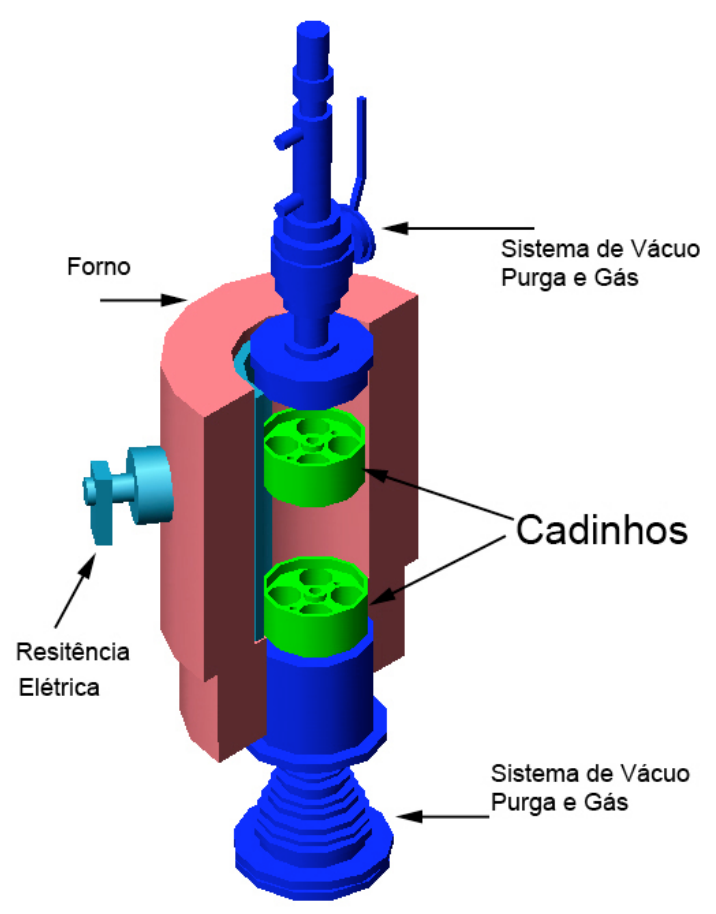

Figura 4.3.2 - Esquema em vista isométrica em corte do forno de redução 


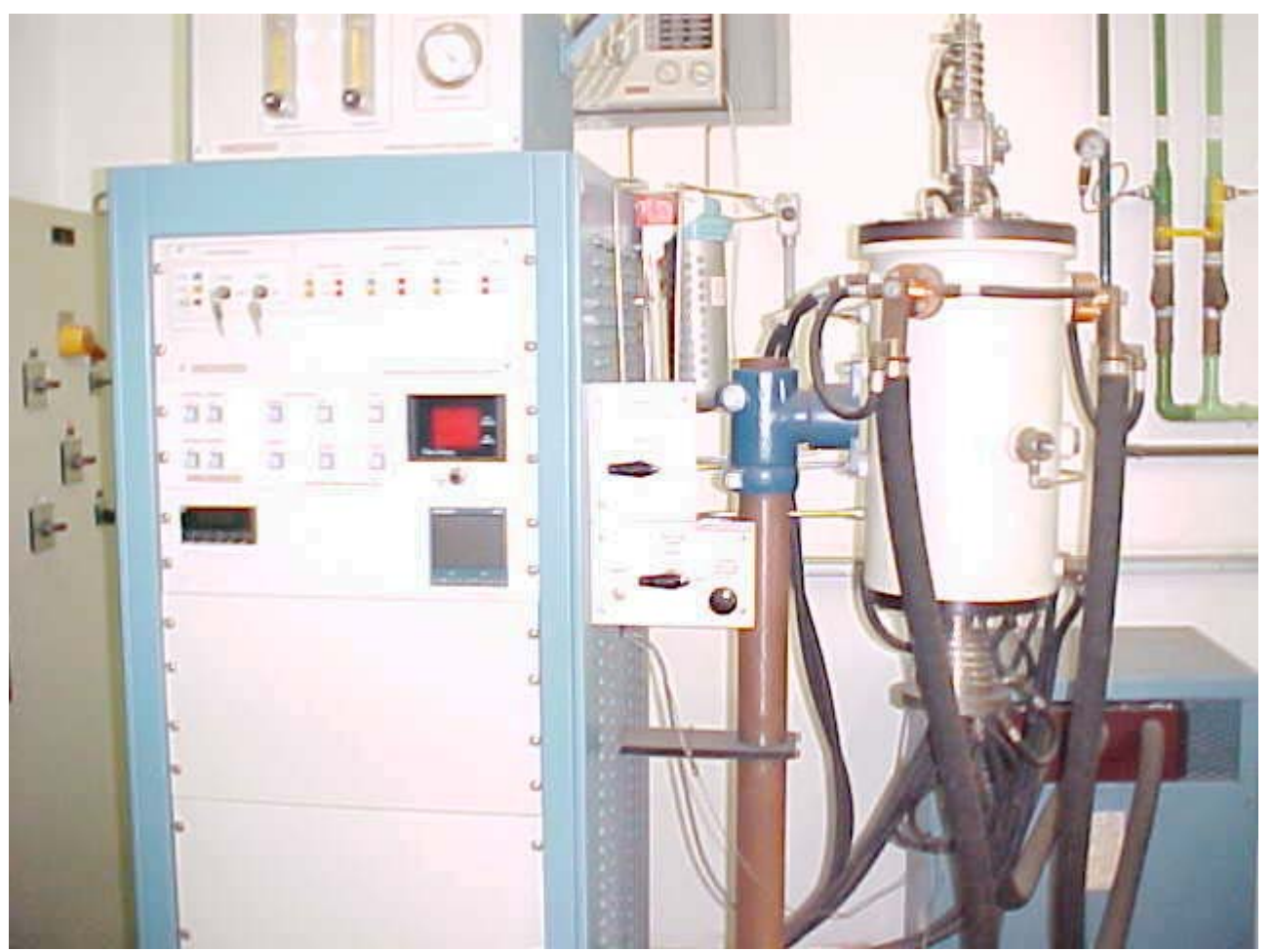

Figura 4.3.3 - Forno elétrico de atmosfera controlada utilizado nos ensaios.

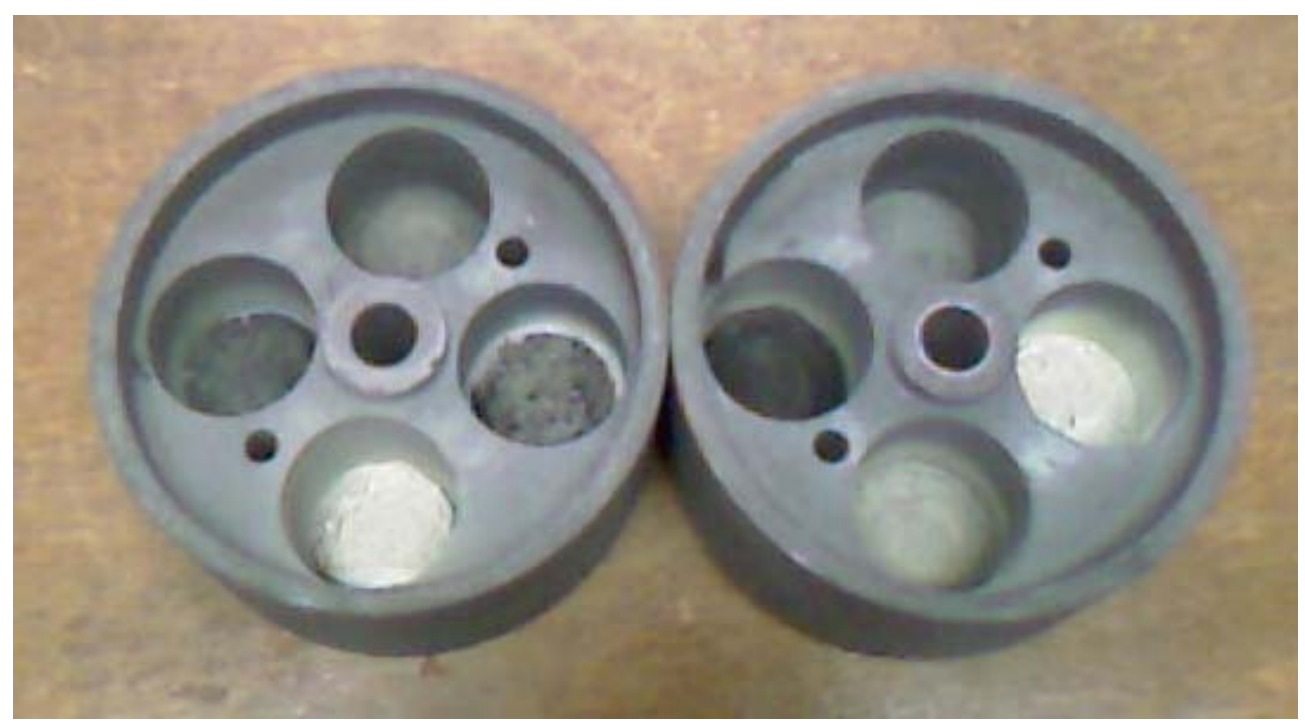

Figura 4.3.4 - Cadinhos de grafite contendo as amostras em seu interior após o ensaio de redução.

As amostras, após o ensaio de redução (figura 4.3.4), foram caracterizadas por difração de raios $X$ a fim de identificar a presença de $\mathrm{SiC}$ e suas fases por equipamento de análise por difração de raios $X$ com monocromador, fendas: $12^{\circ} ; 12^{\circ}$, 0,3 - Tensão de $40 \mathrm{kV}$ - corrente de $20 \mathrm{~A}$ - velocidade contínua $2 \% \mathrm{~min}$ - passo $0,002^{\circ}$ - tubo de Cuka. 


\section{RESULTADOS E DISCUSSÃO}

A redução carbotérmica da sílica envolve a formação de produtos gasosos como o $\mathrm{CO}$ e o $\mathrm{SiO}$, o que implica, principalmente, em perda de massa durante a reação de sintetização do carboneto de silício, não deixando de mencionar, também aquela relativa aos reagentes ou precursores como matéria volátil apresentados na tabela 4.1.2.

As reações apresentaram fonte de carbono suficiente para que toda a sílica fosse consumida, uma vez que, foram atendidas as condições termodinâmicas das reações de (1) a (5).

As amostras foram dispostas no cadinho sem compactação, objetivando maior produção de SiC, como foi comprovado por Chen S. e Lin C. (1997) em seu trabalho, que comparou essa condição com a compactada, obtendo maior taxa de conversão dos produtos sílica e grafite em SiC para sem compactação a uma temperatura de $1.500^{\circ} \mathrm{C}$, demonstrando que o processo de redução ocorre no sistema gás-sólido, implicando na necessidade de se ter vazios para se obter o melhores resultados de produção do SiC.

Analisar, inicialmente os resultados pela perda de massa ao final do ensaio, tem o objetivo de determinar qualitativamente, indicação da possibilidade da existência da reação de redução, bem como também da reatividade dos redutores. A tabela 5.1 indica os valores de massa após o ensaio de redução.

A tabela 5.2 apresenta percentualmente os dados de perda de massa para cada um dos 5 tipos de redutores por temperatura, obtidos a partir das tabela $4.3 .1 \mathrm{e}$ 5.2 que apresentam, respectivamente, as massas iniciais e finais do ensaio.

Tabela 5.1 - Massa final de amostra para cada uma das temperaturas dos ensaios.

Massa Final $(\mathrm{g})$ por Ensaio

\begin{tabular}{cccc}
\hline Redutor & Mf 1550 & Mf 1600 & Mf 1650 \\
\hline \hline GF & 0.502 & 0.530 & 0.450 \\
TF & 0.630 & 0.655 & 0.639 \\
CV & 0.310 & 0.747 & 0.337 \\
CQ & 0.465 & 0.801 & 0.533 \\
NF & 0.530 & 0.886 & 0.596 \\
\hline
\end{tabular}


Tabela 5.2 - Perda de massa em porcentagem por redutor, temperatura e valor médio.

\begin{tabular}{ccccc}
\hline Redutor/Temp & $1550^{\circ} \mathrm{C}$ & $1600^{\circ} \mathrm{C}$ & $1650^{\circ} \mathrm{C}$ & Media \\
\hline \hline TF & $74.8 \%$ & $74.3 \%$ & $74.4 \%$ & $74.4 \%$ \\
CV & $74.2 \%$ & $70.1 \%$ & $70.4 \%$ & $70.4 \%$ \\
CQ & $68.8 \%$ & $68.1 \%$ & $67.9 \%$ & $68.1 \%$ \\
GF & $78.6 \%$ & $79.0 \%$ & $81.3 \%$ & $79.0 \%$ \\
NF & $68.8 \%$ & $64.6 \%$ & $65.9 \%$ & $65.9 \%$ \\
\hline
\end{tabular}

Da tabela 5.2 podemos depreender que a perda de massa para as três temperaturas ensaiadas é aproximadamente constante para quatro dos redutores, não ocorrendo o mesmo para o grafite (GF). Este fato deve ser resultado de uma maior reatividade do GF.

Utilizando-se dos teores de carbono fixo, matéria volátil, umidade e cinzas de cada um dos redutores descritos na tabela 4.1.2 e efetuando-se o cálculo estequiométrico da perda de massa com base na reação de redução (1), obtém-se os valores de perda de massa ideais descritos na tabela 5.3 a seguir. Na mesma tabela também são apresentados os valores médios de perda de massa calculados a partir dos valores da tabela 5.2 para as três temperaturas dos ensaios $\left(1.550^{\circ} \mathrm{C}\right.$, $1.600^{\circ} \mathrm{C}$ e $\left.1.650^{\circ} \mathrm{C}\right)$

Tabela 5.3 - Perda de massa teórico em porcentagem, por redutor e valor médio real encontrado.

\begin{tabular}{ccc}
\hline Redutor & \multicolumn{2}{c}{ Valor Teórico } \\
\hline \hline TF & $62.90 \%$ & $74.44 \%$ \\
CV & $62.03 \%$ & $70.44 \%$ \\
CQ & $59.15 \%$ & $68.09 \%$ \\
GF & $58.48 \%$ & $78.97 \%$ \\
NF & $58.46 \%$ & $65.94 \%$ \\
\hline
\end{tabular}

Observa-se que, todos os valores médios encontrados estão acima dos valores teóricos calculados a partir da reação de redução da sílica (1), com base nos dados da tabela 4.3.1, e também da perda de massa estequiométrica para a reação de redução da sílica (1) que é de $58,28 \%$. Isto significa que uma outra reação de perda de massa ocorre além da considerada. Tal reação é possivelmente a formação do SiO com sua condensação nas superfícies frias do sistema. 
Observa-se também que, o maior valor de perda de massa foi encontrado para o grafite, e de forma oposta, o seu valor ideal da perda de massa apresenta-se entre os menores, como se destaca dos dados encontrados para o grafite apresentados na tabela 5.3 e no gráfico da figura 5.1 .

Como observado na figura 4.3.4 nota-se a presença de $\beta$-SiC, caracterizado pela cor verde clara, depositado na parede do cadinho, acima do nível das amostras que deve se resultado da reação do $\mathrm{SiO}$ condensado com o $\mathrm{C}$ do cadinho corroborando com análises anteriores.

Como o objetivo do trabalho é determinar se há ou não a formação do SiC preocupou-se apenas com a coleta da amostra que apresentava-se solta e não aquela aderida na parede do cadinho, a fim de ser evitado a contaminação da amostra pelo grafite, elemento constituinte do cadinho.

Isto explica, em parte, a grande diferença entre os valores ideais (Balanço de Massa) e os encontrados apresentados na tabela 5.3, para todos os redutores e de forma mais notória para o grafite.

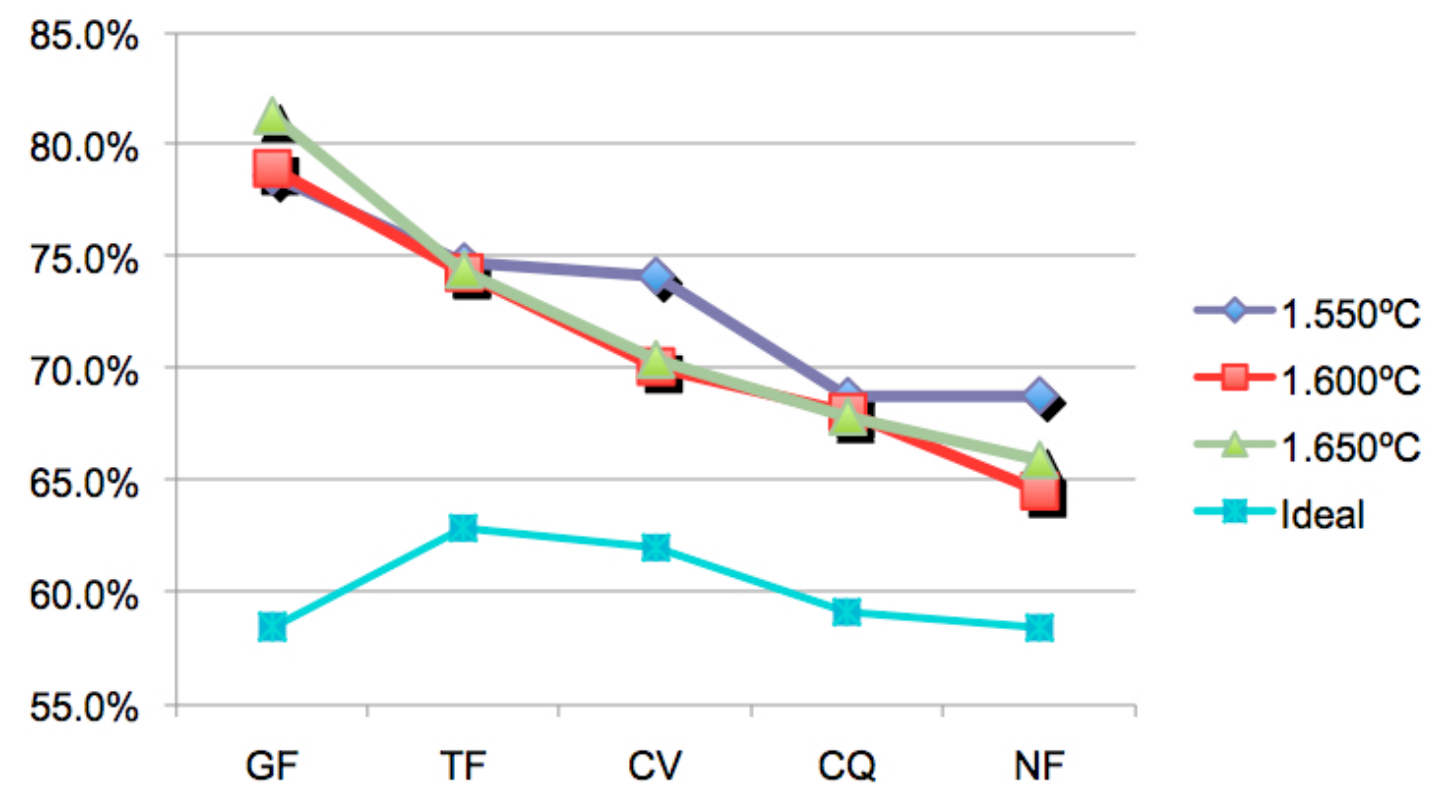

Figura 5.1 - Variação de perda de massa após a reação de redução para cada fonte de carbono e temperatura do ensaio realizada, comparando-se com aquela obtida de forma ideal calculada a partir do carbono fixo, umidade e matéria volátil de cada um dos redutores ou fontes de carbono.

Para o caso essa diferença deve estar relacionada com a reatividade do grafite com a sílica e a mesma estar variando com a temperatura. Pode-se supor ainda que, haja um maior tempo de duração da equação (1) definida como estágio 
inicial no item 1.3, e com isso o volume dos gases $\mathrm{SiO}$ e $\mathrm{CO}$ produzidos serem maiores. Nesta condição uma parte dos gases é arrastada pelo fluxo de argônio sem reagir, e outra parte permanece produzindo o $\mathrm{SiC}$ consumindo o restante da sílica e o carbono da massa inicial.

Nas figuras 5.4 e 5.5 podemos, aparentemente, observar em maior quantidade do que para os outros redutores, a presença de "whiskers" ou pequenas fibras de SiC que, segundo Lin, Y.J., Tsang, C. P. (2003), sua formação só pode ser explicada a partir da reação gás-gás $\left(\mathrm{SiO}_{(\mathrm{g})}+3 \mathrm{CO}_{(\mathrm{g})} \rightarrow \mathrm{SiC}_{(\mathrm{s})}+2 \mathrm{CO}_{2(\mathrm{~g})}\right)$ pois sua morfologia é totalmente diferente daquela da fonte do carbono, o que pode vir a confirmar a suposição feita no parágrafo anterior.

Como os resultados para o grafite apresentam-se recorrentes e ainda de forma crescente com o aumento da temperatura, entende-se a existência de outros fatores que merecem estudo, porém fora do escopo deste trabalho.

Os resultados do ensaio de difração de raios- $X$ revelam a presença de carboneto de silício $\beta$ nas 15 amostras produzidas. Essa identificação é possível a partir da análise dos dados por programa específico denominado "MATCH", que utiliza-se de um banco de dados de referência de difração disponibilizado por "International Union Crystallography (IUCr) Journals", "Crystallography Open Database (COD)" e American Mineralogist Crystal Structure Database (AMCSD).

Esses bancos de dados de referência contém os padrões de difração para materiais em pó, com cerca de 7.300 diferentes tipos de entrada de dados, além do necessário para análise semi-quantitativa (SILVA et al., 2001).

Tem-se também auxiliando nessa identificação dos padrões aqueles encontrados em Chen et al., 1998; Mothé et al., 2002; Chen et al., 2000; Lin et al., 2003; Cattamanchi et al., 1998 e Agarwal et al., 1998.

Na figura 5.2 a seguir, são apresentados os padrões de difração de raios-X dos produtos da redução da sílica para os cinco redutores, ou sejam, turfa (TF), carvão vegetal $(\mathrm{CV})$, coque (CQ), grafite (GF) e negro de fumo (NF), nas temperaturas do experimento de $1550{ }^{\circ} \mathrm{C}, 1600{ }^{\circ} \mathrm{C}$ e $1650{ }^{\circ} \mathrm{C}$, a fim de identificar os constituintes e suas fases. 

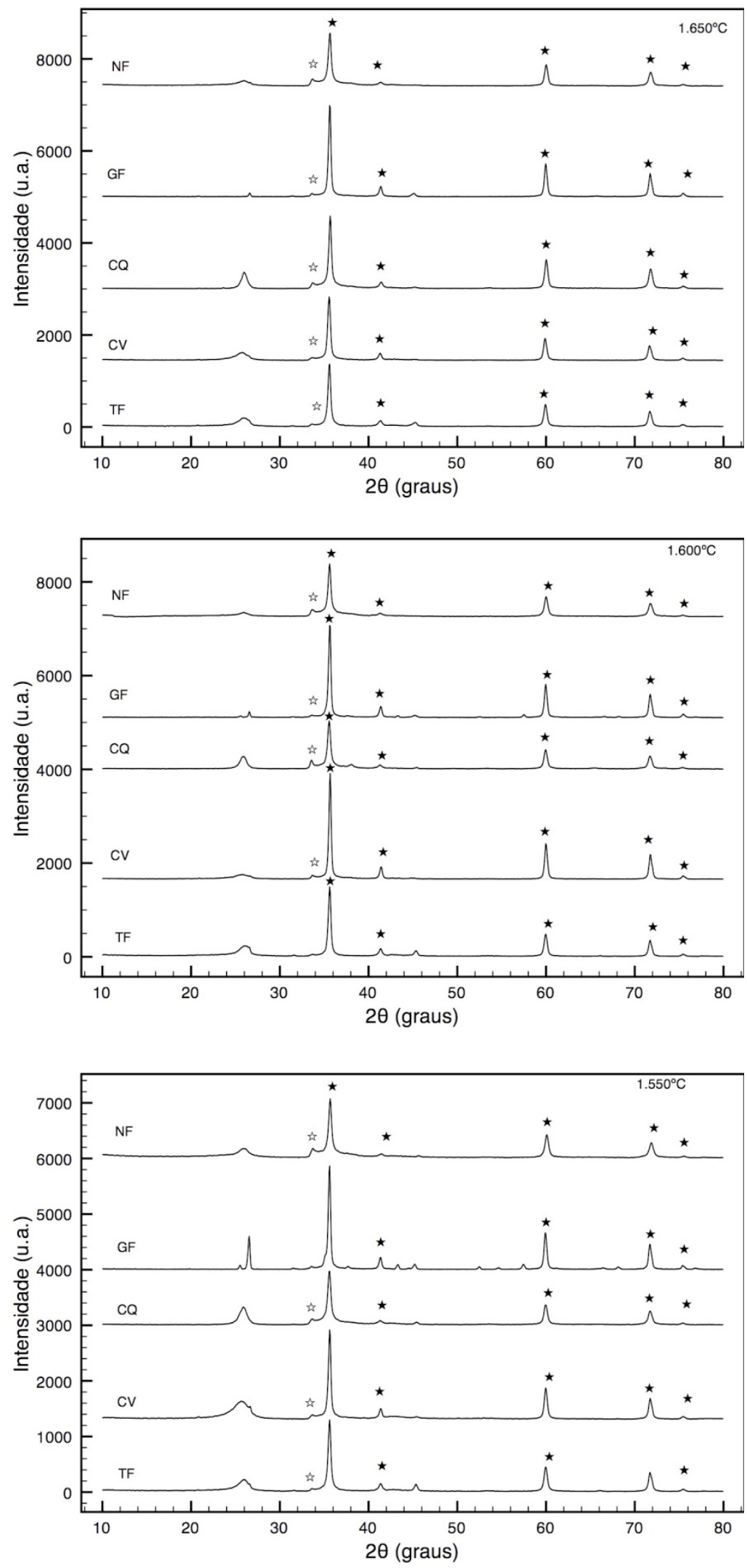

Figura 5.2 - Espectros de difração para os produtos de reação para o redutor negro de fumo (NF), grafite (GF), Coque (CQ), carvão vegetal (CV) e turfa (TF) nas temperaturas de $1550^{\circ} \mathrm{C}, 1600^{\circ} \mathrm{C}$ e $1650^{\circ} \mathrm{C}$. (化 $\mathrm{SiC}-\alpha$; $\star \mathrm{SiC}-\beta$ ). 
É possível identificar a fase $\beta$ e a fase $\alpha$ do carboneto de silício nas 15 amostras como referido anteriormente, porém para os ângulos de difração entre $20^{\circ}$ e $30^{\circ}$ as fases apresentadas não estão claras. Observa-se que, com o aumento da temperatura em que o ensaio é realizado as fases entre esses ângulos tendem a desaparecer, como é mais evidente para o caso do negro de fumo (NF), ou seja, evidencia-se que, trata-se de reagentes ou precursores que estão sendo consumidos com o aumento da temperatura em que o ensaio é realizado ou em que se processa a reação de redução.

A fim de melhor esclarecer, a figura 5.3 apresenta o ensaio de difração de raios-X para as 3 temperaturas do experimento, que tem o negro de fumo (NF) como redutor, aquecidas a $800^{\circ} \mathrm{C}$ ao ar, por 4 horas, para retirar todo o carbono residual. Desta forma é possível afirmar que os elementos que não foram identificados na figura 5.2 são aqueles pertencentes aos reagentes, ou seja, em sua maioria as fases da sílica e carbono, pois na figura 5.3 não se observa nenhuma fase após a queima a não ser as pertencentes ao carboneto de silício, o que indica que deve existir alguma das fases de sílica, mas em quantidades muito baixa.

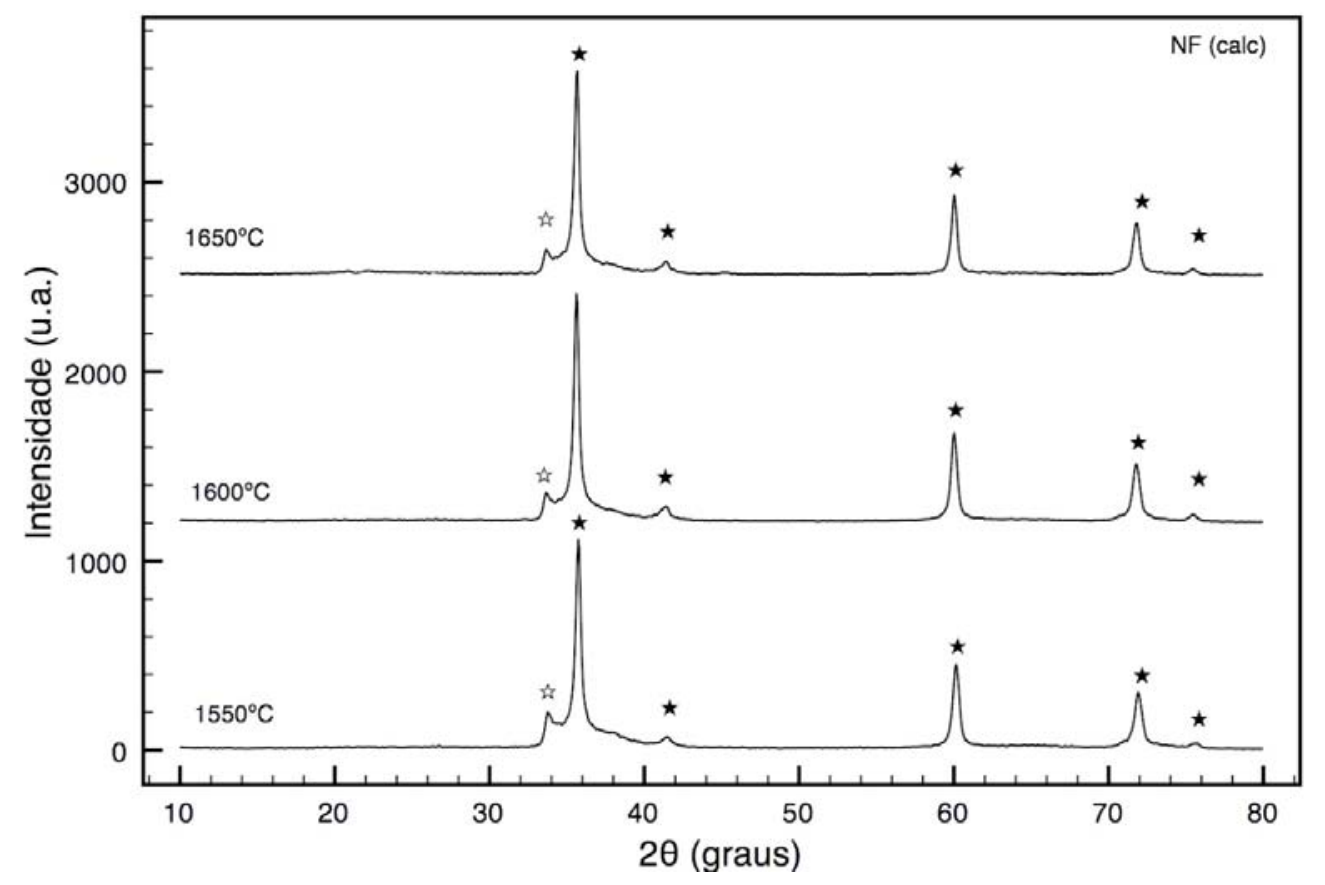

Figura 5.3 - Espectros de difração para os produtos de reação a partir do negro de fumo (NF) após queima a $800^{\circ} \mathrm{C}$ por 4 horas. ( $\downarrow \mathrm{SiC}-\alpha$; $\star \mathrm{SiC}-\beta$ ).

A observação por microscopia eletrônica de varredura (MEV) dos produtos ou SiC formado tem por objetivo verificar sua morfologia compará-la, com o que 
apresenta a literatura e utilizando-se de analise por energia dispersiva de raios $X$ constatar sua composição como se apresenta nas figuras 5.4 e 5.5 a seguir.

$1600^{\circ} \mathrm{C}$
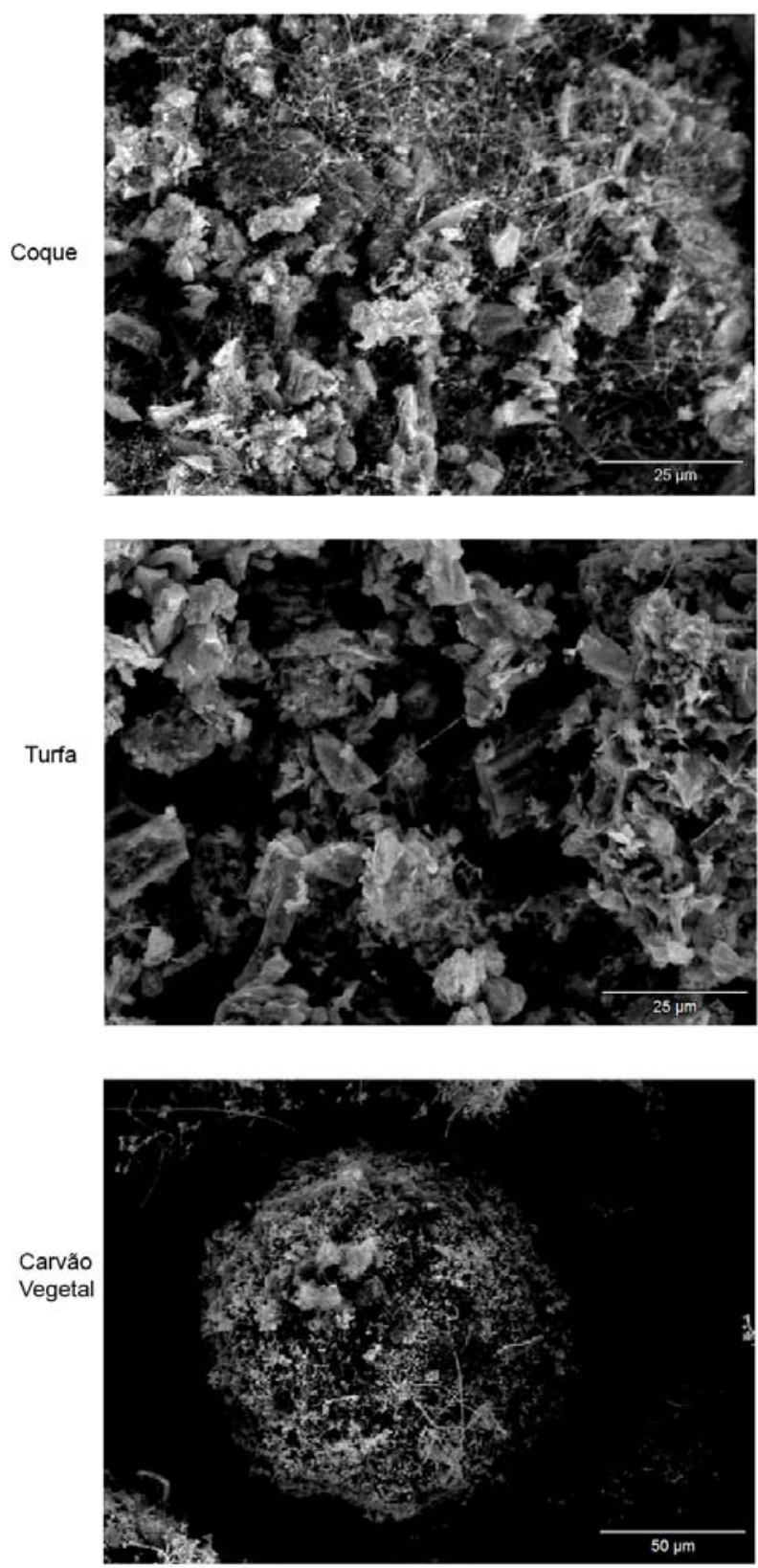

$1650^{\circ} \mathrm{C}$
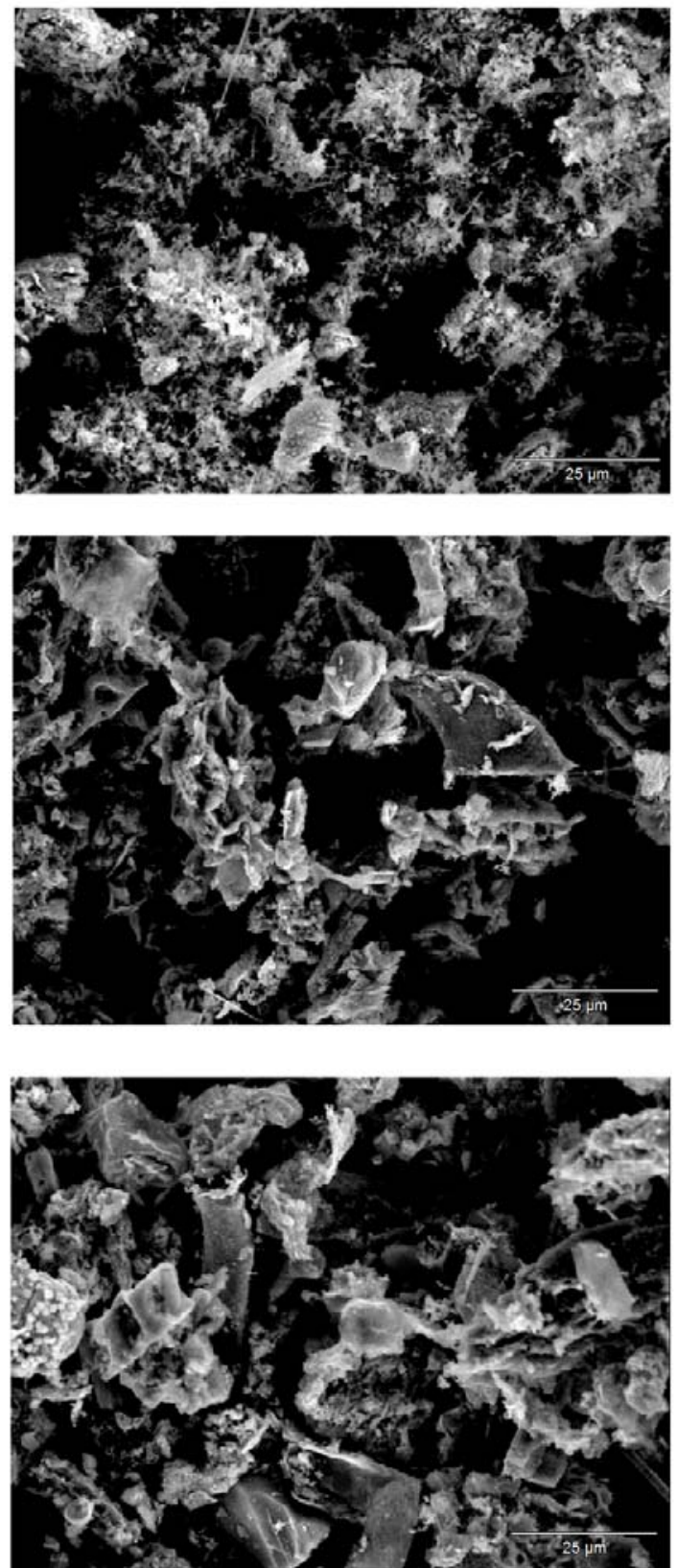

Figura 5.4 - Imagem de elétrons secundários dos produtos de reação para cada um dos redutores utilizados.

Na figura 5.4 observa-se uma característica específica do carboneto de silício que é o de apresentar filamentos ou whiskers junto a partículas de mesma composição. Isto fica mais evidente para o grafite ma figura 5.5 a seguir que, segundo Silva, P.C; Figueiredo, J.L (2001) e como já mencionado anteriormente, é 
uma das formas de precipitação, do SiC resultante de reações (gás-gás) no estágio de propagação, além da característica lamelar dessas partículas.

Figura 5.5 - Imagem de elétrons secundários dos produtos de reação para o negro de

$1.600^{\circ} \mathrm{C}$
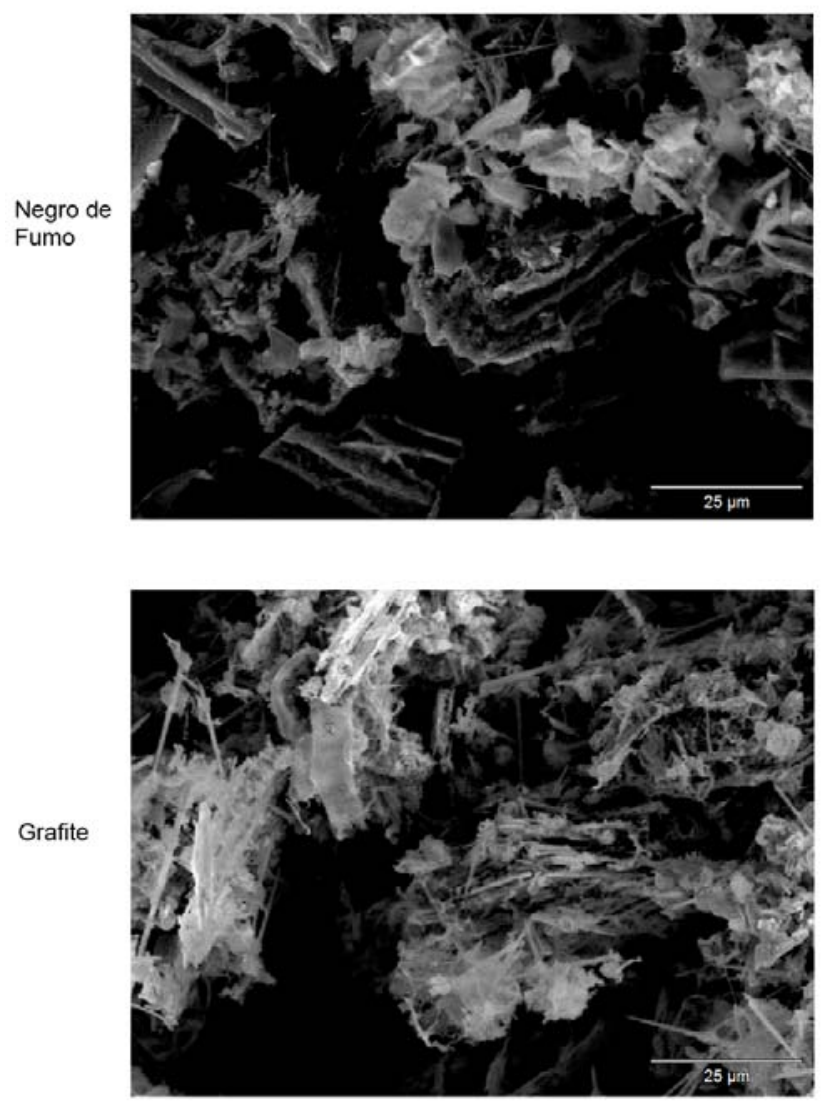

fumo e grafite. $1.650^{\circ} \mathrm{C}$
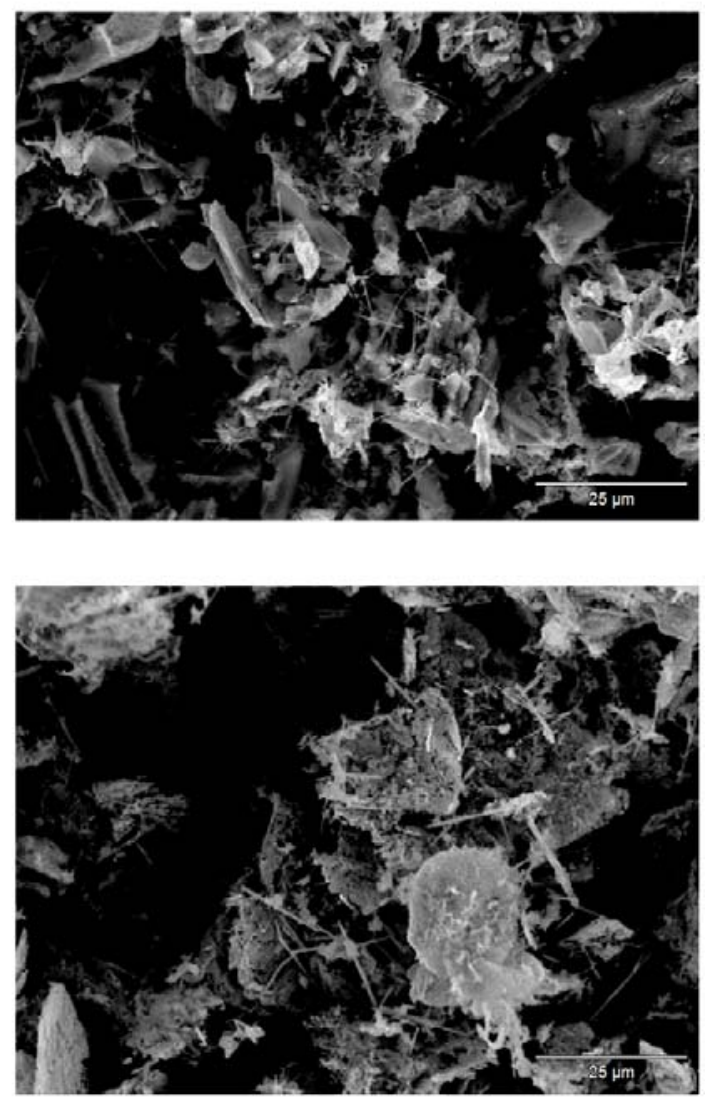

$\mathrm{Na}$ figura 5.5 pode-se observar de forma mais evidente a presença dos filamentos ou whiskers junto a partículas de mesma composição tanto para o negro de fumo como para o grafite, porém de forma mais intensa para este.

Sujirote,K. e Leangsuwan, P. (2003), explicam que, a presença de ferro aumenta formação dos whiskers, e pelo já exposto, para melhor concluir, seriam necessários análises químicas dos elementos presentes nos reagentes "in natura" e após calcinação, uma vez que o rendimento da redução carbotérmica da sílica é muito sensível a presença de fases gasosas, medir a superfície específica dos reagentes e produtos e por fim repetir os ensaios de caracterização deste trabalho. 

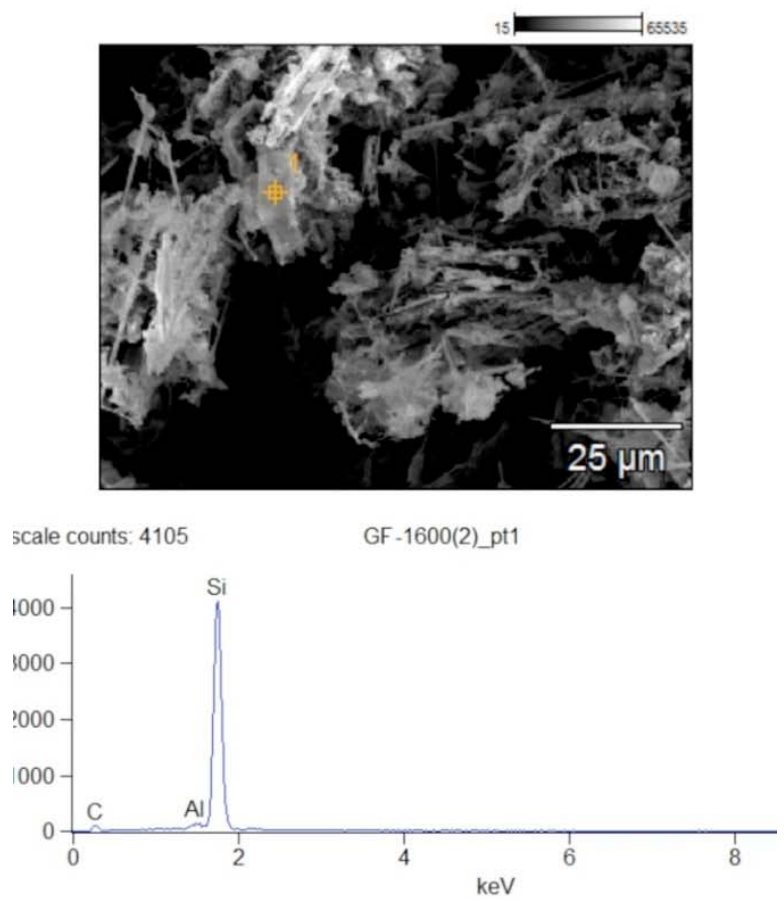

TF-1600(2)
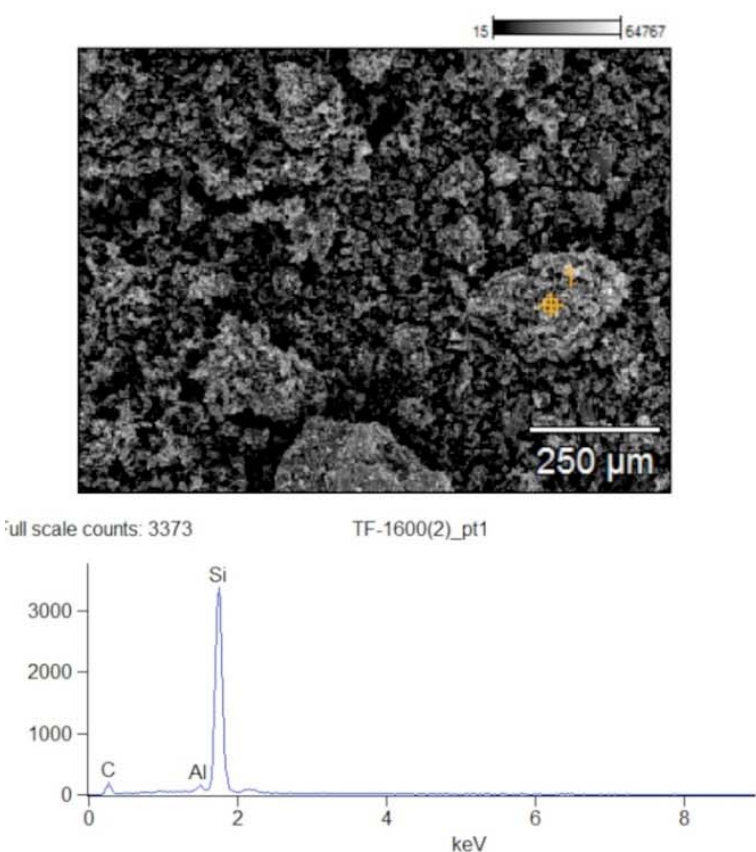

Figura 5.6 - Imagens obtidas por MEV com os elementos presentes no ponto em destaque de cor laranja, para o redutor grafite (GF) e turfa (TF)

A figura 5.6 apresenta os elementos detectados por espectroscopia de dispersão de raios $X$ existentes nas regiões marcadas em laranja para evidenciar a presença do carboneto de silício para o redutor grafite (GF) e da mesma forma para a turfa (TF). O mesmo ensaio é realizado para os outros redutores onde é evidenciado o mesmo resultado, ou seja, a presença de carboneto de silício. 


\section{CONCLUSÕES.}

- Os resultados para os redutores convencionais na reação carbotérmica da sílica são os mesmos que o encontrado na utilização da Turfa ou solo orgânico como redutor, ou seja, todos são adequados para a obtenção do carboneto de silício.

- Não foi possível determinar diferenças entre os redutores com a abordagem utilizada. 


\section{REFERÊNCIAS BIBLIOGRÁFICAS}

ABNT. Norma técnica NBR 8112. Rio de Janeiro. 1983.

AGARWAL A.; U. PAL. Influence of Pellet Composition and Structure on Carbothermic Reduction of Silica. Metalurgical and Materials Transactions B, v. 30B, p. 295-306, April 1999

BAILAR, J. C.; EMELÉUS, H. J.; NYHOLM, Sir RONALD. Comprehensive inorganic chemistry. Pergamon Press Ltd. $1^{\text {st }}$ Edition, v. 1, p. 1419-1423, 1973

BRITO, J. O. Princípios de Produção e Utilização de Carvão Vegetal de Madeira. Scientia Forestalis: Instituto de Pesquisas e Estudos Florestais, n. 9 p. 1-19, Maio 1990.

CATTAMANCHI, RASIT K.S.I.V. Synthesis of Beta Silicon Carbide Powders Using Carbon Coated Fumed Silica. Journal of Materials Science, v. 33, p. 2537-2549, 1998.

CHAIRA D.; MISHRA B.; SANGAL, S. Synthesis and characterization of silicon carbide by reaction milling in a dual-drive planetary mill. Materials Science and Engineering A, v. 460-461, p. 111-120, 2007.

CHEN, C.Y.; LIN, C.I.; CHEN, S.H. Kinetics of synthesis of silicon Carbide by carbothermal reduction of silicon dioxide. British Ceramic Transactions, v. 99, n. 2, p. $57-62,2000$.

CHEN, SEM-HUA; LIN, CHUN-I. Efect of contact area on synthesis of silicon carbide through carbothermal reduction of silicon dioxide. Journal of Materials Science Letters, v. 16, p. 702-704, 1997.

CHEN, SEM-HUA; LIN, CHUN-I. Phase Transformations in silicon-containing solid sample during synthesis of silicon carbided through carbothermal reduction of silicon dioxide. Journal of Materials Science Letters, v. 17, p. 657-659, 1998.

FRANCHI, JOSÉ GUILHERME; SÍGOLO, JOEL BARBUJIANI; LIMA, JOSÉ RENATO BATISTA DE. Turfa Utilizada na Recuperação Ambiental de Áreas Mineradas: metodologia para avaliação laboratorial. Revista Brasileira de Geociências, v. 33, p. 255-262, 2003.

GUPTA, G. S.; VASANTH K. P.; RUDOLPH; GUPTA, M. Heat-Transfer model for the Acheson process. Metallurgical and Materials Transactions A, v. 32A, p. 13011308, June 2001.

HAENEL, MATTHIAS W. Recent Progress in coal structure research. Fuel, v. 71, p. 1211-1223, November 1992.

HARRIS, PAUL. Silicon Carbide \& More. Suply News, IL, USA, n. 23, p. 1, 2008.

IZHEVSKYI, V.A.; GENOVA, L.A.; BRESSIANI, J.C.; BRESSIANI, A.H.A. Carboneto de Silício, Estrutura, Propriedades e Processamento Cerâmica, v. 46, n. 297, São Paulo, Jan./Feb./Mar. 2000. 
LIN, YUNG-JEN; TSANG, CHIA-PING. The Effects of Starting Precursors On The Carbothermal Synthesis of SiC Powders. Ceramic International, v. 29, p. 69-75, 2003.

METALS HANDBOOK, Alloy Phase Diagram, v. 3.

MICHAEL SHUR, SERGEY RUMYANTSEV, MICHAEL LEVINSHTEIN. SiC Materials and Devices: Volume 1. Singapore: World Scientific Publishing Co. Pte., p. 1, 2006.

NASSAU, KURT. Synthetic Moissanite: a new man-made jewel. Current Science, v. 79, n. 11, Dec. 2000.

PERIC, J. RADIC; PANTELIC. Thermodynamic modeling of silicon carbide synthesis in thermal plasma. Journal of Thermal Anlysis and Calorimetry, v. 72, p. 35-45, 2003.

ROMERO, F.J. NARCISO; REINOSO, F. RODRÍGUEZ; DIEZ, M.A.. Influence of Carbon Material on Synthesis of Silicon Carbide. Carbon, v. 37, p. 1771-1778, 1999.

SATAPHATY, L.N.; RAMESH, P.D.; AGRAWAL, DINESH; ROY, RUSTUM. Microwave Synthesis of Phase-Pure, Fine Silicon Carbide Powder. Material Research Bulletin, v. 40, p. 1871-1882, 2005.

SELVAM, A.; NAIR, N. G.; SINGH, PARAMANAND. Synthesis and characterization of $\mathrm{SiC}$ whiskers from coconut shells. Journal of Materials Science Letters, v.17, p. 57-60, 1998.

SILVA, A.J.C.. Caracterização tecnológica do quartzito friável de Itutinga - MG, com vista à produção de carboneto de silício (SiC). Dissertação de Mestrado. EP ESCOLA POLITÉCNICA - USP, São Paulo, 2003.

SILVA, D. A.; BRITO, J.O.. Estudo Comparativo da Carbonização de Três Origens de Turfas em Relação à Madeira de Eucalyptus Grandis. Scientia Forestalis: Instituto de Pesquisas e Estudos Florestais, n. 36, p. 21-26, 1987.

SILVA, P.C; FIGUEIREDO, J.L. Production of $\mathrm{SiC}$ and $\mathrm{Si}_{3} \mathrm{~N}_{4}$ whiskers in $\mathrm{C}+\mathrm{SiO}_{2}$ solid mixtures. Materials Chemistry and Physics, n. 72, p. 326-331, 2001.

SOMIYA, SHIGEYUKI; INOMATA, YOSHIZO. Silicon Carbide Ceramics-2. London and New York: Elsevier Science Publishers Ltd, 1991, p. 52-54, cap. 4 - Onoda silicon Carbide Powder.

SUJIROTE,K.; LEANGSUWAN, P.. Silicon Carbide Formation From Pretreated Rice Husks. Journal of Materials Science, v. 38, p. 4739-4744, 2003.

The Materials Science SiC, disponível em: www.ifm.liu.se/Matephys/ new_page/research/SiC(s)/index.html (17/06/2008).

WISSLER, MATHIS. Graphite and Carbon Powders for Electrochemical Applications. Journal of Power Sources, v. 156, p. 142-150, 2006. 